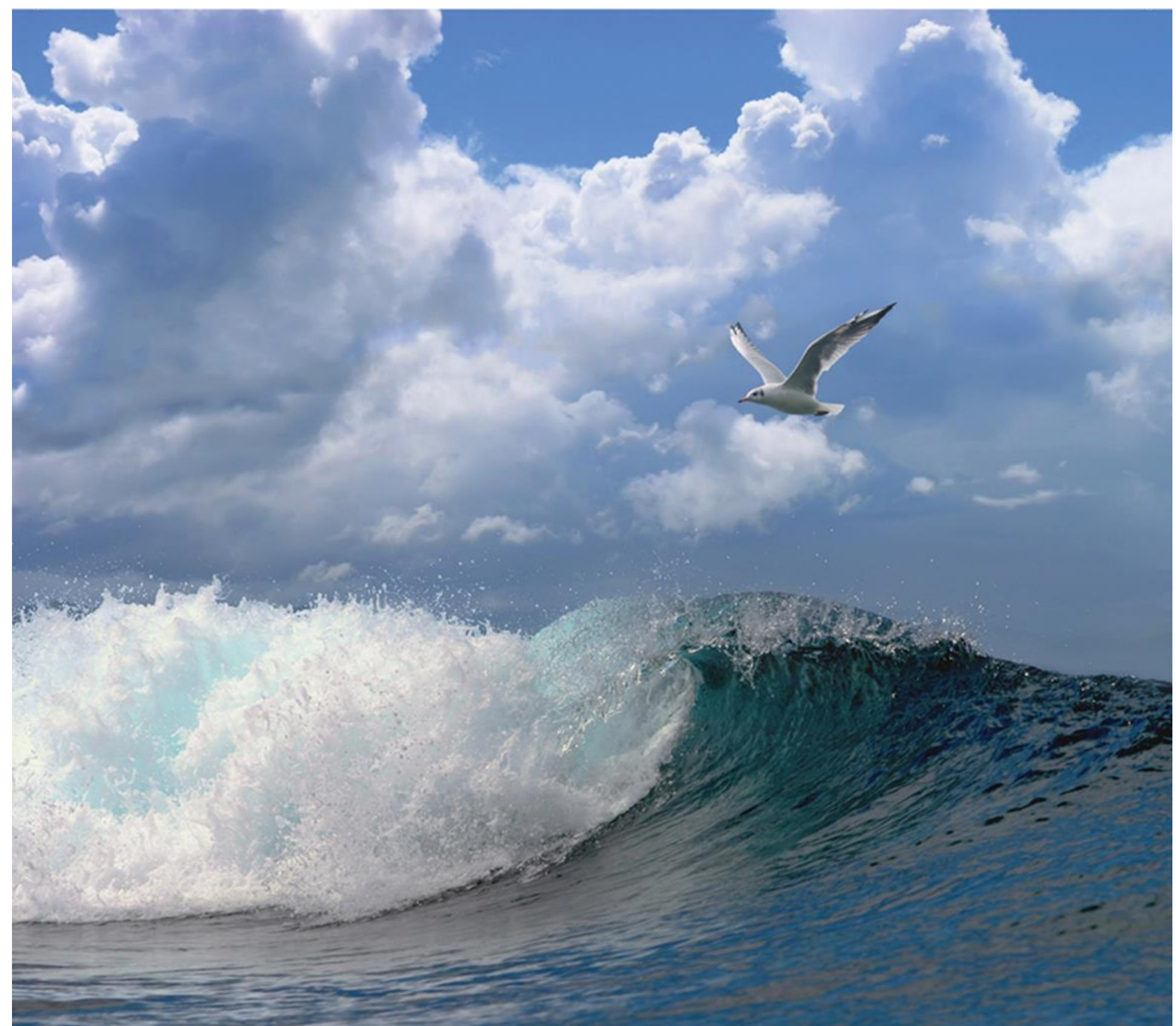

\title{
Paai- en opgroeigebieden voor vis in en rond Marker Wadden
}




\section{Paai- en opgroeigebieden voor vis in en rond Marker Wadden}

Auteur(s): Joep J. De Leeuw ${ }^{1}$, Joey Volwater ${ }^{1}$, Olvin A. van Keeken ${ }^{1}$, Jelger Elings ${ }^{1}$ \& Casper H.A. van Leeuwen $^{2}$

${ }^{1}$ Wageningen Marine Research (WMR)

${ }^{2}$ Nederlands Instituut voor Ecologie (NIOO-KNAW)

Dit onderzoek is uitgevoerd door Wageningen Marine Research en gesubsidieerd door KIMA /EcoShape en het WUR Kennisbasisprogramma: KB36 Biodiversiteit in een Natuurinclusieve Samenleving (projectnummer KB36003-015) - dat wordt ondersteund door het Ministerie van Landbouw, Natuur en Voedselkwaliteit. 


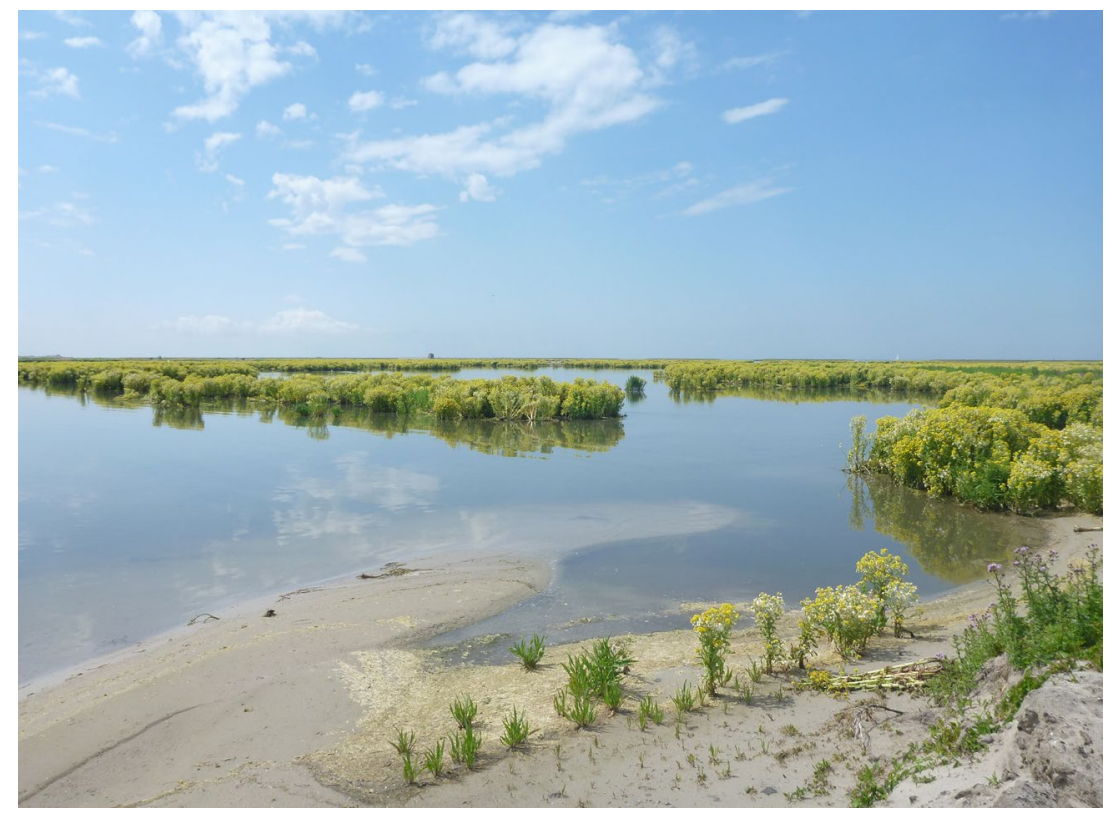

Dit rapport is gratis te downloaden van https://doi.org/10.18174/563170

Wageningen Marine Research verstrekt geen gedrukte exemplaren van rapporten.

Wageningen Marine Research is ISO 9001:2015 gecertificeerd.

Foto omslag: Joep de Leeuw

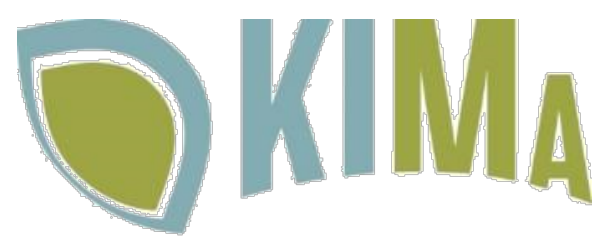

\section{(c) Wageningen Marine Research}

Wageningen Marine Research, instituut binnen de rechtspersoon Stichting

Wageningen Research, hierbij

vertegenwoordigd door

Dr.ir. J.T. Dijkman, Managing director

KvK nr. 09098104,

WMR BTW nr. NL 8113.83.696.B16.

Code BIC/SWIFT address: RABONL2U

IBAN code: NL 73 RABO 0373599285
Wageningen Marine Research aanvaardt geen aansprakelijkheid voor gevolgschade, noch voor schade welke voortvloeit uit toepassingen van de resultaten van werkzaamheden of andere gegevens verkregen van Wageningen Marine Research. Opdrachtgever vrijwaart Wageningen Marine Research van aanspraken van derden in verband met deze toepassing.

Alle rechten voorbehouden. Niets uit deze uitgave mag weergegeven en/of gepubliceerd worden, gefotokopieerd of op enige andere manier gebruikt worden zonder schriftelijke toestemming van de uitgever of auteur. 


\section{Inhoud}

Samenvatting

$1 \quad$ Inleiding

2 Kennisvraag

$3 \quad$ Methoden

3.1 Paai- en opgroeihabitats Marker Wadden $\quad 8$

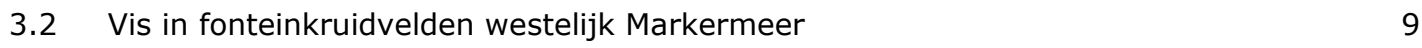

$\begin{array}{ll}3.3 & \text { Zandwinputten rond Marker Wadden } \\ \end{array}$

4 Resultaten $\quad 11$

4.1 Habitats en habitatgebruik jonge vis Marker Wadden 11

4.1.1 Dood hout $\quad 11$

$\begin{array}{lll}4.1 .2 & \text { Steenoever } & 11\end{array}$

$\begin{array}{lll}4.1 .3 & \text { Moerasandijvie } & 12\end{array}$

$\begin{array}{lll}4.1 .4 & \text { Rietoever } & 12\end{array}$

4.1.5 Beschutte zandoever 13

4.1.6 Halfbeschutte zandoever 13

4.1.7 Onbeschutte zandoever (buitenzijde eilanden) 14

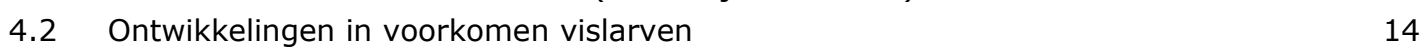

$\begin{array}{lll}4.2 .1 & 2019 & 15\end{array}$

$\begin{array}{lll}4.2 .2 & 2020 & 16\end{array}$

$\begin{array}{lll}4.2 .3 & 2021 & 18\end{array}$

$\begin{array}{lll}4.3 & \text { Effecten van omgevingsvariabelen wind en temperatuur } & 20\end{array}$

\begin{tabular}{ll}
4.4 & Vis in fonteinkruidvelden westelijk Markermeer \\
\hline
\end{tabular}

$\begin{array}{lll}4.5 & \text { Zandwinputten rond Marker Wadden } & 24\end{array}$

$\begin{array}{llr}5 & \text { Conclusies en aanbevelingen } & 27\end{array}$

$\begin{array}{llr}5.1 & \text { Habitats voor paai en opgroei } & 27\end{array}$

$\begin{array}{lll}5.1 .1 & \text { Ontwikkeling soortenrijkdom } & 27\end{array}$

5.1.2 Soortsamenstelling en habitatgebruik jonge vis 28

$\begin{array}{lll}5.1 .3 & \text { Rol Marker Wadden in de jaarcyclus } & 29\end{array}$

$\begin{array}{ll}5.2 & \text { Verwachte ontwikkelingen jonge vis in oeverzones } \\ 5.30\end{array}$

5.3 Effecten Marker Wadden op visstand en vogels Markermeer $\quad 31$

5.4 Potentie Marker Wadden voor vis en vogels: beheer $\quad 34$

$\begin{array}{lll}5.5 & \text { Aanbevelingen } & 35\end{array}$

$\begin{array}{llr}6 & \text { Kwaliteitsborging } & 37\end{array}$

$\begin{array}{lr}\text { Literatuur } & 38\end{array}$

$\begin{array}{lr}\text { Verantwoording } & 40\end{array}$

$\begin{array}{llr}\text { Bijlage } 1 \quad \text { Bemonsteringen 2019-2021 } & 41\end{array}$

$\begin{array}{lll}\text { Bijlage } 2 & \text { Lengteverdelingen per soort } & 43\end{array}$

$\begin{array}{llr}\text { Bijlage } 3 & \text { Groei } & 59\end{array}$ 
Bijlage $4 \quad$ Windrozen

63

Bijlage $5 \quad$ Trintelzand

64 


\section{Samenvatting}

Marker Wadden is een eilandengroep die sinds 2016 aangelegd wordt in het Markermeer. In het kader van het Kennis- en Innovatieprogramma Marker Wadden (KIMA) is onderzocht hoe de nieuw gevormde habitats op en rond Marker Wadden worden benut als paaigebieden en opgroeigebieden voor jonge vis en op die manier bijdragen aan de visproductie en voedselbasis voor visetende watervogels. Dit rapport vormt een achtergronddocument voor het KIMA-syntheserapport 2022 (KIMA, concept 2021) dat het onderzoek in de eerste 5 jaar van het ontstaan van de archipel samenvat.

Voor het onderzoek naar paai- en opgroeigebieden voor vis zijn intensieve visstandbemonsteringen uitgevoerd naar het voorkomen en de abundantie van vislarven en jonge vis in het voorjaar en de zomer (april/mei-september) van 2019 (eerste eiland,) en 2020 en 2021 (alle eilanden). In juni 2020 is tevens eenmaal een bemonstering uitgevoerd in de nieuwe habitats van Trintelzand. Waar mogelijk werd wadend in ondiepe oeverzones bemonsterd met respectievelijk een larvennet, RAVON-net en een broedzegen. Bij instabiele bodems (met name in de eerste periode na aanleg) werd ook vanuit Canadese kano's gevist. In 2020 en 2021 zijn de bemonsteringen in samenwerking met onderzoeksprogramma Natuur in Productie (Nederlands Instituut voor Ecologie, Rijksuniversiteit Groningen en Radboud Universiteit) uitgevoerd. Determinatie van jonge vis gebeurde grotendeels in het veld. Kleine larven werden verzameld op formol voor nadere identificatie in het lab (microscoop). In aanvulling op het onderzoek naar paai- en opgroeigebieden rond de eilanden van Marker Wadden zijn in 2018 in het westelijk Markermeer verschillende bemonsteringsmethoden getest voor het vaststellen van soortsamenstelling van vis in en tussen fonteinkruidvelden, een type habitat dat zich op grote schaal ontwikkelt tussen de eilanden van Marker Wadden en Trintelzand. In augustus 2019 is daarnaast nog het voorkomen van vis in zandwinputten rond Marker Wadden onderzocht.

Belangrijke habitats voor productie van jonge vis zijn ondiepe oeverzones, met name zones met een combinatie van oevervegetatie (riet en moerasandijvie) en onderwatervegetatie (fonteinkruid, aarvederkruid, kranswier), terwijl kale zand- en sliboevers vooralsnog relatief weinig te bieden hebben voor de meeste soorten jonge vis. Trintelzand en Marker Wadden hebben vergelijkbare functies doordat het beschutte gebieden zijn met geleidelijke land-water overgangen zoals die elders in het Markermeer weinig te vinden zijn. Dit heeft meerwaarde als paai- en opgroeigebied voor vele soorten vis. Binnen deze gebieden is er een grote variatie in habitats en ecologische waarde, ook tussen seizoenen en jaren, mede als gevolg van variatie in ontwikkeling van de watertemperatuur in het voorjaar en van wind die fluctuaties in waterpeil veroorzaakt (Marker Wadden zijn "windwadden"). De zandwinputten (met een diepte van 10-30 m) bieden een additioneel type habitat wat door zowel grote vis (met name snoekbaars) als kleine vis (met name spiering en jonge baars) gebruikt wordt. Het gebied bevindt zich nog in een pionierssituatie maar zal zich waarschijnlijk verder ontwikkelen richting een door waterplanten gedomineerde toestand, zowel oevers als de geleidelijke landwaterovergangen als de diepere delen van het meer in de luwte van de eilanden. In bemonsteringen met stortkuil en zegen werd daar een variatie aan jonge vis, inclusief (kleinere) roofvis als jonge snoekbaars en baars aangetroffen.

De belangrijkste conclusie tot dusver is dat geleidelijke land-waterovergangen met flauwe taluds in de luwte van eilanden zorgen voor een mozaïek van vegetatierijke oeverzones voor paaien en ondiepe baaien met ondergedoken vegetatie die van belang zijn voor de productie van jonge vis. Op de schaal van het Markermeer werd de afgelopen jaren echter een zeer lage visstand waargenomen waarbij de aanleg van kale zandoevers op voorheen relatief visrijke stenen oevers, alsmede baggerwerkzaamheden, vermoedelijk een rol van betekenis hebben gespeeld. Het is belangrijk te noteren dat het tot dusver gaat om pionierssituaties die in ontwikkeling zijn. Dit zijn langjarige processen waarbij verschillende vormen van beheer mogelijk zijn die uiteindelijk zullen bepalen welke habitatontwikkeling en welke visproductie gerealiseerd kan worden. 


\section{Inleiding}

In het kader van het Kennis- en Innovatieprogramma Marker Wadden (KIMA) onderzoeken Rijkswaterstaat, Natuurmonumenten, Deltares en EcoShape hoe het ecosysteem van Marker Wadden zich ontwikkelt. Dit programma onder de noemer "Building with Nature" heeft als doel kennis te genereren en te presenteren over bouwen met slib, zandige keringen, ecologie en governance. Binnen het onderdeel "Ecosysteem van waarde" is in de periode 2018-2021 daarbij onder andere de betekenis van de nieuw ontstane habitats rond Marker Wadden voor vis onderzocht door Wageningen Marine Research (WMR) in samenwerking met het Nederlands Instituut voor Ecologie (NIOO-KNAW) vanuit het onderzoeksprogramma 'Natuur in Productie' en met Sportvisserij Nederland (jaarlijkse vismonitoring). Dit rapport vormt een achtergronddocument voor het KIMA-syntheserapport 2022 (KIMA, concept 2021) dat het onderzoek in de eerste 5 jaar van het ontstaan van de archipel samenvat.

Marker Wadden is een eilandengroep die sinds mei 2016 aangelegd wordt in het Markermeer. De eilandengroep bestaat tot dusver uit vijf eilanden, waarvan het noordwestelijke eiland (ook wel het 'eerste eiland' of 'hoofdeiland' genoemd) voor publiek toegankelijk is. Het ontwerp van Marker Wadden is geïnspireerd door de ondiepe verlandingszones zoals die op grote schaal voorkomen in meer natuurlijke grote meren als Vörtsjärv en Peipsi in Estland en Rusland (Van Eerden et al. 2007). Zulke natuurlijke zones met vegetatierijke land-waterovergangen vormen belangrijke paai- en opgroeigebieden voor jonge vis. Het huidige Markermeer kent maar weinig natuurlijke landwaterovergangen - meer dan driekwart van de oevers in het Markermeer is verhard met basaltblokken. Voor een nadere beschrijving van het concept van de aanleg van Marker Wadden en de eerste resultaten wordt verwezen naar KIMA (2021) en Van Leeuwen et al. (2021).

Het onderzoek is uitgevoerd terwijl de aanleg nog in volle gang was. Daarbij is van nieuwe oeverzones van verschillende typen (kale zandoevers, moerasandijvievelden, rietoevers) onderzocht wat deze als paai- en opgroeigebied betekenen voor verschillende soorten vis. Daarbij is ook gekeken naar de ruimtelijke samenhang van mogelijk geschikte biotopen, zoals mate van beschutting en aanwezigheid van fonteinkruidvelden. De betekenis van fonteinkruidvelden voor vis en hoe dit habitat het beste kan worden bemonsterd is in 2018 onderzocht in het westelijk Markermeer waar dit habitattype op grote schaal voorkomt. Daarnaast is in 2019 onderzocht wat de betekenis is van zandwinputten die door de bouw van de eilanden zijn ontstaan rond Marker Wadden. 


\section{Kennisvraag}

Doel van het KIMA-onderzoek is zo goed mogelijk te beschrijven hoe Marker Wadden zich ontwikkelen en hoe er zo natuurlijk mogelijk gebouwd kan worden met gebruik van zand en slib voor een rijke natuur en een verbeterde natuurlijke productie.

De kennisvraag die in dit rapport wordt behandeld gaat om wat de betekenis is van verschillende habitats rond de nieuw gevormde eilanden in de periode 2019-2021 voor paai- en opgroeimogelijkheden van vis; en wat deze nieuwe gebieden op die manier bijdragen aan de visproductie en voedselbasis voor visetende watervogels. 


\section{Methoden}

\subsection{Paai- en opgroeihabitats Marker Wadden}

Het onderzoek aan de habitatkeuze van vis werd aangepast aan de ontwikkelingen; daarbij werden al te dynamische gebieden (waar gebaggerd werd of net opgespoten gebieden) gemeden. In 2018 was de aanleg van het eerste eiland nog in volle gang en is voornamelijk onderzoek uitgevoerd naar vis in de fonteinkruidvelden in het westelijk Markermeer. In 2019 was het hoofdeiland toegankelijk en voldoende gestabiliseerd met enige vegetatieontwikkeling en daardoor geschikt om bemonsteringen uit te voeren. Een groot deel van het eiland bestond toen echter nog uit voor vis ontoegankelijke compartimenten en de bemonsteringen werden voornamelijk uitgevoerd op locaties met ondiepe landwaterovergangen die in verbinding stonden met het open water. In 2020 en 2021 konden daarnaast ook de overige eilanden worden bemonsterd. Het ging hierbij vooral om de ondiepe zones tot maximaal $1.5 \mathrm{~m}$ diep. In november 2020 zijn de compartimenten van het hoofdeiland verbonden met het open water waardoor een aanzienlijk groter ondiep water-gebied toegankelijk werd voor vis. In aanvulling op de visbemonsteringen in de opgroeigebieden gedurende de zomer worden de diepere habitats rond Marker Wadden en sommige oeverzones jaarlijks in mei en september door Sportvisserij Nederland bemonsterd.

Habitattypen zijn gedefinieerd op basis van de begroeiing van de land-waterovergang en/of mate van exponering aan wind en golfslag (beschut/onbeschut) (Figuur 1): (1) moerasandijvie, (2) rietoever, (3) zandoever beschut, (4) zandoever halfbeschut (meer open maar tussen de eilanden), en (5) zandoever onbeschut (buitenzijde van de eilanden).

In 2019 waren de bemonsteringslocaties gericht op rietoevers en moerasandijvievelden met slechts enkele steekproeven bij onbegroeide zandoevers en de reeks dode essenboomstammen met veel zijtakken die als habitatverrijking in de ondiepte ten noordoosten van de haven zijn gedeponeerd. De eerste bemonstering vond plaats halverwege maart waarbij werd bemonsterd met een fijnmazig larvennet ( $25 \mathrm{~cm}$ breed, maaswijdte $0,3 \times 0,3 \mathrm{~mm}$ ). Later in het seizoen werd ook gebruik gemaakt van het RAVON-net (70 cm breed) met een iets grotere maaswijdte $(3 \times 3 \mathrm{~mm}$ ) waarmee iets grotere juveniele vis goed gevangen kon worden. In juli werd naast de twee verschillende schepnetten voor jonge stadia ook een broedzegen (15 meter met zak, maaswijdte $1 \mathrm{~cm}$ gestrekt) gebruikt zodat de inmiddels grotere juveniele vis tegelijkertijd bemonsterd kon worden.

In 2020 was de bemonsteringsopzet meer gestructureerd over de 5 eerder genoemde habitats (naast rietoevers en moerasandijvie zoals in 2019 ook beschutte, halfbeschutte en onbeschutte zandoevers) die inmiddels te bemonsteren waren en bovendien konden meer locaties verspreid over meerdere eilanden worden bemonsterd (Figuur 1). Het aantal bemonsteringslocaties was niet gelijk verdeeld over de verschillende habitattypen: 2 locaties met rietoevers (beide in de haven), 7 met moerasandijvie, 4 met beschutte zandoevers, 3 met halfbeschutte zandoevers en 4 met onbeschutte zandoevers. Naar aanleiding van ervaringen in 2019 waarbij vrijwel geen vislarven in maart en april werden aangetroffen, werd in mei gestart met het bemonsteren van de verschillende habitats. Hierbij werd op alle locaties enkel nog met het larvennet gevist (Bijlage 1). In juni werden alle locaties bemonsterd met zowel het larven- als het RAVON-net, daarnaast werd op locaties die daarvoor geschikt waren gevist met de broedzegen (15 m, zonder zak; een iets lichtere en in slikkige habitats beter hanteerbare zegen dan de broedzegen die in 2019 werd gebruikt). In juli en augustus werden de locaties met het RAVON-net en de broedzegen bemonsterd en in september werd alleen met de broedzegen bemonsterd.

In 2021 was de bemonstering beperkt tot acht bemonsteringslocaties waarbij onbeschutte zandoevers aan de buitenzijde van de eilanden niet meer zijn bemonsterd en voor de 4 overige habitattypen twee locaties werden bemonsterd. Naast de drie hierboven beschreven vistuigen werd in 2021 ook gebruik 
gemaakt van een larvenzegen ( 3 meter, maaswijdte $3 \times 3 \mathrm{~mm}$ ). In juli en augustus werden de locaties enkel nog met het RAVON-net en de $10-\mathrm{m}$ broedzegen bemonsterd.

Voor het visstandonderzoek, uitgevoerd door Sportvisserij Nederland rond Marker Wadden, is gebruik gemaakt van de volgende vistuigen (Van Emmerik 2020a, 2020b, 2021):

- broedkor, een sleepnet met een kleine maaswijdte, vangt vis op de bodem;

- broedzegen, een zegen met een kleine maaswijdte, vist over de hele waterkolom tot 2 meter diep;

- elektrovisapparaat, in ondiepe oevers met structuren zoals stenen of waterplanten.

De broedkor en de broedzegen worden alleen ingezet op plekken waar geen obstakels aanwezig zijn, om zo beschadigingen aan de netten te voorkomen .

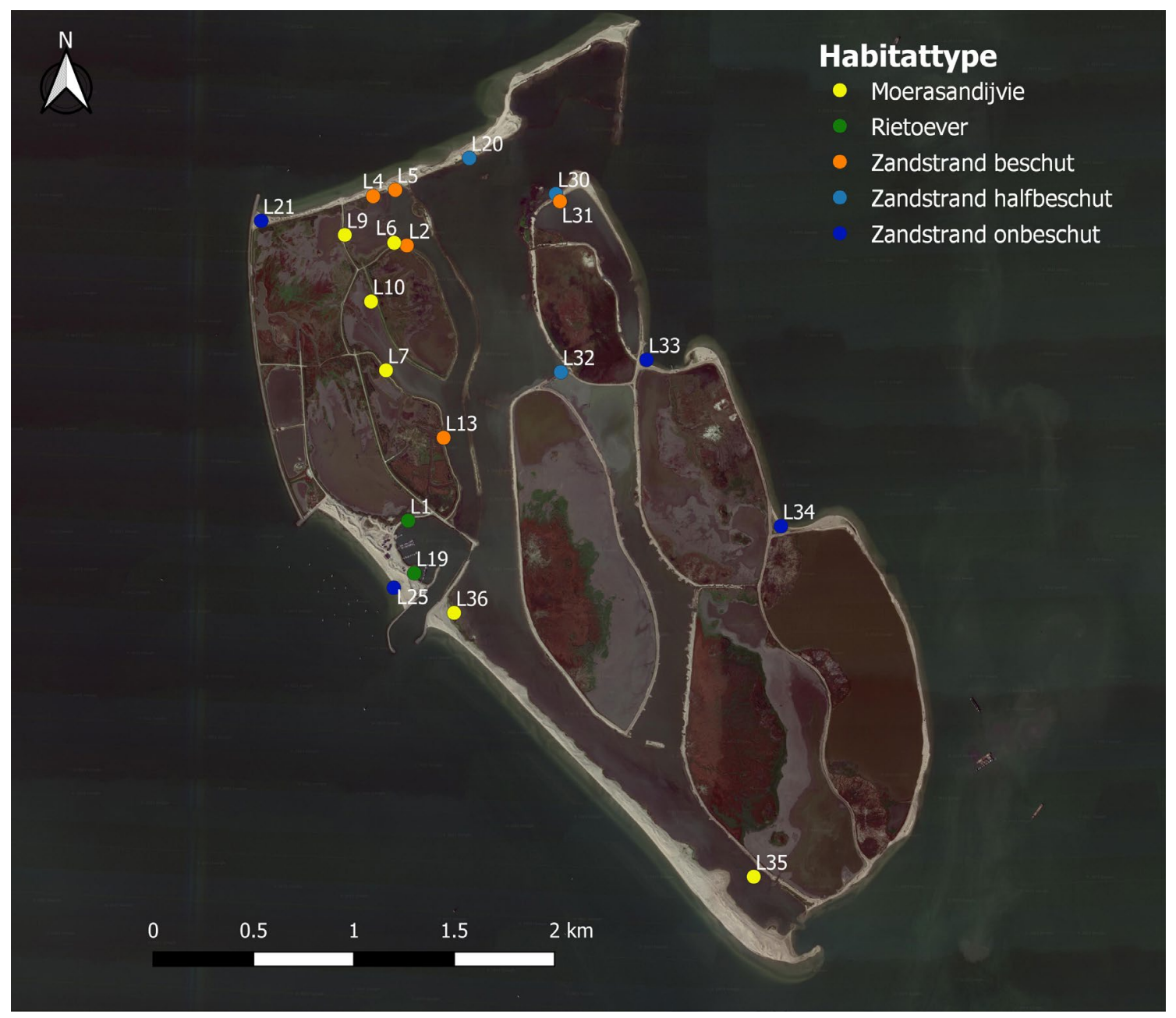

Figuur 1. Bemonsteringslocaties in de jaren 2019, 2020 en 2021. In 2019 zijn alleen de locatie L1, L6, L7, L10, L19, L21, L25 en L36 op het noordwestelijke (hoofd/eerste) eiland bemonsterd. In 2020 zijn alle locaties bemonsterd, en in 2021 zijn enkel de locaties L1, L4, L6, L13, L19, L20, L30 en L36 bemonsterd.

\subsection{Vis in fonteinkruidvelden westelijk Markermeer}

Rond Marker Wadden ontwikkelen zich gestaag waterplantvelden van voornamelijk fonteinkruiden. Ook op het IJsselmeer en Markermeer raken aanzienlijke oppervlaktes begroeid met ondergedoken waterplanten. Deze velden kunnen door vis op diverse manieren gebruikt worden, bijvoorbeeld voor het vinden van specifiek voedsel dat geassocieerd is met de waterplanten of als schuilplaats voor predatoren. Onderzoek naar aanwezigheid van vis in deze vegetatievelden op verschillende tijdstippen in het groeiseizoen en/of in een etmaal kan inzicht verschaffen in de functie van deze vegetatievelden voor vis. Echter, het bemonsteren van vis in dichte vegetatievelden is een lastige opgave. Naast vis wordt al snel een (te) grote hoeveelheid vegetatie mee gevangen waardoor de vangstefficiëntie van het gebruikte vistuig kan verminderden. 
Begin juli 2018 werd in drie dagen tijd in de Hoornse Hop (tussen Hoorn en Edam) een pilot bemonstering uitgevoerd in samenwerking met ATKB. Hierbij werd met drie verschillende vangtuigen getracht inzicht te verkrijgen in de doelmatigheid van deze vangtuigen voor onderzoek naar het gebruik van dit habitat door vis.

Er is bemonsterd op $3 \mathrm{t} / \mathrm{m} 5$ juli 2018. Op de eerste dag werd er met een stortkuil gevist ( 5 trekken), op de tweede dag met elektropuls draden (5 trajecten van ca. 300-500 m), en op de derde dag met een zegen ( 4 trekken).

\section{$\underline{\text { Stortkuil }}$}

De stortkuil is een palingkuil zoals die in de jaren '50 en '60 van de vorige eeuw op het IJsselmeer gebruikt werd. De naam stortkuil verwijst naar het gebruik van dit type kuil langs de steenstort van de aan te leggen dijken van de Flevopolders. Om beschadiging te voorkomen werd dit type kuil gemaakt van dik garen. De kuil heeft een bovenpees van 14 meter en wordt in span met twee kleine $(6,5-8$ meter) boten voortgetrokken met een snelheid van 4,5 tot $5 \mathrm{~km} / \mathrm{uur}$. De vissende breedte bedraagt 10 meter bij een hoogte van 1,5 meter. De maaswijdte in de bek van de kuil bedraagt $60 \mathrm{~mm}$ hele maas, afnemend tot $14 \mathrm{~mm}$ in de zak. De standaard treklengte bedraagt 1000 meter, maar dit werd in de vegetatievelden niet altijd gehaald. Wanneer de snelheid onder de $4 \mathrm{~km} / \mathrm{uur}$ daalde werd de trek afgebroken omdat de vangstefficiëntie bij een lagere snelheid en vervuiling van het net sterk afneemt.

\section{Elektropuls draden}

De elektropuls draden zijn bevestigd aan een boom van 2 meter die haaks op de zijkant van de boot gemonteerd is. De draden (10 stuks) die verticaal in het water hangen zijn 1,5 meter lang. Op de draden wordt een anodische gelijkspanning van ongeveer 300 volt gezet. De spanning wordt 160 keer per seconde voor ongeveer $50 \%$ van de tijd onderbroken. Door langzaam (ongeveer 1,5 km/uur) te varen wordt een strook van 2 meter breed bevist.

\section{Zegen}

Er is gevist met een zegen van 225 meter lang en gestrekt 8 meter hoog (vissend maximaal 6,5 meter hoog). De maaswijdte bedraagt $40 \mathrm{~mm}$ hele maas in de vleugels, afnemend tot $14 \mathrm{~mm}$ hele maas in de zak. De zegen werd in cirkelvorm uitgevaren en hydraulisch ingehaald. Het beviste oppervlak werd met een GPS met een oppervlaktefunctie bepaald.

\subsection{Zandwinputten rond Marker Wadden}

Op 19 en 20 augustus 2019 werd een eenmalige bemonstering uitgevoerd van 3 zandwinputten en de slibgeul rond Marken Wadden. Met behulp van een echolood (SIMRAD echo sounding splitbeam transducer, $200 \mathrm{kHz}$ ) werden transecten gevaren over de zandwinputten, bodemprofielen (diepteprofielen) gescand en visdichtheden bepaald op basis van target strengths. Tevens werden met een 5-m A-toomkuil (netoppervlak $5 \times 5 \mathrm{~m}$ ) op verschillende dieptes trekken gedaan in de 3 zandwinputten ( 3 trekken per put), maar niet over de taluds om te voorkomen dat het net vast zou komen te zitten in de wanden van de zandwinputten. De echoloodwaarnemingen gaven aan dat de meeste vis zich vrij in de waterkolom bevond, waardoor de bemonsteringen met de A-toomkuil waarschijnlijk een goed beeld gaven van de samenstelling van de visstand in de zandwinputten. 


\section{Resultaten}

\subsection{Habitats en habitatgebruik jonge vis Marker Wadden}

In de onderzoeksperiode 2019-2021 zijn verschillende habitattypen bemonsterd. In 2019 was nog grotendeels onduidelijk welke habitattypen zich zouden ontwikkelen en werd een grote variatie aan habitats bemonsterd. Vanaf 2020 werden relevante habitattypen meer systematisch bemonsterd, met name in de luwte van de eilanden (moerasandijvie, riet, beschutte en halfbeschutte zandoever).

\subsubsection{Dood hout}

In 2019 zijn de dode essen die op een ondiepte (waterdiepte ca. $1 \mathrm{~m}$ ) liggen een aantal keren bemonsterd met een larvennet. De bodem bestaat uit grof zand waarop zich een mobiele sliblaag heeft afgezet. De half ondergedompelde essen zijn grotendeels bedekt met niet nader onderzocht aangroeisel (Figuur 2). Tussen de takken was het moeilijk bemonsteren. Met een GoPro-camera zijn takken afgezocht op eventuele eisnoeren van baars, maar deze werden niet waargenomen. Er werden ook geen schooltjes vislarven of jonge vis waargenomen en er werd slechts een enkele marmergrondel gevangen met het larvennet. In 2020 en 2021 is dit habitat niet verder onderzocht.
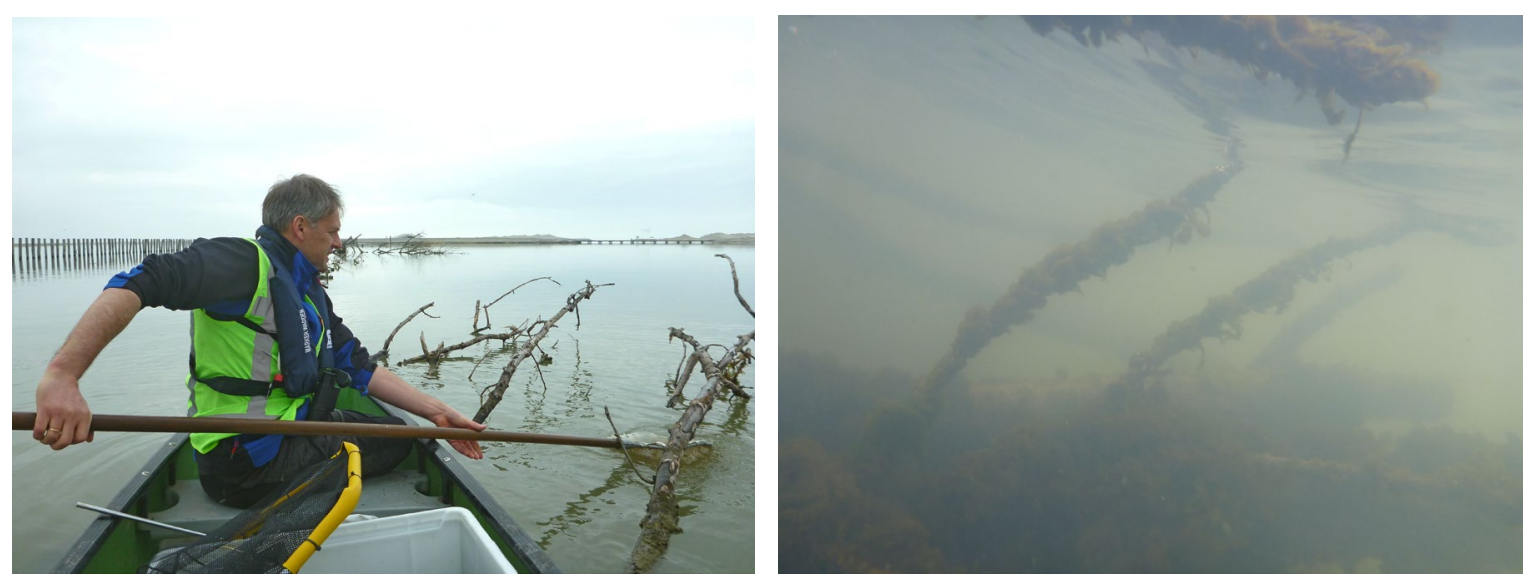

Figuur 2. Bemonstering van habitat 'dood hout' ten noorden van de haven, links 19 april 2019, rechts 17 mei 2019. Foto's: Jelger Elings, Joep de Leeuw.

\subsubsection{Steenoever}

Steenoevers zijn aangelegd als havenhoofden bij het hoofdeiland, een strekdam aan de noordwestzijde en incidentele versterkingen zoals bij de wash-overs in de zandige westrand van het hoofdeiland, waar bij harde westenwind water de aangrenzende bassins of compartimenten in kan spoelen. Met het larvennet en RAVON-net zijn in 2019 pogingen gedaan om vislarven te bemonsteren langs stenen oevers bij de haven en het noordstrand. Hoewel regelmatig schooltjes kleine larven werden waargenomen bleek het buitengewoon lastig om tussen en net buiten de stenen larven te vangen. Vermoedelijk ging het in veel gevallen om baars (voor zover zichtbaar op het oog). In de monitoring van Sportvisserij Nederland (Van Emmerik 2020a, 2020b, 2021) wordt dit habitat met electrovisserij vanuit een boot bemonsterd in mei en september. In mei gaat het om oudere vis en in september ook om jonge vis. Daarbij is niet duidelijk in hoeverre deze steenoevers als paai- en opgroeigebied zijn benut of dat vis van elders kwam. 


\subsubsection{Moerasandijvie}

Moerasandijvie is een pionierssoort die domineert in de ondiepe land-water overgangszone. Grote velden van moerasandijviepollen vormden zich in de luwte van de eilanden. Met name op slikkige ondergrond was de bodem onstabiel en lastig om wadend te bemonsteren. Waar mogelijk werden locaties met larvennet, RAVON-net en broedzegen (figuur 3) bemonsterd. Met het larvennet werden ook de ondiepe vlaktes (ca. 1 decimeter diep) die als open stukken in de moerasandijvievelden voorkwamen bemonsterd. Daarnaast werden de oeverzones en geulen die deel uit maken van de moerasandijvievelden bemonsterd, evenals (met de broedzegen) de ondieptes tot ca. $1 \mathrm{~m}$ diep in aansluiting op de moerasandijvievelden. In het voorjaar werden paaiende vissen (onder andere driedoornige stekelbaars, karper en brasem) waargenomen en net na de paai soms dode volwassen vis, zoals blankvoorn en snoek, die zich mogelijk te ver op de ondieptes had gewaagd en niet meer terug kon naar dieper water. Kleine larven werden vooral aangetroffen op de ondieptes (centimeters tot decimeters diep) die in het voorjaar snel opwarmen. In de loop van de zomer werd jonge vis meer aangetroffen langs de oevers van het meer open water, in de geulen en in de (vanaf 2020) aangrenzende waterplantvelden.

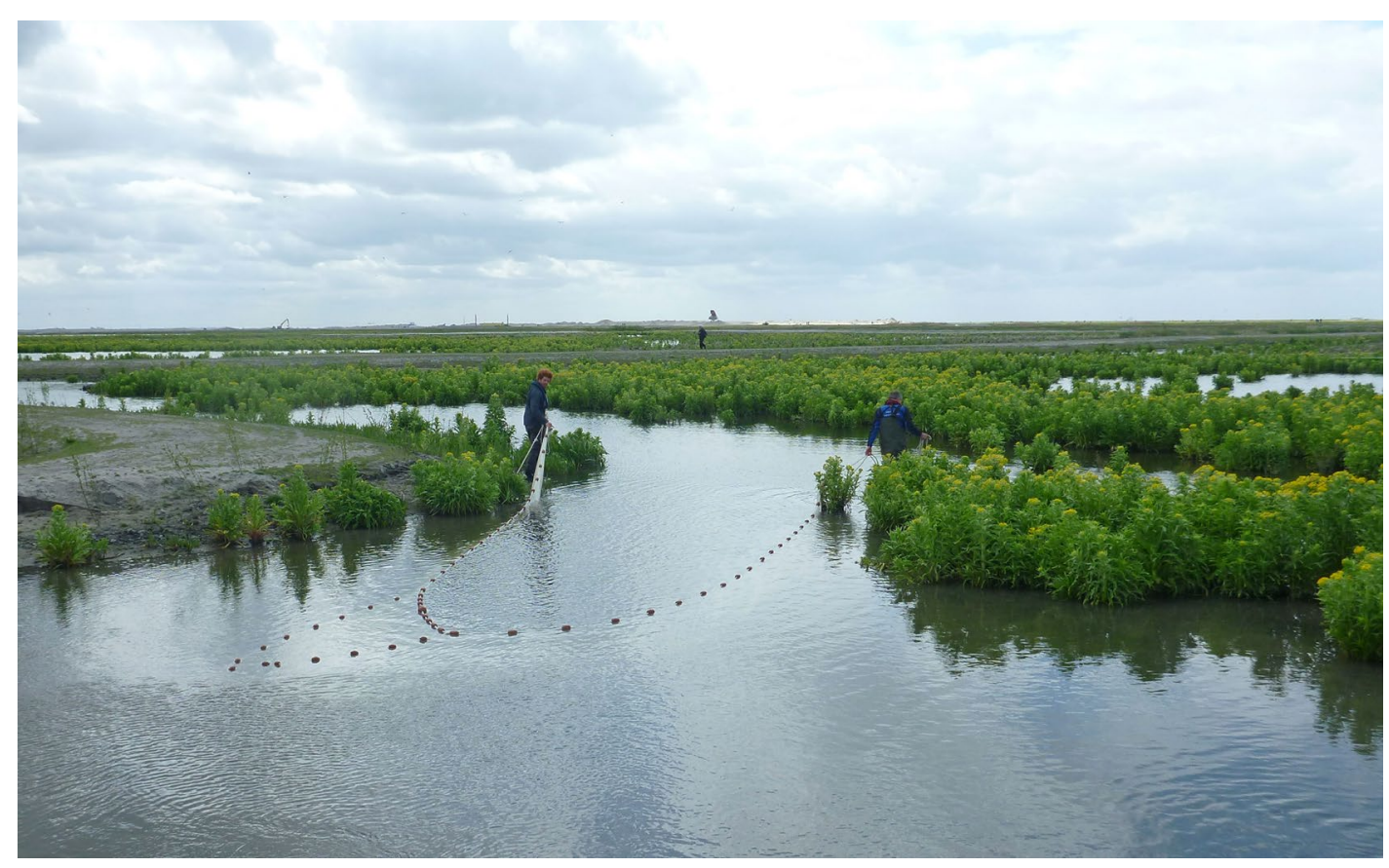

Figuur 3. Bemonstering met broedzegen van een ondiepe geul in een moerasandijvieveld bij kijkscherm "Aalscholver" (L6). Foto: Leo Nagelkerke.

\subsubsection{Rietoever}

Rietoevers die in open verbinding staan met het open water en vanaf het begin bereikbaar waren voor vis werden vooral gevonden in de haven. Door de bedrijvigheid aldaar (en stukken oever met afrastering) was er vrijwel geen ganzenvraat en konden zich al vroeg rietstroken ontwikkelen in de oeverzone. In 2019, 2020 en 2021 zijn deze habitats systematisch bemonsterd met larvennet, RAVON-net en broedzegen. Door de zandige ondergrond waren de rietstroken wadend goed te bemonsteren. Met de broedzegen werden ook fonteinkruidvelden (tot ca. $2 \mathrm{~m}$ diep) bemonsterd die grensden aan de rietoevers. Kleine larven werden vooral tussen het riet en langs de rietstroken aangetroffen, terwijl in de loop van de zomer kleine vis ook en vaker tussen de aangrenzende fonteinkruiden werd aangetroffen, onder andere tussen (en onder) de steigers. De taluds zijn relatief steil en de haven heeft grotendeels de oorspronkelijke waterdiepte van ruim $4 \mathrm{~m}$. Voor veel soorten volwassen vis is de haven jaarrond een belangrijk habitat. 


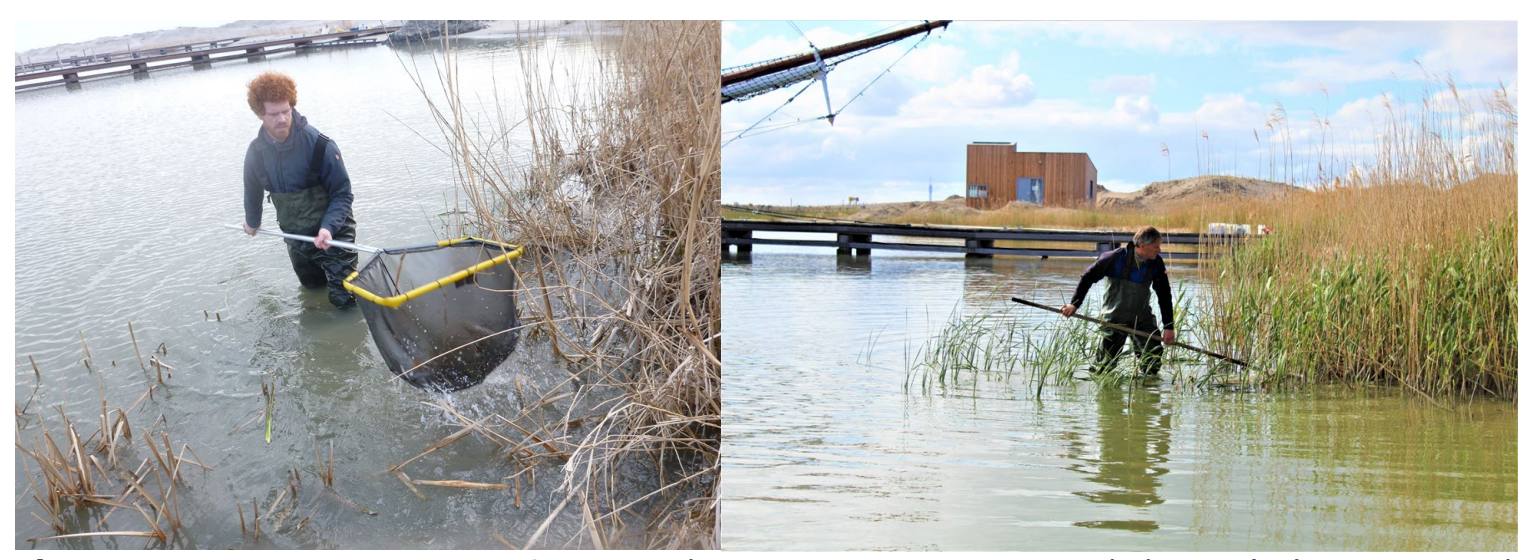

Figuur 4. Bemonstering met RAVON-net en larvennet van rietoevers in de haven (L1). Foto: Joep de Leeuw, Joey Volwater.

\subsubsection{Beschutte zandoever}

Beschutte zandoevers bestaan uit hoofdzakelijk kale flauwe taluds in de beschutting van de eilanden waar de effecten van wind relatief beperkt zijn. In de diepere delen van de oever ontwikkelt zich onderwatervegetatie, met name fonteinkruid, aarvederkruid en Zanichellia die zich uitbreidde gedurende de onderzoeksperiode. Beschutte zandoevers liggen in de buurt van moerasandijvievelden, waar de bodem bestaat uit zeer voedselrijk slib. Een deel van de plantaardige productie (waaronder plantenresten en zaden) van deze velden belandt op de oeverzones van zandstranden als een soort vloedmerk. De nabijheid van moerasandijvievelden met voedselrijk slib draagt bij aan de nutriëntenstroom en aan een daardoor iets hogere productie van benthos als voedsel voor jonge vis (C.H.A. van Leeuwen et al., in prep).

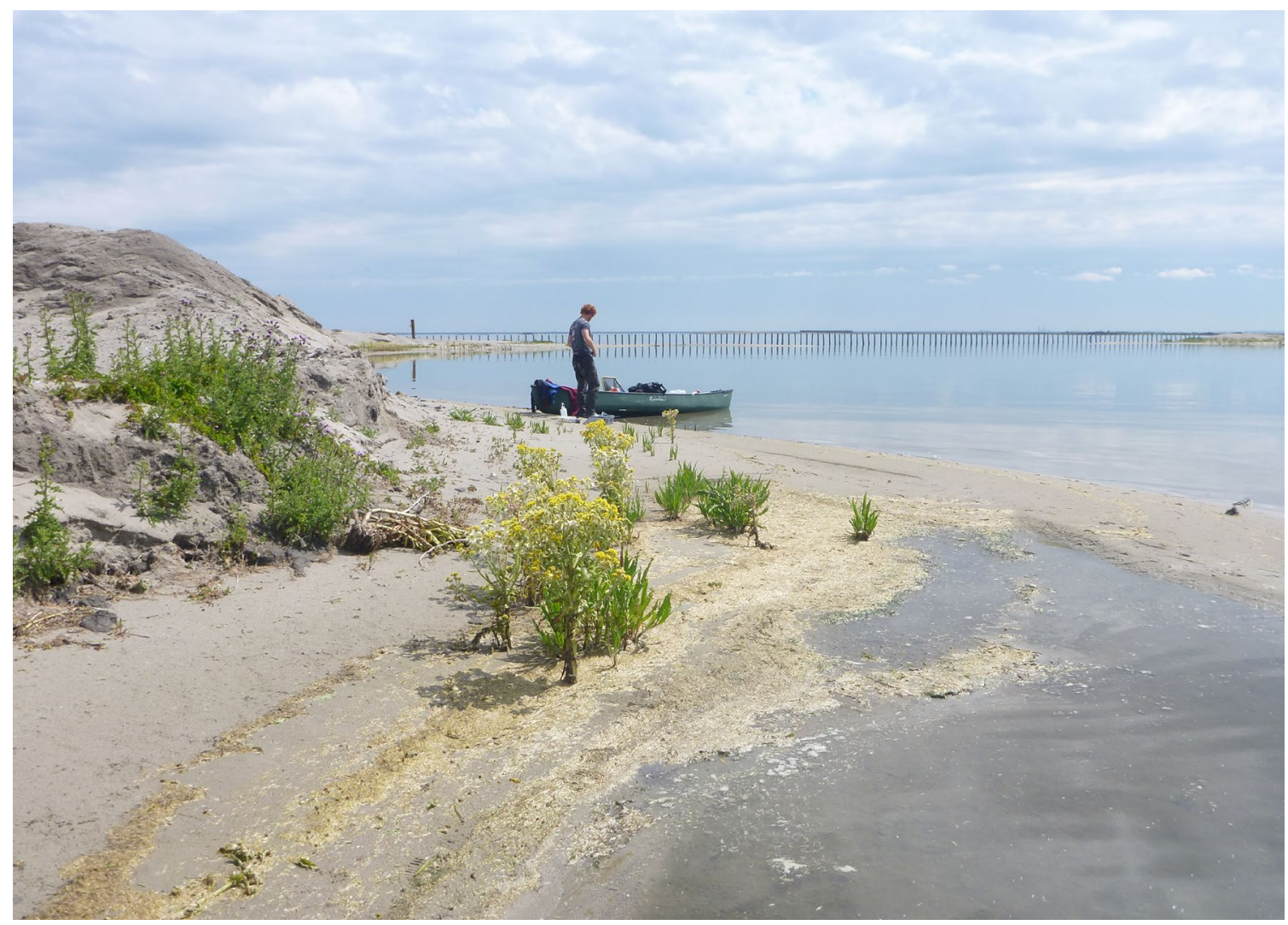

Figuur 5. Beschutte zandoever in het noordelijk deel van het hoofdeiland tegenover het kijkscherm (L4/L5). Foto: Joep de Leeuw.

\subsubsection{Halfbeschutte zandoever}

Halfbeschutte zandoevers liggen tussen de eilanden, maar in de meer open delen en dus wat meer geëxponeerd voor wind dan beschutte oevers. Op allerlei ondieptes tussen de eilanden en in de luwte 
van de eilanden komt vegetatieontwikkeling op gang. Doordat deze habitats vaak dichter in de buurt liggen van het open water van het Markermeer worden deze habitats in de loop van de zomer ook bezocht door jonge vis die mogelijk van elders uit het meer komt.

\subsubsection{Onbeschutte zandoever (buitenzijde eilanden)}

In 2019 en 2020 zijn met het larvennet, RAVON-net en (alleen in 2020) met de broedzegen enkele geëxponeerde zandoevers aan de buitenzijde van Marker Wadden bemonsterd (L25 westoever bij de nederzetting en L21 noordstrand en in 2020 ook L33 en L34 aan de oostzijde van de nieuwe eilanden). Bij westelijke wind komt veel golfslag en erosie voor bij L25 (en bij meer noordwestelijke wind ook bij L21, Figuur 6). De oeverzones bestaan hier uit een brede strook ondiep water van ca. $1 \mathrm{~m}$ diepte. Rond Marker Wadden komt nog nauwelijks vegetatieontwikkeling voor. De zandoevers stonden gedurende de onderzoeksperiode dus niet in verbinding met fonteinkruidvelden op dieper water rond de eilanden. De onbeschutte oevers behoren tot de karigste aquatische habitats van Marker Wadden (C. van Leeuwen, in prep.). Er werd zeer weinig vis waargenomen, voornamelijk Pontische stroomgrondel (in 2019) en kleine aantallen baars en blankvoorn (in 2020). Dit habitat wordt jaarlijks met een (broed)zegen in mei en september bemonsterd door Sportvisserij Nederland (Van Emmerik 2020a, 2020b, 2021), waarbij naast grondels ook andere soorten die algemeen in open water voorkomen zoals als spiering, alver, baars en blankvoorn aangetroffen worden.

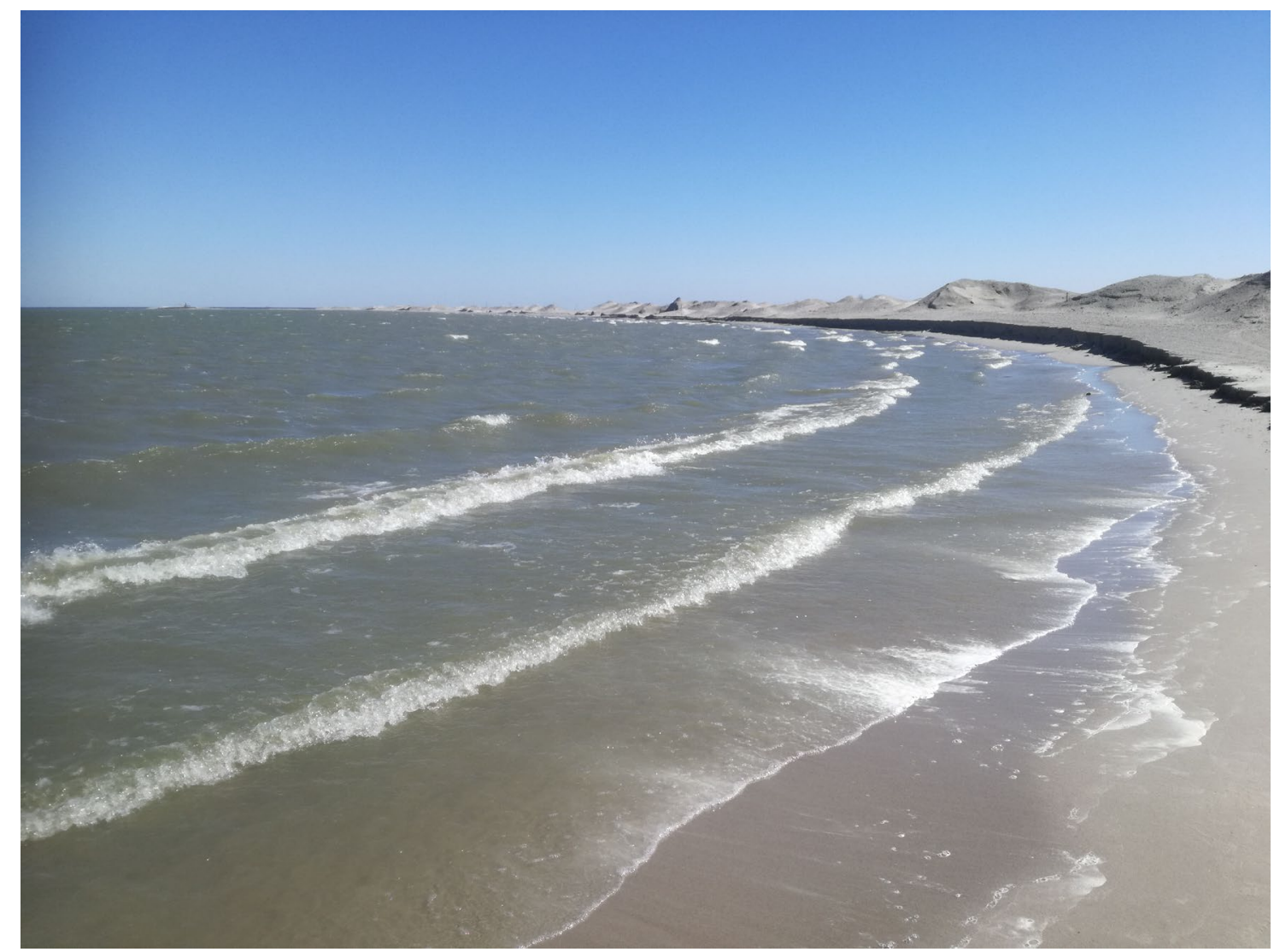

Figuur 6. Locatie L21, 10 april 2019. Zeer geëxponeerd zandstrand met brede ondiepe strandzone. Foto: Joep de Leeuw.

\subsection{Ontwikkelingen in voorkomen vislarven}

In dit hoofdstuk worden de seizoensontwikkelingen in respectievelijk 2019, 2020 en 2021 beschreven in soortsamenstelling en groei van vislarven in 5 habitats, te weten (1) moerasandijvievelden, (2) rietoever, (3) beschutte zandoever, en (4) halfbeschutte zandoever, in de relatief luwe delen tussen de eilanden, en (5) onbeschutte zandoevers aan de buitenzijde van de eilanden. 


\subsubsection{9}

In 2019 (en 2020) waren de compartimenten op de eilanden nog afgesloten van de omliggende wateren en kwam er vrijwel geen vis voor in de compartimenten. Door het vrijwel ontbreken van begrazingsdruk door vis ontstond binnen de compartimenten een tijdelijke opleving van grote daphnia's en ander plankton, grote hoeveelheden aasgarnalen, vlokreeften, waterwantsen en andere pelagische macrofauna. Maar ook in de luwte aan de oostzijde van het hoofdeiland in de geulensystemen en land-waterovergangen die in open verbinding stonden met het Markermeer werden, ondanks dat er veel activiteit van vissen was, grote hoeveelheden daphnia's, aasgarnalen en waterwantsen aangetroffen. Er werden volwassen vissen waargenomen die paaiden op de ondieptes en met name langs vegetatierijke oeverzones en ondieptes werden grote hoeveelheden vislarven aangetroffen.

In 2019 zijn enkel de habitattypen rietoever en moerasandijvie structureel door het seizoen heen bemonsterd. Tijdens de bemonsteringen werden in totaal 14 verschillende soorten vis aangetroffen. Winde en blankvoorn waren verantwoordelijk voor het merendeel van de vangsten aan vislarven (Figuur 7 en 8). Ook werden pos, baars, driedoornige stekelbaars, zwartbekgrondels en Pontische stroomgrondels in het merendeel van de vistrekken waargenomen. Windes werden als eerste soort in grote aantallen aangetroffen in de rietoevers rond de haven. De lengte van de gevangen windes varieerde tussen de 10 en $17 \mathrm{~mm}$ (Bijlage B2.6). In juni werden zowel in de rietoevers als tussen de moerasandijvievelden grote aantallen larven van blankvoorn, winde en driedoornige stekelbaars gevangen. Daarnaast zijn in juni tussen de moerasandijvie nog een aantal karpers (overige in figuur 2) gevangen waarbij de lengte varieerde tussen de 8 en $23 \mathrm{~mm}$. Baars werd in 2019 pas in juli voor het eerst in grote aantallen gevangen waarbij de lengte varieerde rond de $40 \mathrm{~mm}$. Dat baars pas laat in het seizoen voor het eerst waargenomen werd met een lengte rond de $40 \mathrm{~mm}$ is waarschijnlijk het gevolg van het gebruikte vistuig (Bijlage 1), omdat pas in juli is gestart om de 15-m broedzegen te gebruiken voor alle locaties. Het is mogelijk dat baars elders en in dieper water paaide bij gebrek aan geschikt hard substraat (Čech et al. 2012) in de net aangelegde oeverstroken met instabiele bodems, en dat jonge baars pas later in de loop van de zomer richting rietoevers en moerasandijvievelden trok. In september zijn, met name in de rietoevers, onder andere alver, spiering en brasem aangetroffen. Het betrof over het algemeen wat grotere, meerjarige individuen.

\section{9}
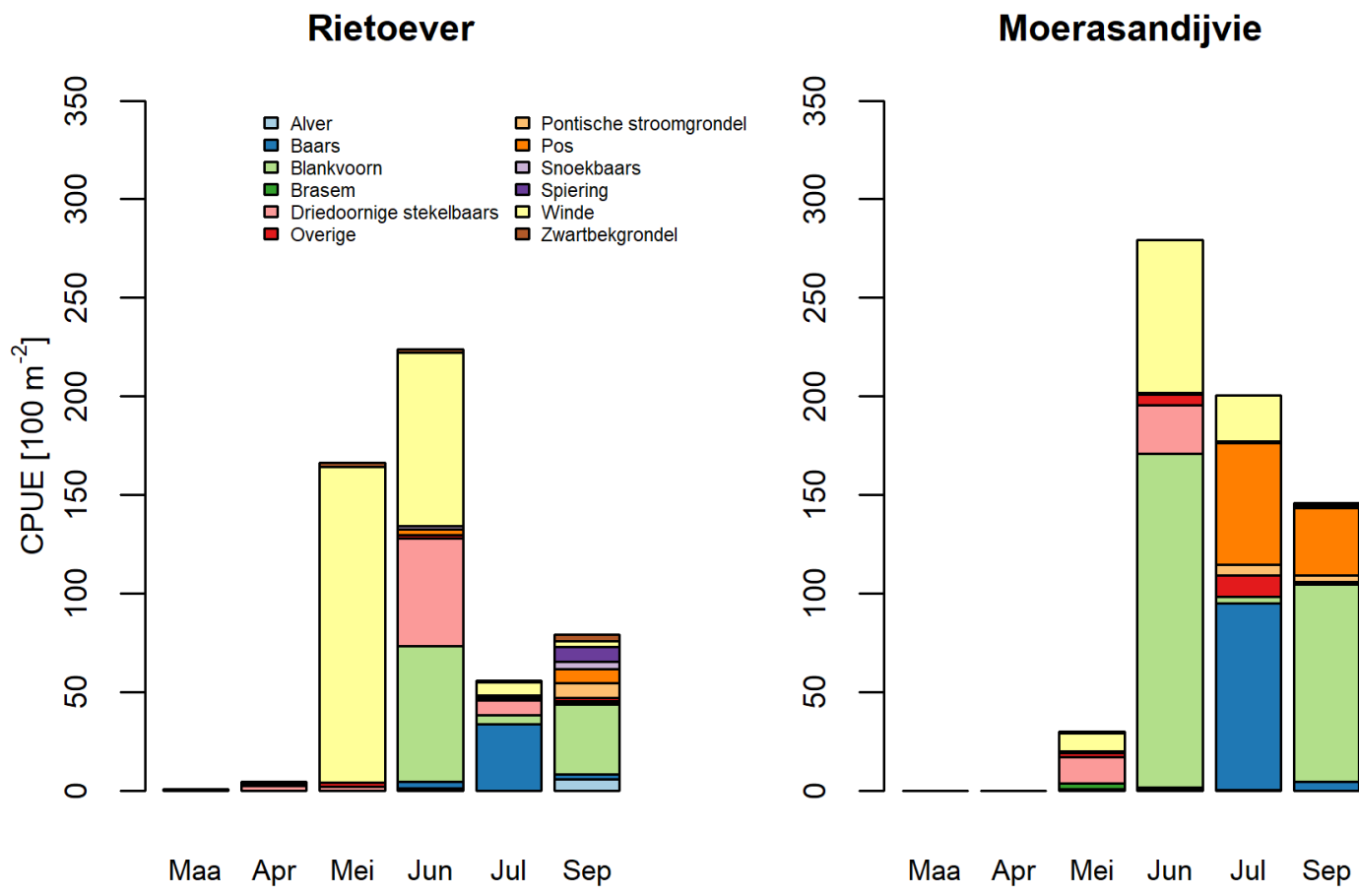

Figuur 7. Vangst in aantallen vislarven per inspanning (cpue, $100 \mathrm{~m}^{-2}$ bevist oppervlakte) gemiddeld per maand voor habitattypen rietoever en moerasandijvieveld in 2019. 


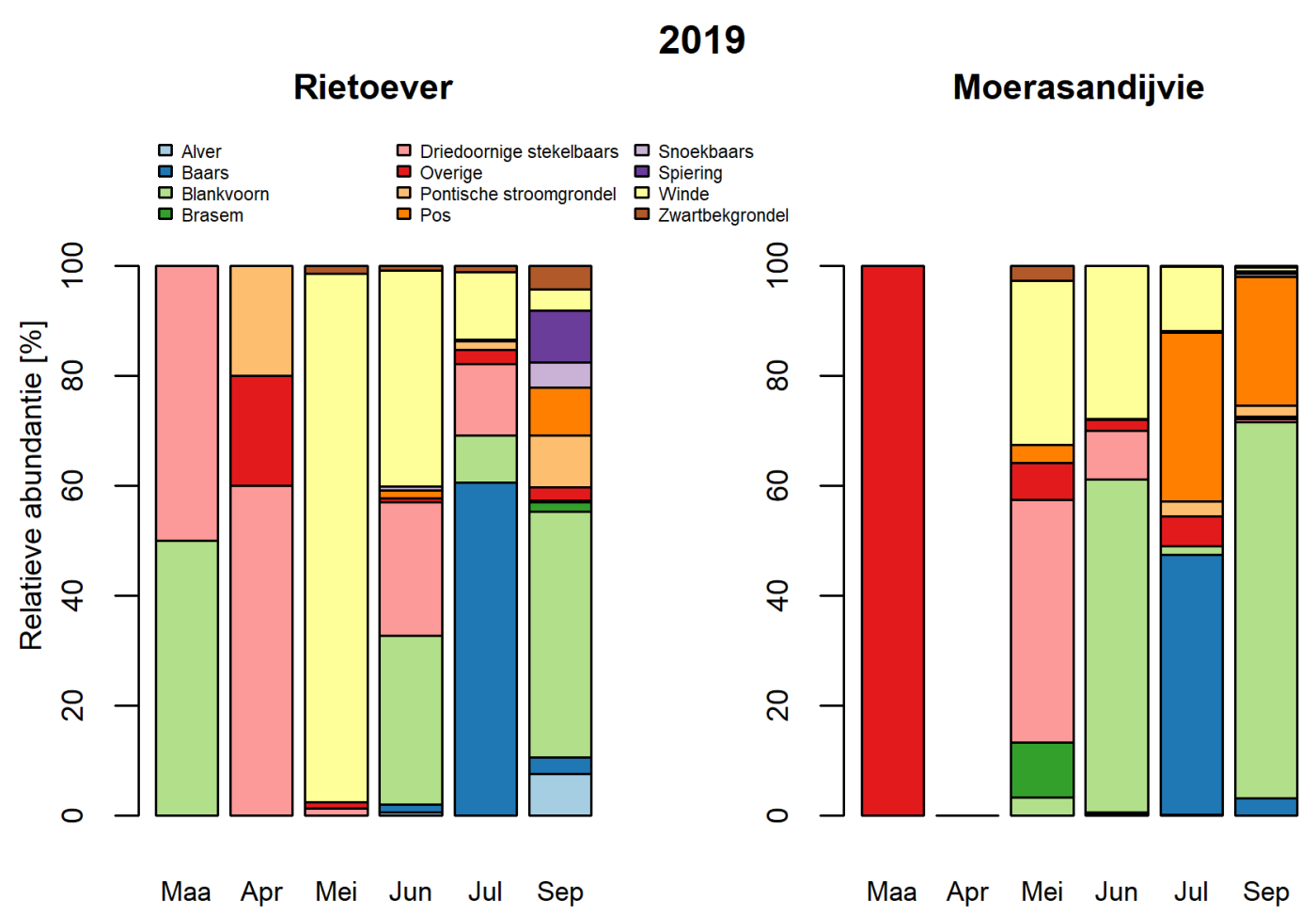

Figuur 8. Soortsamenstelling van de vangst (percentage van het totaal aantal gevangen vislarven) per maand en per habitat in 2019.

\subsubsection{0}

In 2020 werden vijf verschillende habitattypen structureel door het seizoen heen bemonsterd: rietoever, moerasandijvie, zandoever beschut, zandoever halfbeschut en zandoever onbeschut. Tijdens de bemonsteringen in 2020 werden in totaal 15 verschillende vissoorten aangetroffen. Baars, blankvoorn en pos domineerden de vangsten (Figuur 9 en 10). Daarnaast werden snoekbaars en grondels ook in het merendeel van de vistrekken gevonden. Voor alle habitattypen werd een afname in dichtheid van juveniele vissen door het seizoen heen waargenomen (Figuur 9). De afname in dichtheid door het seizoen heen is deels het gevolg van natuurlijke mortaliteit maar kan ook deels veroorzaakt zijn door een verminderde vangstefficiëntie naar mate de vislarven/juveniele vis groter worden, ondanks het geleidelijk aan meer inzetten van grotere netten met wijdere mazen. In tegenstelling tot 2019 werd in 2020 blankvoorn als eerste soort in grote aantallen aangetroffen. Blankvoorn werd in alle vier de habitattypen gevangen, maar met name in de rietoevers werden de hoogste dichtheden aangetroffen. Er werd veel zeer kleine blankvoorn aangetroffen, vrijwel uitsluitend met een lengte van $<10 \mathrm{~mm}$ (Bijlage 2.2). Ook baars $<10 \mathrm{~mm}$ werd al gevangen in mei. De aantallen waren echter beperkt, waarschijnlijk omdat in mei alleen met een larven schepnet en het RAVON-net werd bemonsterd (klein oppervlak). In juni werd naast de schepnetten ook gebruik gemaakt van de 10-m broedzegen en werden grote hoeveelheden baars gevangen. De vangsten van de moerasandijvie-locaties werden gedomineerd door pos. Pos was dominant op slibrijke ondergrond. Ook op de beschutte zandoevers, waar veelal ook slib te vinden was werd door het seizoen heen veel pos gevangen. Snoekbaars werd in 2020 beduidend meer gevangen dan in 2019 (Figuur 10). In juni werd snoekbaars variërend in lengte van 24 tot $45 \mathrm{~mm}$ gevangen (bijlage b2.5). Grondels werden het meest aangetroffen op de drie zandoever habitattypen, met name op de onbeschutte zandoevers.

Op 16 juni 2020 werden ook op Trintelzand pionierhabitats met geulen en zandplaten bij moerasandijvievelden bemonsterd (bijlage 5). Hierbij werden 9 soorten aangetroffen, waaronder vooral baars en snoekbaars. Daarnaast werden winde en in kleine aantallen alver, blankvoorn, pos, driedoornige stekelbaars, Pontische stroomgrondel en zwartbekgrondel gevonden. Het grote aantal baarsjes komt overeen met de in juni relatief grote hoeveelheden baars bij moerasandijvievelden en zandplaten op Marker Wadden. Op Trintelzand werd winde aangetroffen in de geulen bij moerasandijvievelden, terwijl winde op Marker Wadden niet in dat jaar werd gevonden, maar wel in 2019. 

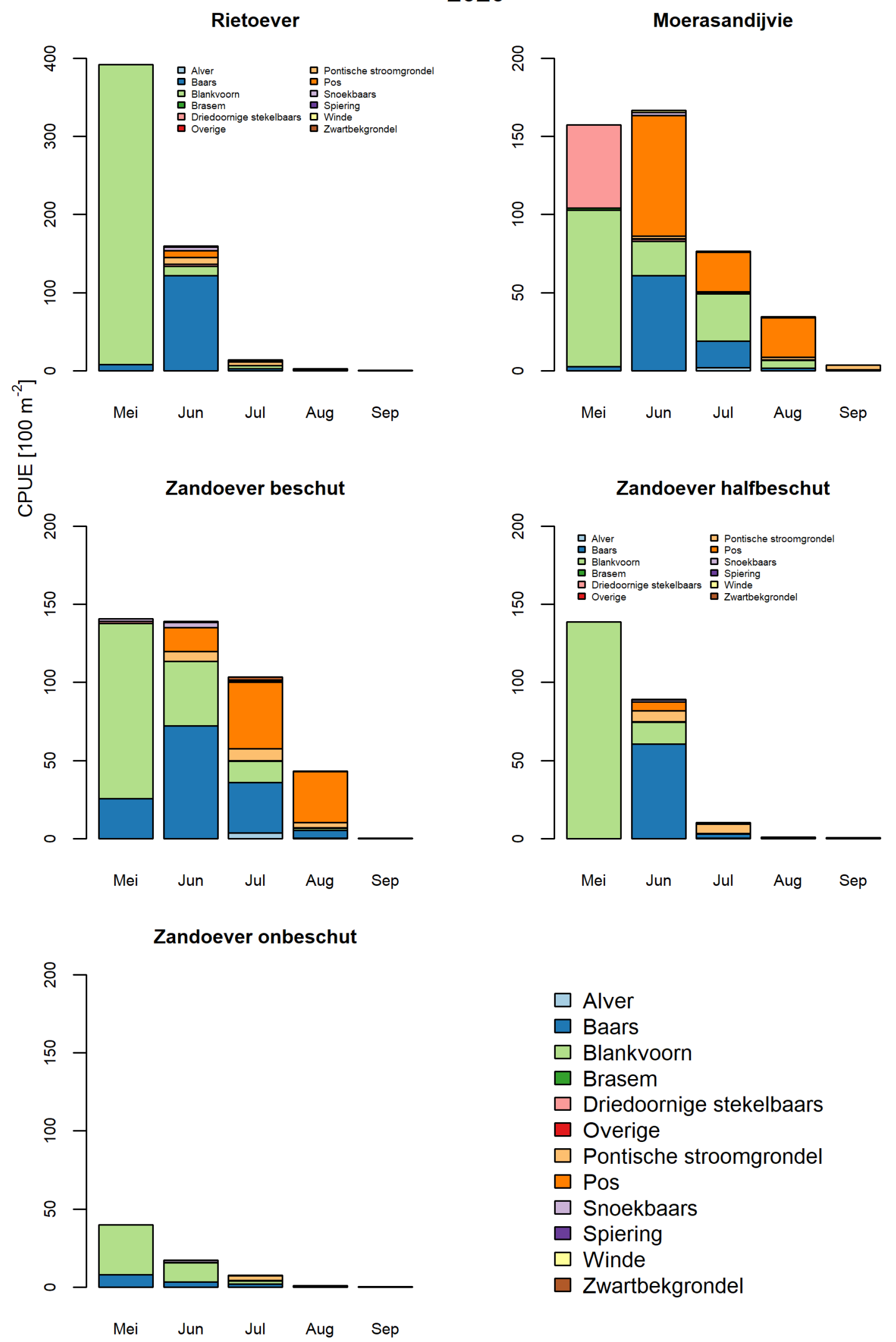

Figuur 9. Vangst in aantallen vislarven per inspanning (cpue, $100 \mathrm{~m}^{-2}$ bevist oppervlakte) gemiddeld per maand en habitattype in 2020. 
Rietoever
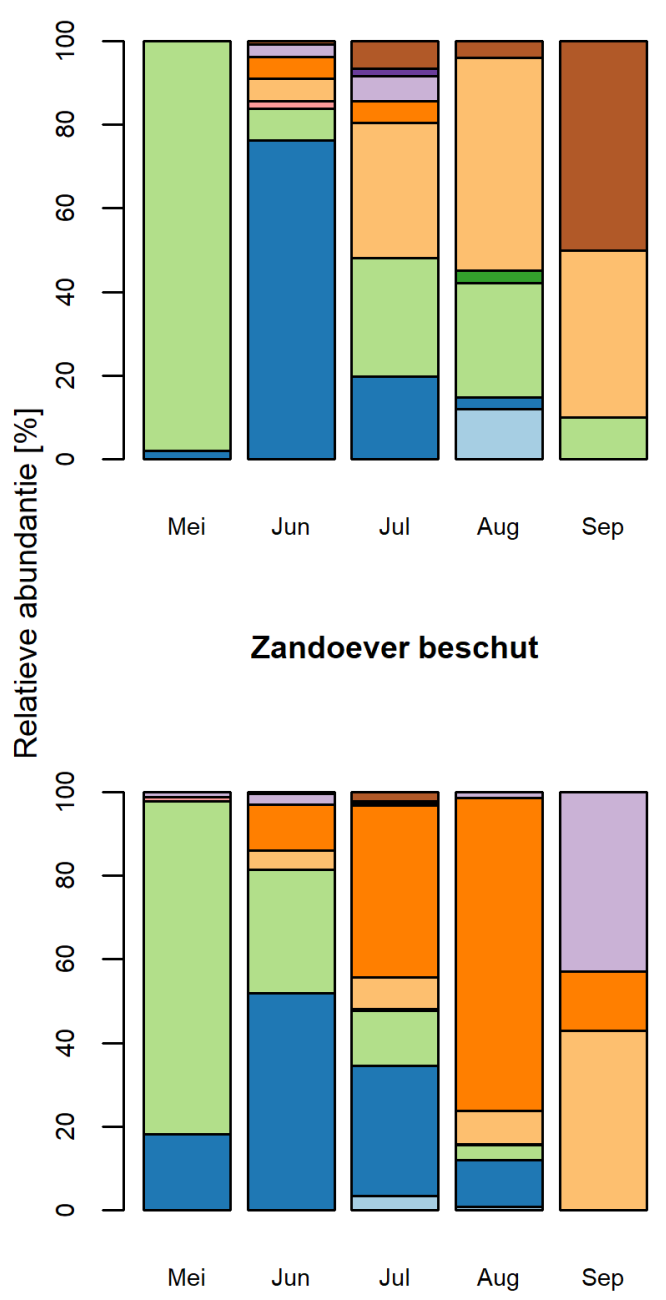

Zandoever onbeschut

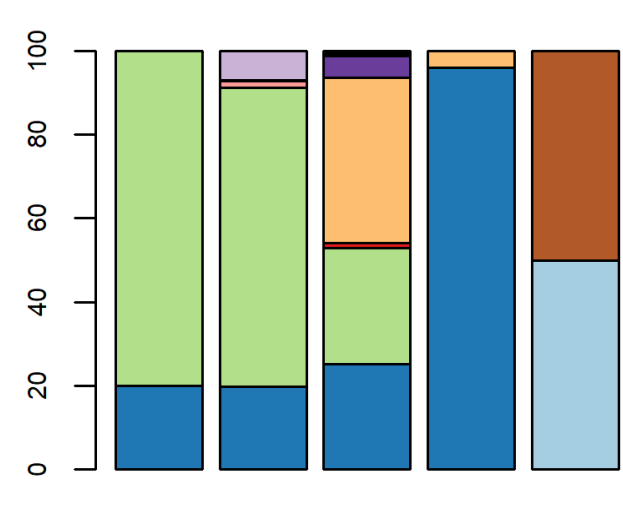

Moerasandijvie

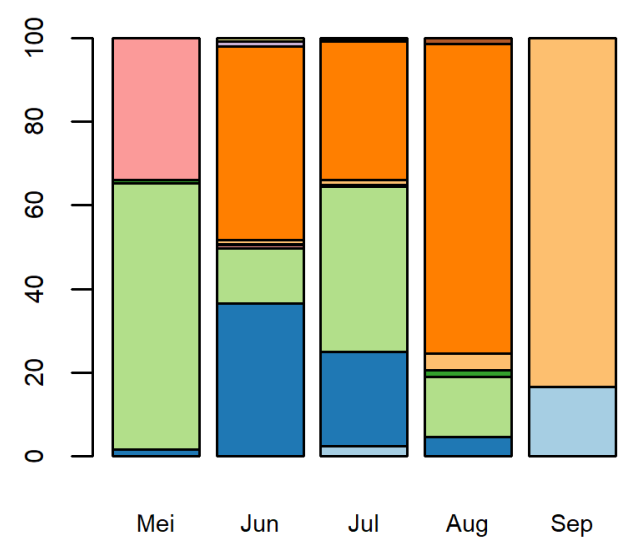

Zandoever halfbeschut

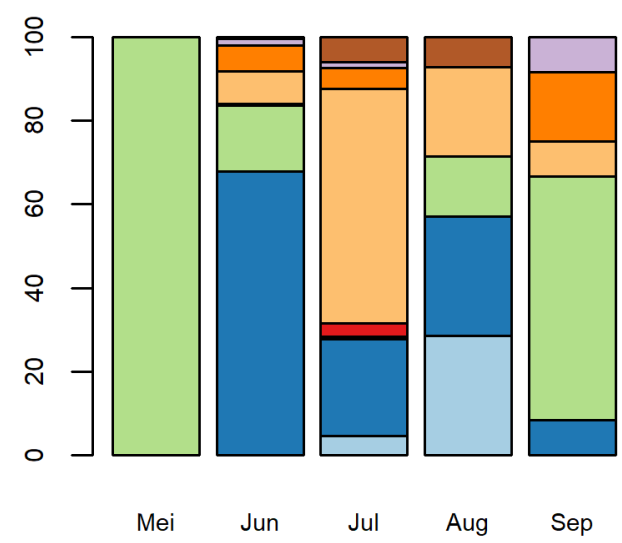

Figuur 10. Soortsamenstelling van de vangst (percentage van het totaal aantal gevangen vislarven) gemiddeld per maand en per habitat in 2020.

\section{2 .32021}

In 2021 was de bemonsteringsopzet iets beperkter dan in 2020, maar werden wel de vier habitattypen rietoever, moerasandijvie, zandoever beschut en zandoever onbeschut structureel door het seizoen heen bemonsterd. Net als in 2020 werd in mei gestart met de larvenbemonstering, maar doordat de 


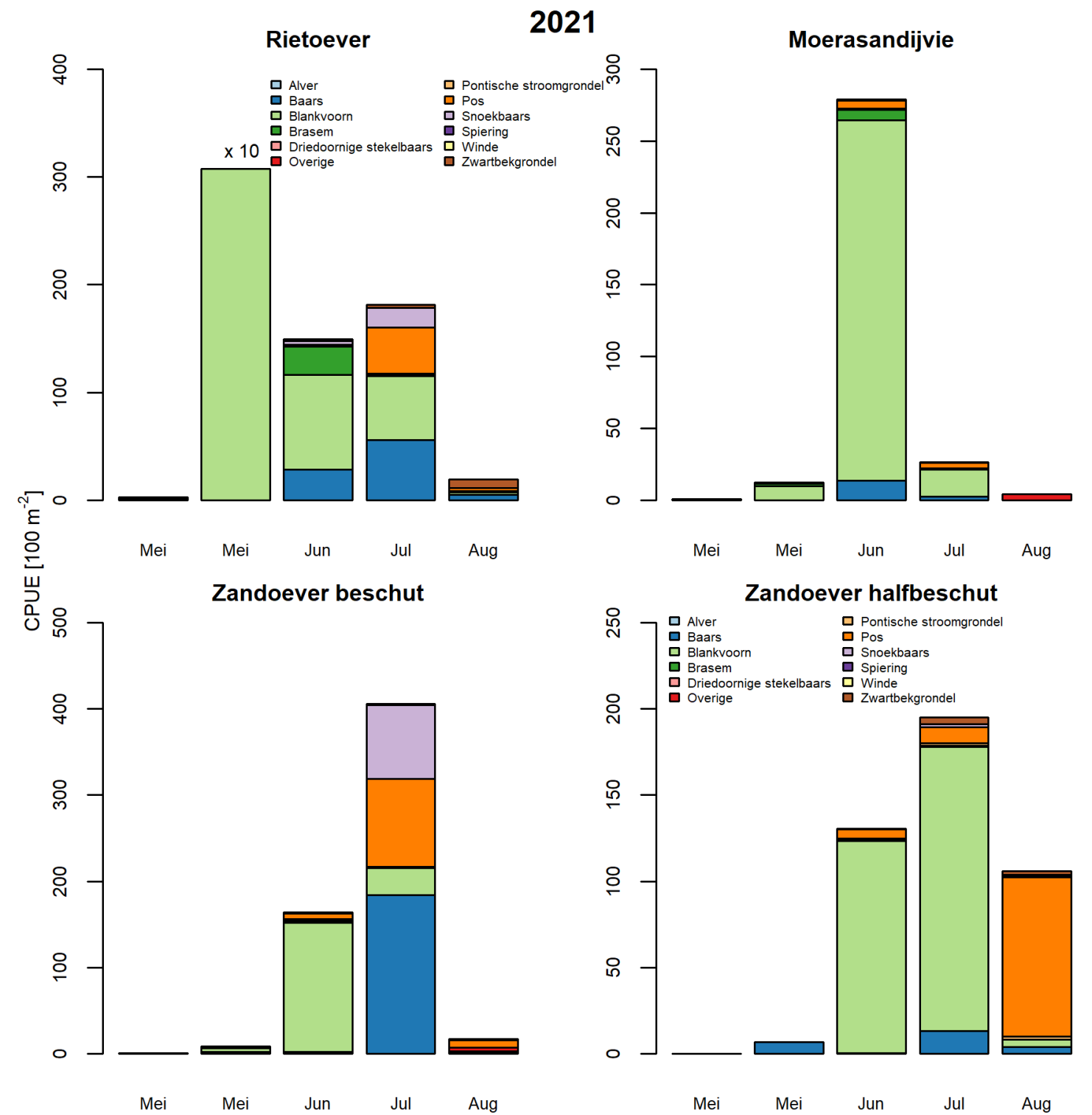

Figuur 11. Vangst in aantallen vislarven per inspanning (cpue, $100 \mathrm{~m}^{-2}$ bevist oppervlakte) gemiddeld per maand en habitattype in 2021.

temperatuur van het water in het voorjaar maar langzaam opliep, en daardoor de paai van vissen pas laat in het voorjaar plaatsvond, is een extra dag eind mei bemonsterd.

Tijdens de bemonsteringen in 2021 werden in totaal 14 verschillende vissoorten aangetroffen. Een soort die in de voorgaande bemonsteringen nog niet werd aangetroffen, de Kaukasische dwerggrondel, werd in 2021 meermaals gevangen. Blankvoorn, baars en pos waren verantwoordelijk voor veruit het grootste deel van de vangsten (Figuur 11 en 12). Daarnaast was ook snoekbaars verantwoordelijk voor een aanzienlijk deel van de vangsten, met name voor het habitattype beschutte zandoevers. Kleine brasem $(<15 \mathrm{~mm}$ ) werd gevangen in juni in alle vier de habitattypen, de meeste in rietoevers. Net als in de eerdere jaren werden grondels in het merendeel van de vistrekken waargenomen. Vanwege het achterblijven van de watertemperatuur in het voorjaar - begin april daalde de temperatuur tot onder de 7 graden - werd in de meeste habitattypen de hoogste dichtheid aan larven pas waargenomen in juni of juli.

Net als in 2020 werden in 2021 van blankvoorn als eerste soort grote aantallen larven aangetroffen, met in mei vooral zeer hoge dichtheden in de rietoevers. Blankvoorn was wijdverspreid over Marker Wadden en werd in mei in alle vier de habitattypen gevangen vanaf een lengte van $5 \mathrm{~mm}$. In mei en juni werd baars $<10 \mathrm{~mm}$ gevangen in alle habitattypen, echter waren de aantallen in vergelijking tot blankvoorn gering. In juli werden naast blankvoorn en baars ook snoekbaars en pos in behoorlijke aantallen gevangen. Snoekbaars werd meer gevangen dan in 2020 en in juli hadden de juveniele een lengte variërend tussen de 30 en $70 \mathrm{~mm}$. Pos werd in de hoogste dichtheden aangetroffen op de 
zandoevers, met name in augustus op de onbeschutte zandoevers. Naast bovengenoemde soorten werd ook juveniele karper ( $<70 \mathrm{~mm}$ ) aangetroffen, maar uitsluitend in de beschutte zandoevers waar veelal ook slib te vinden was. Kleine modderkruiper was ook al in de bemonsteringsjaren 2019 en 2020 aangetroffen op Marker Wadden, maar in 2021 werd voor het eerst een larve (lengte 14 mm) gevangen tussen de moerasandijvie.

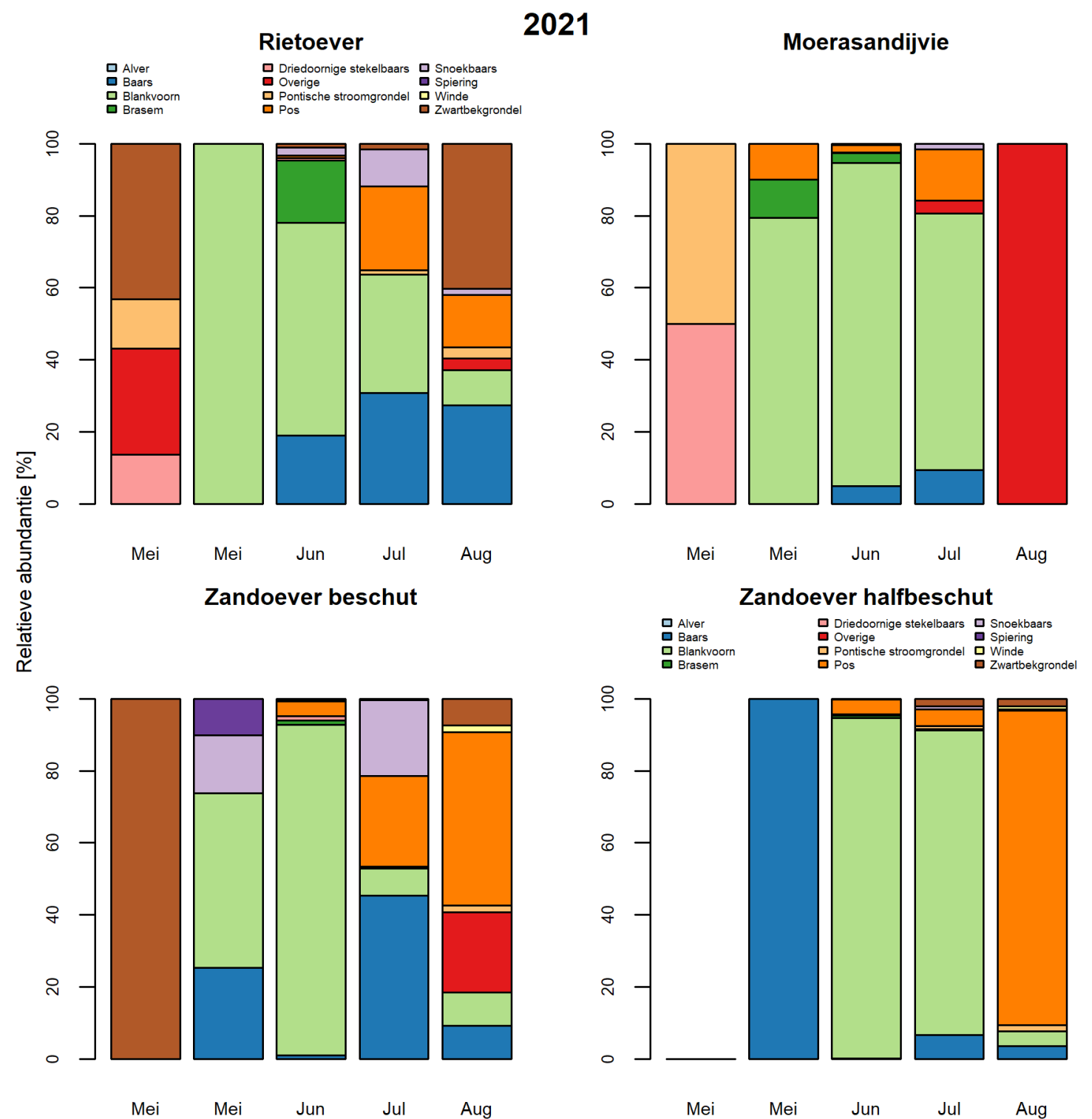

Figuur 12. Soortsamenstelling van de vangst (percentage van het totaal aantal gevangen vislarven) gemiddeld per maand en per habitat in 2020.

\subsection{Effecten van omgevingsvariabelen wind en temperatuur}

Windgegevens zijn verkregen via het Koninklijk Nederlands Meteorologisch Instituut (KNMI) van de meetpaal op de Houtribdijk (nummer 258). Gezien de ligging van Marker Wadden ten opzichte van dit meetstation, is aangenomen dat de gemeten windrichting en windsnelheid representatief zijn voor Marker Wadden.

In 2019 was gedurende vrijwel de hele maand maart de dominante windrichting vanuit het westen. Hierbij werd in het begin van maart constant een gemiddelde windkracht van 3 of meer Beaufort gemeten (Figuur 13, Bijlage 4). Deze dominante en straffe westenwinden moeten het waterniveau in het oostelijke deel van het Markermeer met enige decimeters opgestuwd hebben, en dus is de verwachting dat ook op Marker Wadden het waterniveau relatief hoog was in deze periode. In april draaide de wind en kwam deze vrijwel de gehele maand april vanuit het oosten met een gemiddelde windkracht van 2-3 Beaufort, waardoor de waterstand enkele decimeters lager was dan in de weken 
daarvoor. In 2020 was de windrichting veel wisselvalliger, er werd niet één dominante windrichting waargenomen over een langere periode. In 2021 was de windrichting in de maanden maart tot en met mei vrijwel uitsluitend uit het westen of noorden. Met name de tweede helft van april overheerste een noordelijke wind die zorgde voor een late ontwikkeling van de watertemperatuur.

Temperatuurgegevens werden verkregen van de Rijkswaterstaatmeetpaal op Marker Wadden. Deze meetpaal was vanaf eind april 2019 volledig operationeel. De ontbrekende temperatuurgegevens voor de periode daarvoor in 2019 zijn aangevuld met een andere Rijkswaterstaatmeetpaal in het Markermeer die vergelijkbare watertemperaturen waarnam (Figuur 13). In 2020 zijn er temperatuurloggers geplaatst op bemonsteringslocaties op Marker Wadden. Voor het verloop van de watertemperatuur zijn de gegevens van de temperatuurlogger nabij het Aalscholverscherm (L2), gebruikt. De ondiepe wateren op Marker Wadden warmen sneller op en hebben grotere fluctuaties van dag tot dag (Figuur 13). In 2021 duurde het tot begin mei voordat de watertemperatuur structureel boven de 10 graden Celsius kwam in tegenstelling tot 2019 en 2020 . Het voorjaar kwam zeer langzaam op gang in 2021, begin april daalde de watertemperatuur zelfs tot onder de 7 graden. Begin mei schoot de watertemperatuur omhoog en in juni 2021 was het warmer dan de twee eerdere bemonsteringsjaren (Figuur 13).

De verschillen in windrichting en temperatuurverloop tussen de 3 jaren lijken hun weerslag te hebben gehad op de verschillen in soortsamenstelling en groei van vislarven (Bijlage 2 en 3). Aan de hand van de ontwikkelingen van 4 soorten, te weten blankvoorn, baars, snoekbaars en winde, worden de mogelijke effecten geïllustreerd (Figuur 13). Winde paait relatief vroeg bij watertemperaturen vanaf ca. $8^{\circ} \mathrm{C}$, baars vanaf ca $10^{\circ} \mathrm{C}$ en blankvoorn en snoekbaars vanaf ca $12^{\circ} \mathrm{C}$ (op basis van Kennisdocumenten SportvisserijNederland en literatuur daarin). In 2019 was de watertemperatuur eind maart waarschijnlijk al voldoende voor paai van winde, maar duurde het voor de andere soorten tot half april (baars) of eind april of mogelijk pas mei (blankvoorn en snoekbaars) voordat de omstandigheden geschikt werden. De westelijke wind van maart zorgde voor relatief hoog water op de ondiepe platen waar winde mogelijk kon paaien. De daaropvolgende aanhoudende oostelijke wind in april was mogelijk niet gunstig voor de andere soorten, en op ondieptes bij bijvoorbeeld het Aalscholverscherm (L2, L4, L5, L6, L9) werden dode volwassen (paairijpe) vissen aangetroffen, waaronder blankvoorn en snoek en snoekbaars, die wellicht verrast werden door de verandering in waterstand als gevolg van het draaien van de wind (paairijpe vis trekt vaak al ruim voor de eigenlijke paai naar geschikte paaiplekken). De veranderingen in waterniveaus in april en mei van 2019 moeten ook gezorgd hebben voor afstroom van water vanuit de ondiepe moerasandijvievelden (en bij de bruggen bij de haven werd aanzienlijke stroming geconstateerd!). Opvallend is dat alleen in 2019 veel windelarven werden aangetroffen en in 2020 en 2021 nauwelijks. Het kan zijn dat winde - die relatief vroeg paait en tot de stroomminnende soorten wordt gerekend - kon profiteren van de omstandigheden, zowel van de voorsprong met de temperatuurontwikkeling als de beschikbaarheid van geschikt habitat, terwijl die voor de andere soorten pas aanzienlijk later in mei ten goede keerden. Wellicht waren windelarven toleranter voor de in 2019 meer stromende condities ten gevolge van de draaiende wind. Wat ook opvalt is dat baars in 2019 pas laat (juni) werd waargenomen toen de larven/juvenielen al groter waren. Dit doet vermoeden dat baars elders heeft gepaaid en dat jonge baars in juni naar betreffende locaties is getrokken.

In 2020 steeg de watertemperatuur aanzienlijk in de eerste helft van april en dit zorgde er waarschijnlijk voor dat de vele soorten in een kort tijdsbestek konden paaien en in mei larven van de meeste soorten werden aangetroffen.

De lage watertemperaturen in het voorjaar van 2021 zorgden weer voor een latere paai en ontwikkeling van larven waarbij pas eind mei de eerste larven werden waargenomen en de aantallen piekten in juni. In juni 2021 zijn de waargenomen (gemiddelde) lengtes dan ook wat lager dan die in de twee voorgaande jaren. In augustus waren de waargenomen lengtes echter vergelijkbaar met die van 2019 en 2020. 

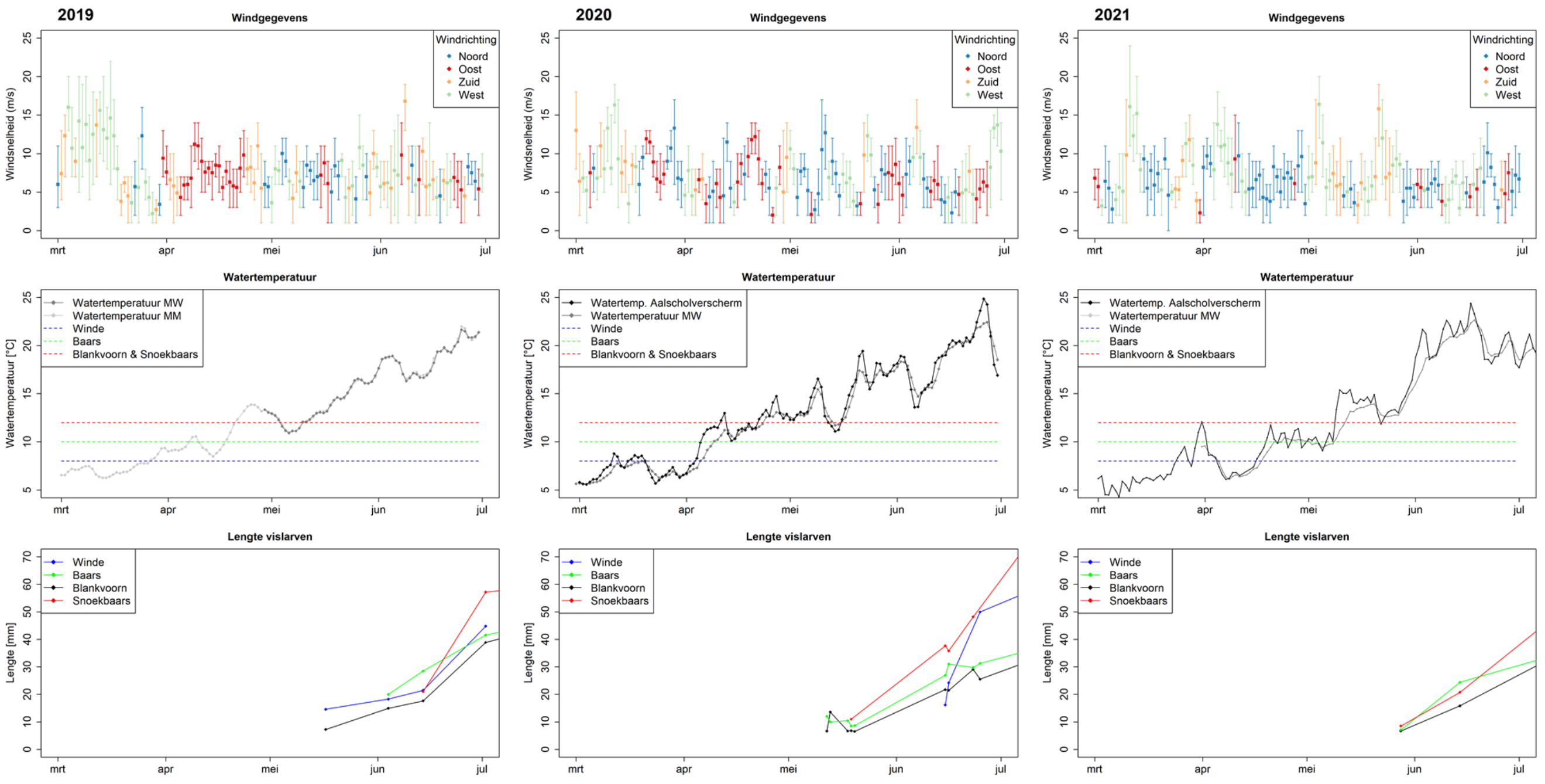

Figuur 13. Boven: Dominante windrichting en gemiddelde (inclusief minimum en maximum) windsnelheid [m/s] over een etmaal voor 2019 (links), 2020 (midden) en 2021 (rechts). Midden: Watertemperatuur op Marker Wadden (MW) of Markermeer (MM) zoals gemeten door de Rijkswaterstaatmeetpalen (grijs) en door een temperatuurlogger nabij het Aalscholverscherm (L2)(zwart). Stippel lijnen geven de drempelwaarde voor de start van de paai van winde (blauw), baars (groen) en blankvoorn (zwart) en snoekbaars (rood). Onder: Gemiddelde lengte van de gevangen vislarven door het seizoen heen. 


\subsection{Vis in fonteinkruidvelden westelijk Markermeer}

Om inzicht te krijgen in hoe de visstand in de luwte van de eilanden van Marker Wadden zich kan ontwikkelen bij de voortschrijdende ontwikkelingen in de vegetatie van onder meer fonteinkruid, en om te onderzoeken welke bemonsteringsmethode geschikt is voor het bemonsteren van fonteinkruidvelden, zijn van 3-5 juli 2018 fonteinkruidvelden in het westelijk Markermeer bemonsterd met respectievelijk de stortkuil, elektropuls draden en zegen (details in hoofdstuk 2 Methode). Hieronder worden de belangrijkste bevindingen beschreven.

De vegetatie bestond voornamelijk uit doorgroeid fonteinkruid met een enkele stengel aarvederkruid. $\mathrm{Er}$ is gevist in een range van dichtheid aan vegetatie door opeenvolgende trekken uit te voeren op een raai haaks op de oever. Velden van vele tientallen tot honderden meters wisselden af met dito stukken open water. Verder van de oever nam het aantal en de plantendichtheid van de velden af.

Stortkuil: Met de stortkuil werden 5 trekken van bijna 500 tot $1000 \mathrm{~m}$ afgelegd, dat wil zeggen door zowel vrij dichte velden als open plekken daartussen. Ondanks flinke golven (wind NO, 4 Bft) kon goed in span gevist worden. In alle trekken bleven flinke pollen waterplanten hangen aan de bovenreep, kuilgewichten en oorstokken, maar in de kuil zelf kwam nagenoeg geen plantenmateriaal terecht (Figuur 14). De vangsten waren in de ordegrootte van $10 \mathrm{~kg} / \mathrm{ha}$ en er werd bij iedere trek een verscheidenheid aan lengtes en vissoorten gevangen, met name snoekbaars, baars, blankvoorn en spiering en enkele alvers, windes en grondels.

Elektropuls draden: In de fonteinkruidvelden werd tegen de verwachting in geen enkele vis gevangen. Ook met het electrisch schepnet werd niets gevangen. Om uit te sluiten dat het apparaat niet goed werkte is een traject van 150 meter bevist in de haven van Edam langs de oever met stortsteen, riet en een veldje tenger fonteinkruid. Dit leverde wel vis op (onder meer baars en blankvoorn) wat bewijst dat het apparaat functioneerde. Vermoedelijk is de waterdiepte in de fonteinkruidvelden ( 2 tot ruim 3 meter) te groot om in open water efficiënt te kunnen vangen. Mogelijk speelde ook de wind en het zeer matige doorzicht (Secchi 0,4 tot 0,7m) een rol, waardoor eventuele vis die naar de pulsdraden wordt getrokken niet goed zichtbaar was.

Zegen: Met de zegen zijn 4 trekken op een raai haaks op de oever bevist in een range van vegetatie bedekking. De wind was vrijwel afwezig ( $N W,<2 \mathrm{Bft}$ ) en het doorzicht was 0,5 - $1 \mathrm{~m}$. Er werden slechts weinig planten bij gevangen omdat de zegen vrijwel steeds goed over de planten heen gleed: planten werden naar de bodem gedrukt maar kwamen na passage van het net weer omhoog. De vangsten waren geringer dan met de kuil, vergelijkbaar van samenstelling, maar bevatten minder spiering dan gevangen werd met de stortkuil. Het is mogelijk dat de spiering (en ook een deel andere vissen) als reactie op het toegenomen doorzicht naar dieper water is getrokken.

Waterplantvelden van fonteinkruid en aarvederkruid op enkele meters diepte kunnen dus zowel met de stortkuil als zegen bevist worden, waarbij per tijdseenheid meer vis wordt gevangen met de stortkuil dan met de zegen. 


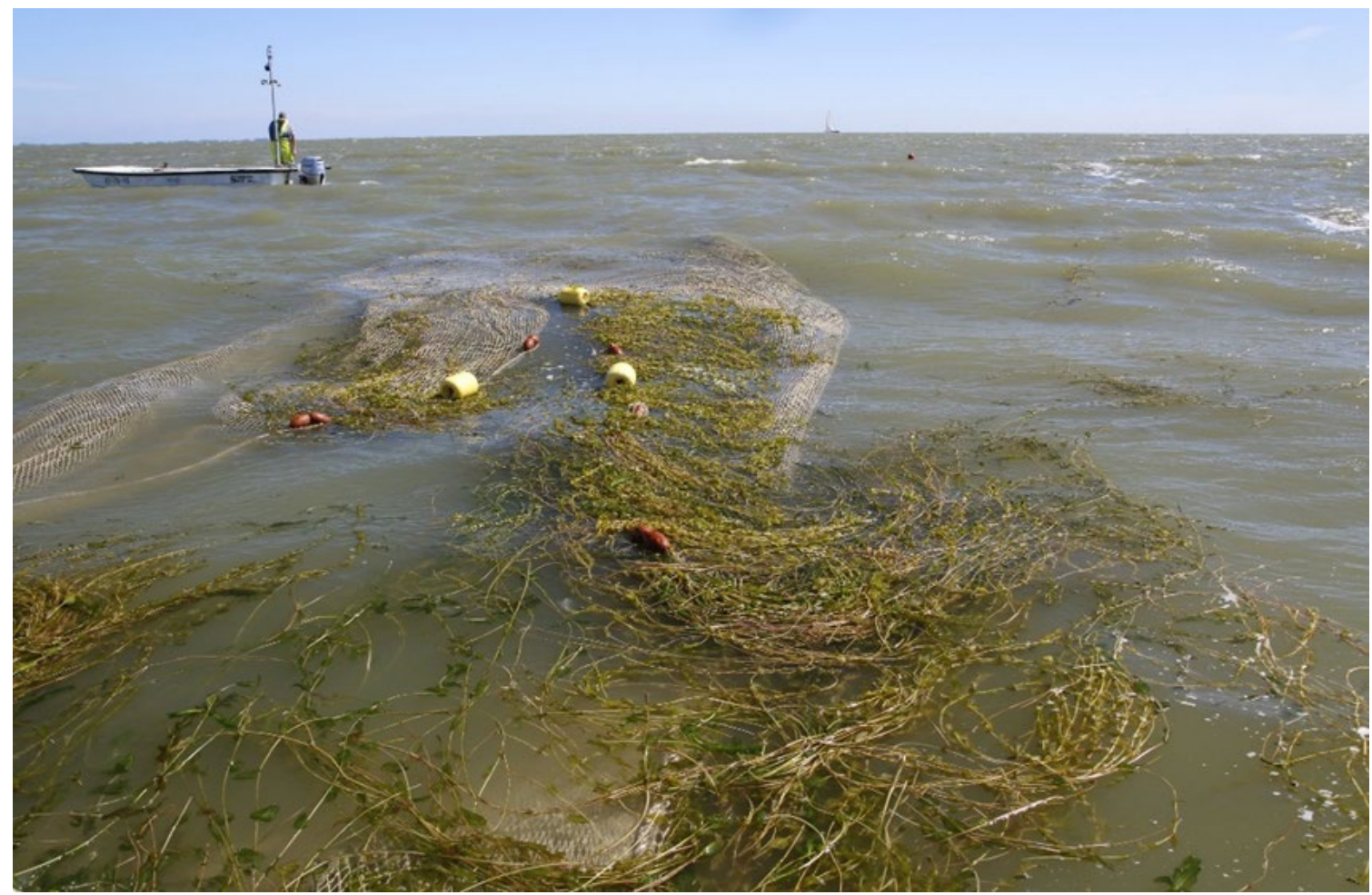

Figuur 14. Bij het vissen met de stortkuil vouwt fonteinkruid zich over de bovenreep van het net waarbij het net open (en dus visnamig) blijft. Foto: Joep de Leeuw.
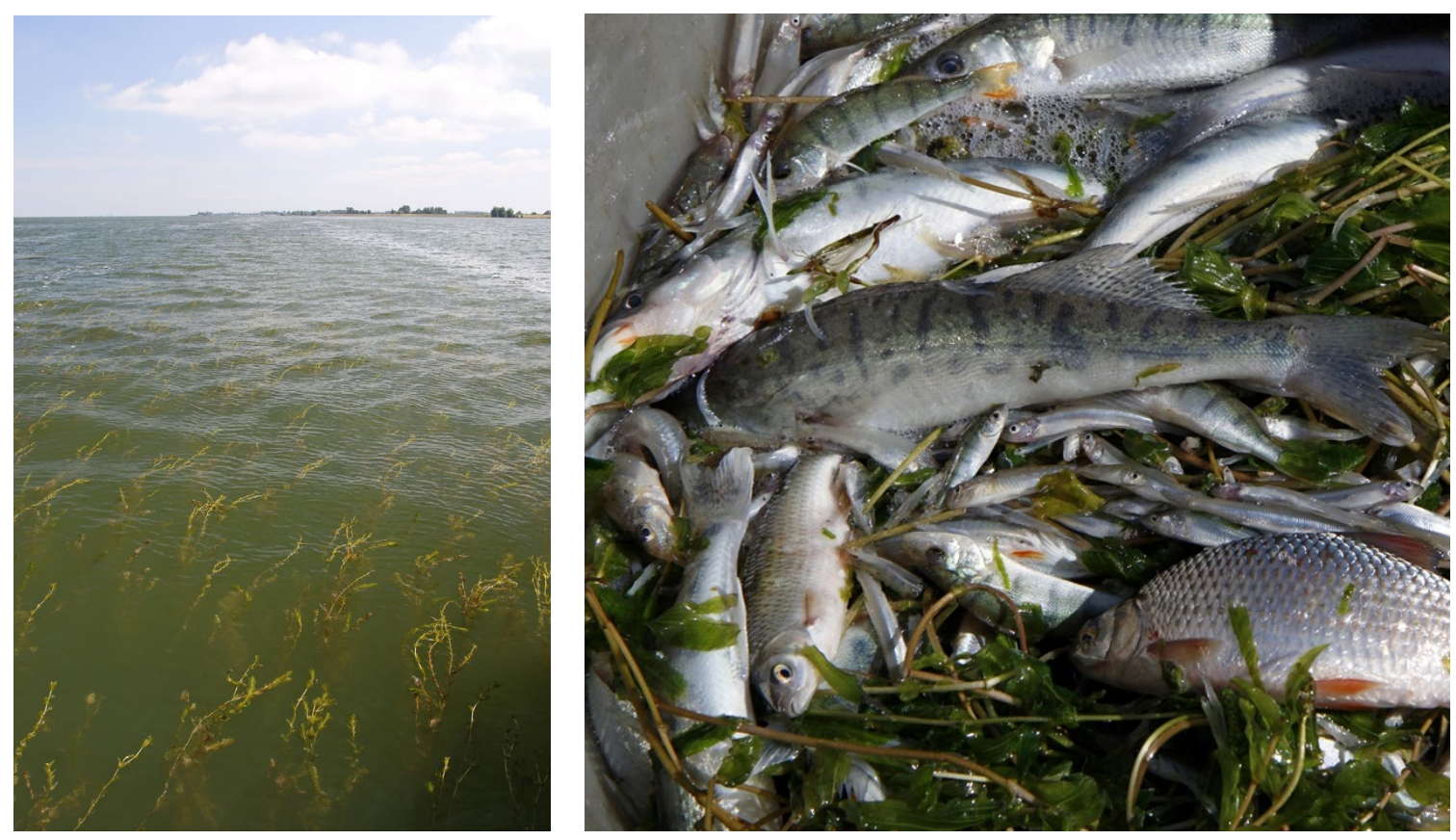

Figuur 15. Fonteinkruidvelden in het westelijk Markermeer (links) en vangst met de stortkuil (rechts), 3 juli 2018. Foto: Joep de Leeuw.

\subsection{Zandwinputten rond Marker Wadden}

In de 3 zandwinputten (1, 2 en 4 in figuur 16) werden met echosounding grote aantallen kleine vis waargenomen en verspreid (zowel horizontaal als verticaal) grote vis waargenomen (Figuur 17). In de slibgeul (3) werden geen vissen waargenomen. Met name in de diepste put (4) ten zuiden van de haven van het hoofdeiland werd veel vis waargenomen, tot op een diepte van ruim $30 \mathrm{~m}$. 


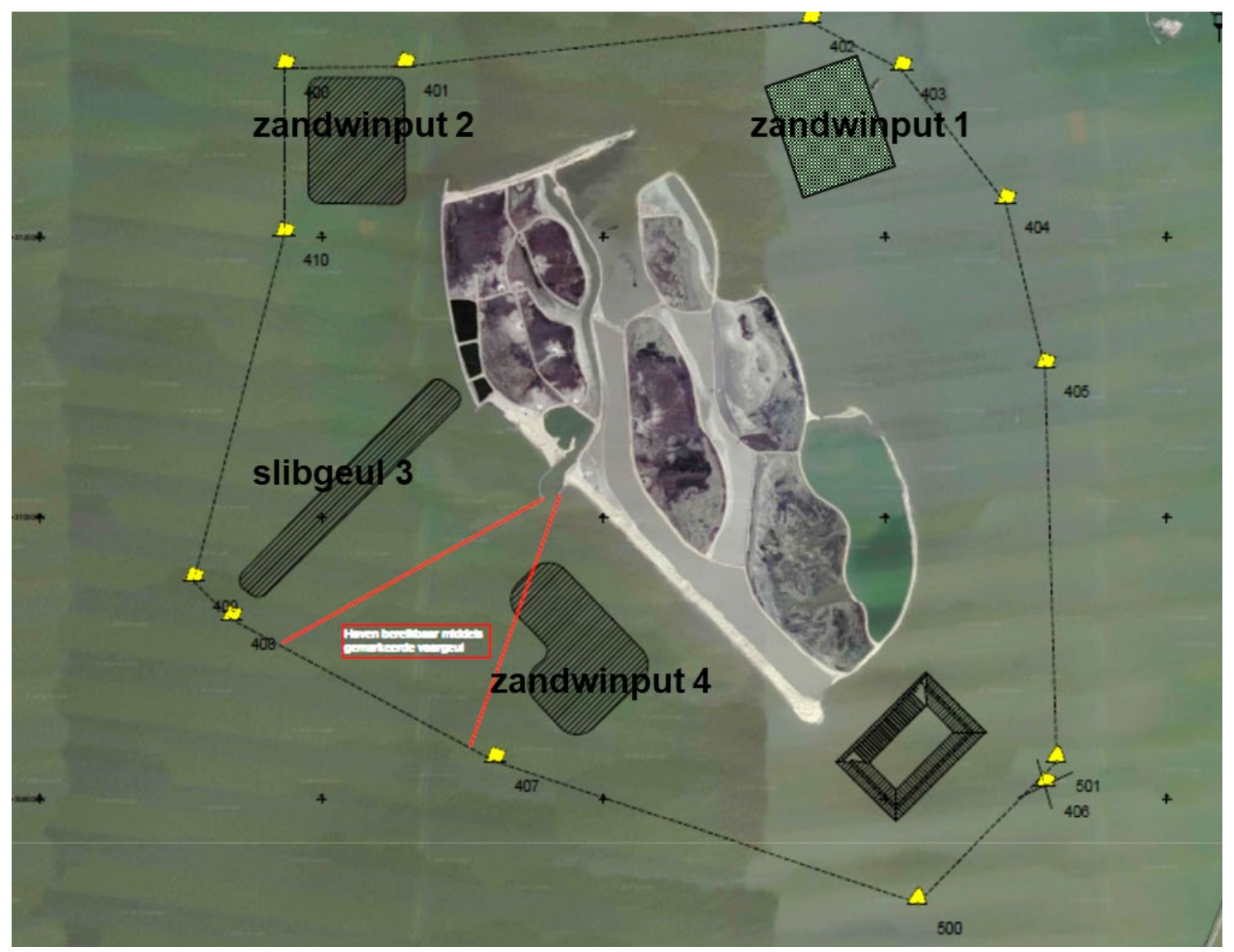

Figuur 16. Locaties bemonsterde zandwinputten en slibgeul rond Marker Wadden, augustus 2019.
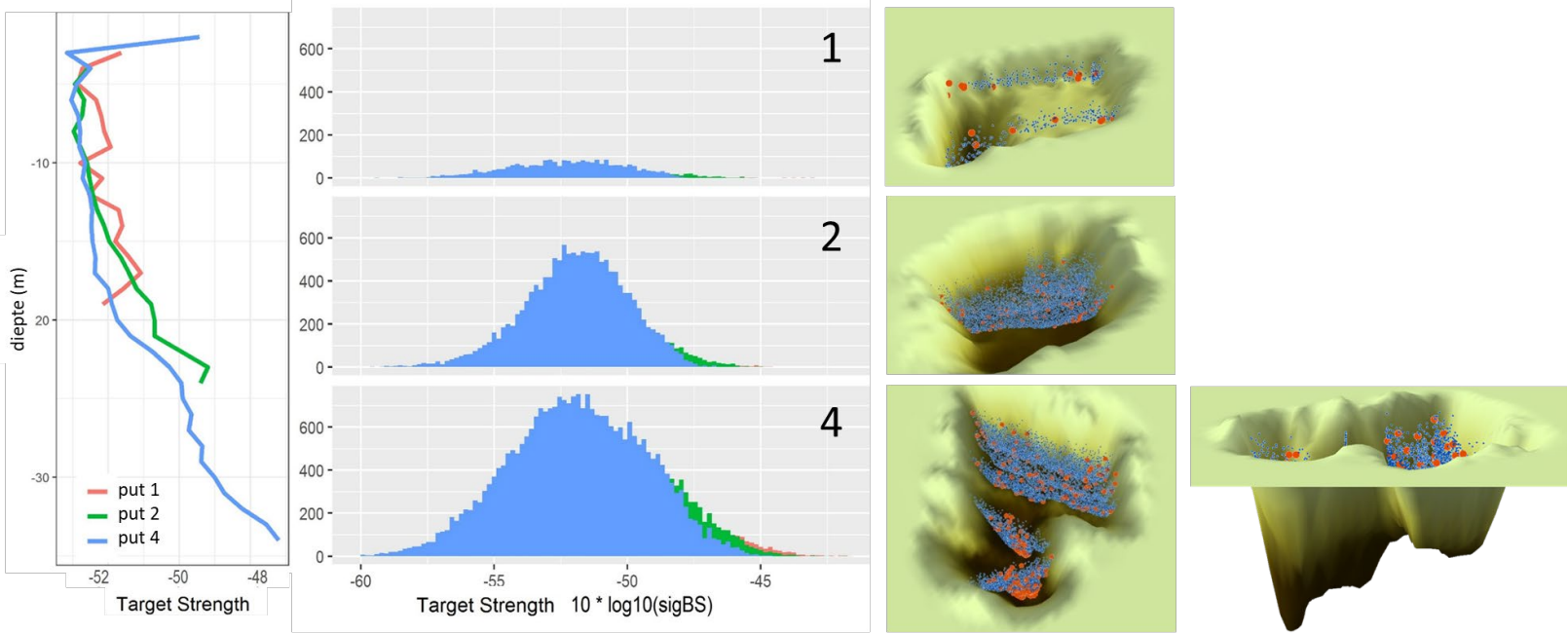

Figuur 17. Verdeling target strength (i.e. echosterkte) gemiddeld over de diepte (paneel links) en van individuele vissen (blauw=kleine, groen = middelgrote, rood=grote vissen) (midden en rechts) in drie zandwinputten, 20 augustus 2019 ( $n=46$ 000).

Vangsten met de 5-m A-toomkuil in dezelfde putten lieten zien dat het voornamelijk om spiering, pos en baars gaat (kleine vis) en snoekbaars (grote vis) (Figuur 18). 


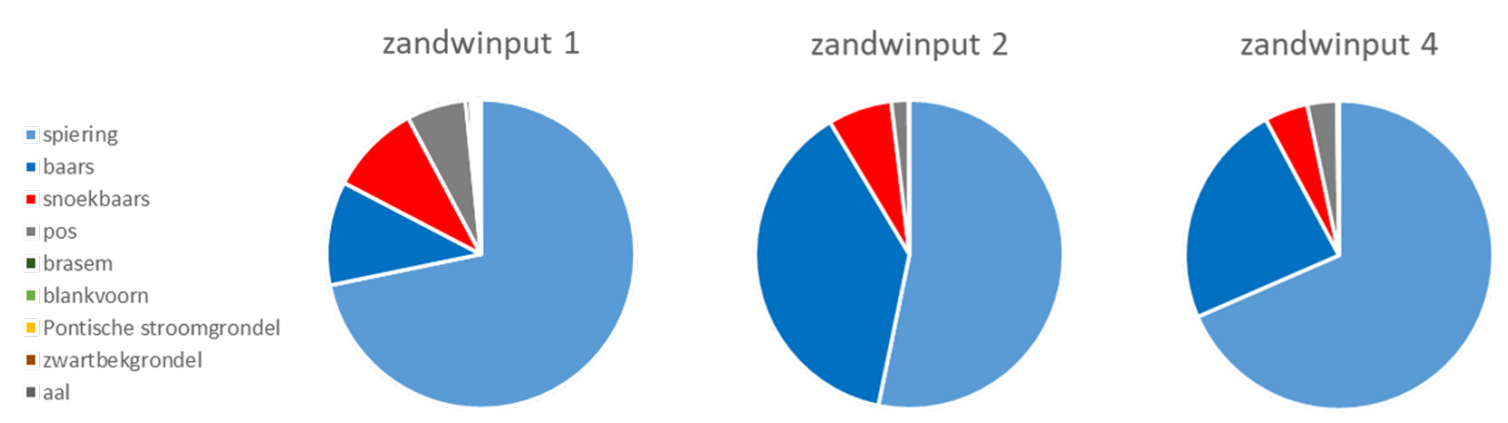

Figuur 18. Soortsamenstelling (\% aantal) van vangsten met een 5-m A-toomkuil op verschillende dieptes in 3 zandwinputten rond Marker Wadden, augustus 2019.

De meeste soorten werden verspreid over de hele waterkolom van de zandwinputten waargenomen (Tabel 1). Spiering en baars werden vooral in de bovenste waterlagen tot $10 \mathrm{~m}$ diepte waargenomen, terwijl snoekbaars, pos en grondels meer verspreid werden aangetroffen.

Tabel 1. Vangst met $5 m$-A-toomkuil, cpue $(\mathrm{n} / \mathrm{ha})$ in 3 zandwinputten rond Marker Wadden, aug 2019.

\begin{tabular}{lcccccc}
$\begin{array}{l}\text { diepte }(\mathrm{m}) \\
\text { zandwinput 1 }\end{array}$ & spiering & baars & snoekbaars & pos & $\begin{array}{c}\text { blankvoorn } \\
\text { / brasem }\end{array}$ & $\begin{array}{c}\text { grondels } \\
\text { / aal }\end{array}$ \\
\hline $5-10$ & 545 & 65 & 18 & 81 & 7 & 16 \\
$10-15$ & 360 & 112 & 38 & 27 & 27 & 13 \\
$\underline{\text { zandwinput 2 }}$ & & & & & & \\
$0-5$ & 914 & 644 & 25 & 0 & \\
$10-15$ & 36 & 38 & 12 & 16 & 4 \\
$15-20$ & 131 & 85 & 33 & 28 & \\
$\underline{\text { zandwinput 4 }}$ & & & & & \\
$7-12$ & 1462 & 652 & 21 & 63 & \\
$15-20$ & 234 & 46 & 15 & 25 & & 2 \\
$20-25$ & 40 & 18 & 12 & 48 & & 0
\end{tabular}




\section{Conclusies en aanbevelingen}

\subsection{Habitats voor paai en opgroei}

\subsubsection{Ontwikkeling soortenrijkdom}

In de periode 2018-2021 zijn 26 vissoorten vastgesteld op en rond Marker Wadden (Tabel 2). Het waargenomen aantal soorten per jaar neemt toe, hoewel niet alle soorten jaarlijks worden aangetroffen, vermoedelijk door toevalsfactoren. Naast de 26 rond Marker Wadden vastgestelde soorten werden in deze jaren in het Markermeer ook nog kolblei en bittervoorn waargenomen (Van Rijssel et al. 2021). Het lijkt niet meer dan een kwestie van tijd voordat deze soorten ook rond Marker Wadden zullen verschijnen, al zou voor bittervoorn, die voor de voortplanting afhankelijk is van zwanenmossels, dit wellicht iets langer kunnen duren.

Tabel 2. Vissoorten (ongeacht leeftijd) per jaar waargenomen in zomerbemonsteringen (dit rapport) en visstandbemonsteringen uitgevoerd in mei en september door Sportvisserij Nederland (Van Emmerik 2020a, 2020b, 2021) en vissoorten waarvan larven zijn aangetroffen gedurende de onderzoeksperiode 2018-2021.

\begin{tabular}{|c|c|c|c|c|c|}
\hline & 2018 & 2019 & 2020 & 2021 & larven \\
\hline Aal & $\mathrm{X}$ & $\mathrm{X}$ & $x$ & $\mathrm{X}$ & \\
\hline Bot & & & $\mathrm{X}$ & $x$ & \\
\hline Harder & & $x$ & & & \\
\hline Noordzeehouting & & $x$ & $x$ & $x$ & \\
\hline Spiering & $\mathrm{X}$ & $\mathrm{X}$ & $x$ & $\mathrm{X}$ & $*$ \\
\hline Pos & $\mathrm{X}$ & $\mathrm{X}$ & $x$ & $x$ & $*$ \\
\hline Baars & $x$ & $x$ & $\mathrm{X}$ & $\mathrm{X}$ & $*$ \\
\hline Snoekbaars & $\mathrm{X}$ & $x$ & $\mathrm{X}$ & $x$ & $*$ \\
\hline Snoek & & $\mathrm{X}$ & $\mathrm{X}$ & $x$ & \\
\hline Roofblei & $x$ & & & $x$ & \\
\hline Winde & $\mathrm{X}$ & $x$ & $\mathrm{X}$ & $\mathrm{X}$ & $*$ \\
\hline Alver & & $x$ & $\mathrm{X}$ & $\mathrm{X}$ & $*$ \\
\hline Driedoornige stekelbaars & $x$ & & $\mathrm{X}$ & $\mathrm{X}$ & $*$ \\
\hline Blankvoorn & $x$ & $\mathrm{X}$ & $x$ & $x$ & $*$ \\
\hline Brasem & $\mathrm{X}$ & $\mathrm{X}$ & $\mathrm{X}$ & $\mathrm{X}$ & $*$ \\
\hline Karper & $x$ & $x$ & $x$ & $x$ & $*$ \\
\hline Giebel & & $\mathrm{X}$ & & & \\
\hline Rietvoorn & & $x$ & & & \\
\hline Zeelt & & & & $x$ & \\
\hline Kleine modderkruiper & $x$ & & & $\mathrm{X}$ & $*$ \\
\hline Zwartbekgrondel & $\mathrm{X}$ & $\mathrm{X}$ & $\mathrm{X}$ & $\mathrm{X}$ & $*$ \\
\hline Pontische stroomgrondel & $\mathrm{X}$ & $\mathrm{X}$ & $\mathrm{X}$ & $\mathrm{X}$ & $*$ \\
\hline Marmergrondel & $x$ & $x$ & $x$ & $x$ & \\
\hline Kesslers grondel & $x$ & $x$ & $x$ & $x$ & \\
\hline Kaukasische dwerggrondel & & & & $\mathrm{X}$ & $*$ \\
\hline Europese meerval & & & $\mathrm{X}$ & & \\
\hline Aantal soorten & 16 & 18 & 20 & 22 & 14 \\
\hline
\end{tabular}


Van 14 soorten zijn (ook) larven waargenomen (Tabel 2) en er mag verondersteld worden dat deze soorten zich in de nieuw ontwikkelde habitats in de directe omgeving van Marker Wadden hebben voortgeplant. Het werkelijke aantal paaiende soorten is vermoedelijk al groter, maar van sommige soorten worden hoogstwaarschijnlijk larven gemist vanwege de beperkte bemonsteringsmogelijkheden, zowel wat betreft ontoegankelijkheid van habitats (instabiele bodems, steenoevers) als wat betreft het beperkte areaal dat jaarlijks bemonsterd kon worden ten opzichte van het totale oppervlak aan potentieel paaihabitat.

\subsubsection{Soortsamenstelling en habitatgebruik jonge vis}

Het onderzoek naar de opgroeigebieden van jonge vis laat een aantal opvallende overeenkomsten en verschillen zien tussen de drie bemonsterde jaren (2019-2021). In lijn met de verwachting (Van Emmerik \& Quak, 2021 en literatuur daarin) zijn de ondiepe habitats tussen de eilanden, met oeveren onderwatervegetatie, het rijkste aan jonge vis. Dit zijn de moerasandijvie- en rietvelden met de voeten in het water en de aangrenzende fonteinkruidvelden. Langs kale, zandige oevers is veel minder jonge vis aangetroffen en naarmate zandige oevers meer geëxponeerd lagen voor wind en golfslag werd er navenant minder vis aangetroffen.

Tussen de drie jaren werden echter aanzienlijke verschillen gevonden in soortsamenstelling en in de ontwikkeling over het seizoen. Hoewel blankvoorn in alle jaren de dominante soort was in mei, werd in 2019 ook veel winde aangetroffen, die in 2020 en 2021 weer vrijwel geheel ontbrak. Baars en pos paaien eerder dan blankvoorn, maar werden later in het zomerseizoen aangetroffen. Het is niet geheel duidelijk in welke mate deze soorten hier toch in de buurt paaiden of in de loop van het seizoen van elders kwamen.

De weersomstandigheden in het voorjaar verschilden aanzienlijk tussen de bemonsterde jaren, zowel wat betreft overheersende windrichting en windkracht als de temperatuurontwikkeling.

Watertemperatuurontwikkeling is van groot belang voor het paaisucces van verschillende soorten vanwege soortspecifieke verschillen in temperatuurgevoeligheid voor het moment van paaien (zie oog Figuur 13) en voor de groeisnelheid van jonge vis (o.a. Nõges \& Järvet 2005). Wind is van invloed op de golfslag en daarmee direct van invloed op de overleving van kwetsbare eieren en larven in de oeverzone (Čech et al. 2012). Wind en golfslag beïnvloeden ook de troebelheid van het water en daarmee indirect het voorkomen van zoöplankton (Jin 2021), de belangrijkste voedselbron van jonge vis. Ten slotte bepalen windkracht en windrichting ook het waterniveau. Een verandering van een aanhoudende windrichting, zoals in april/mei 2019, kan dan zorgen voor aanzienlijke waterniveauverschillen in korte tijd, en dus voor veel waterbewegingen waarbij ondiepe vlaktes leegstromen. Het kan zijn dat windelarven, als stroomminnende soort, beter bestand zijn tegen dergelijke stromende condities en daarom juist in 2019 relatief talrijk waren aan het begin van het seizoen. Ook bij Trintelzand werden windelarven juist daar aangetroffen waar de geul het grote binnenmoeras verbindt met het open water, dus waar bij kleine waterniveauverschillen relatief veel water wordt verplaatst en waar het dus een relatief stromend karakter heeft.

Hoewel de resultaten van het onderzoek naar paaigebieden sterk beïnvloed zijn door de weersomstandigheden, laten de resultaten een aantal aspecten zien die interessant zijn voor de inrichting en het beheer van het gebied. Het blijkt bijvoorbeeld dat luwe, ondiepe inhammen die in verbinding staan met het open water (dat wil zeggen toegankelijk zijn voor paairijpe vis), belangrijk zijn. Zeker als deze inhammen een flauw talud hebben, komt de vegetatieontwikkeling in de geleidelijke land-waterovergangen goed op gang. Deze gebieden lijken zich meerdere jaren achtereen te kwalificeren als goed paai- en opgroeigebied. De luwe inhammen blijken ook geschikt te zijn voor de ontwikkeling van onderwatervegetatie van met name fonteinkruid, kranswieren, aarvederkruid en Zannichellia (vooral in ondiep water tot ca 1 m; KIMA 2021) en voor macrofauna. Deze waterplantvelden bieden op hun beurt schuilgelegenheid en voedsel voor opgroeiende vis.

Daarbij is het goed om te realiseren dat genoemde habitats een zeer dynamische ontwikkeling gedurende het seizoen doormaken, zowel wat betreft de vegetatie boven als onder water (Figuur 19). De ontwikkeling van larven tot jonge vis gaat gepaard met verschuivingen in dieet naar geleidelijk aan 
grotere prooien, terwijl het habitat in die periode voortdurend verandert. Een hoge habitatdiversiteit met een mozaïek aan dieptezones en vegetatietypen biedt daarom variatie in temperatuur, voedsel en veiligheid waarin veel (soorten) jonge vis hun optimale omstandigheden op kunnen zoeken en goed op kunnen groeien.
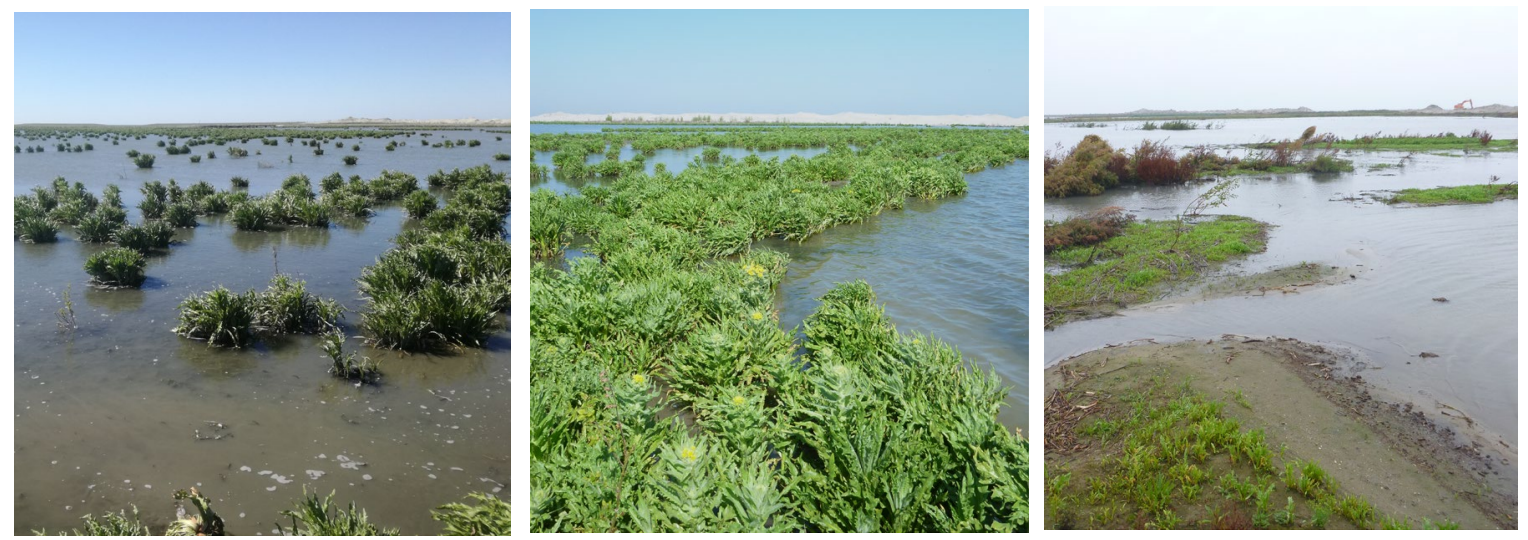

Figuur 19. Locatie 6 (kijkscherm Aalscholver). 10 april 2019, 19 april 2019, 26 september 2019

\subsubsection{Rol Marker Wadden in de jaarcyclus}

In dit onderzoek is vooral gekeken naar paai- en opgroeigebieden voor jonge vis. Door het jaar heen maken vissen op een grotere schaal gebruik van diverse habitats, afhankelijk van de fase in de jaarcyclus en levenscyclus. Hierbij kunnen oudere vissen zich anders gedragen dan jonge vissen.

Interessant hierbij is hoe vis op grotere schaal gebruik maakt van het Markermeer, het IJsselmeer en de omliggende gebieden. Van eerdere studies met individueel gemerkte vissen weten we dat ook gewone soorten als brasems zich over grote afstanden kunnen verplaatsen, bijvoorbeeld tussen winterrustplaatsen, paaigebieden en voedselgebieden in de zomer (De Leeuw et al. 2020). Ook van andere vissoorten waarbij volwassen dieren van zenders zijn voorzien bij Marker Wadden is bekend dat deze op grotere schaal een diversiteit aan habitats benutten, zowel diepe habitats (zoals zandwinputten) en de haven als ondiepe gebieden tussen de eilanden en andere oeverzones (Van Leeuwen et al., ongepubliceerd).

Vermoedelijk vormen de zandwinputten een relatief veilig habitat voor kleine vis, met driedimensionale ontsnappingsmogelijkheden voor roofvis en vogels door zich aan het zicht te onttrekken in de diepte. Bovendien bieden zandwinputten vermoedelijk een buffer tegen hoge watertemperaturen in warme zomerperioden, en een buffer tegen waterbewegingen bij stormachtig weer in rustperioden in het winterhalfjaar. Wellicht vormen de wanden van de put ook een voedselrijke bodem. Het voorkomen van kleine vis trekt vervolgens ook roofvis zoals snoekbaars aan en op hun beurt beroepsvissers die met staand want op snoekbaars vissen. 


\subsection{Verwachte ontwikkelingen jonge vis in oeverzones}

De oeverzones van Marker Wadden verkeren nog in een pioniersfase en zijn nog volop in ontwikkeling. Om een indruk te krijgen van welke ontwikkelingen in voorkomen van jonge vis bij verdere oeverontwikkeling te verwachten zijn, kunnen allereerst de visdichtheden rond Marker Wadden worden vergeleken met visdichtheden waargenomen in jaarlijkse bemonsteringen in augustus van oevers van het Markermeer (data WMR), en van augustus en september rond Marker Wadden (data WMR/NIOO en Sportvisserij Nederland) in 2020 en 2021 (Figuur 20). Daarbij moet opgemerkt worden dat de bemonsteringsmethoden deels verschillen (broedzegen of elektrisch schepnet) wat invloed kan hebben op de relatieve vangbaarheid van verschillende soorten. Ook is het belangrijk te realiseren dat de situatie in augustus/september een momentopname is (zie 4.2). Jonge vis verplaatst zich, dus reproductie (paai, larven) kan op andere plekken in de buurt plaatsvinden dan de habitatbenutting die later in de zomer (augustus) wordt waargenomen.

\section{Visdichtheden oeverhabitats}

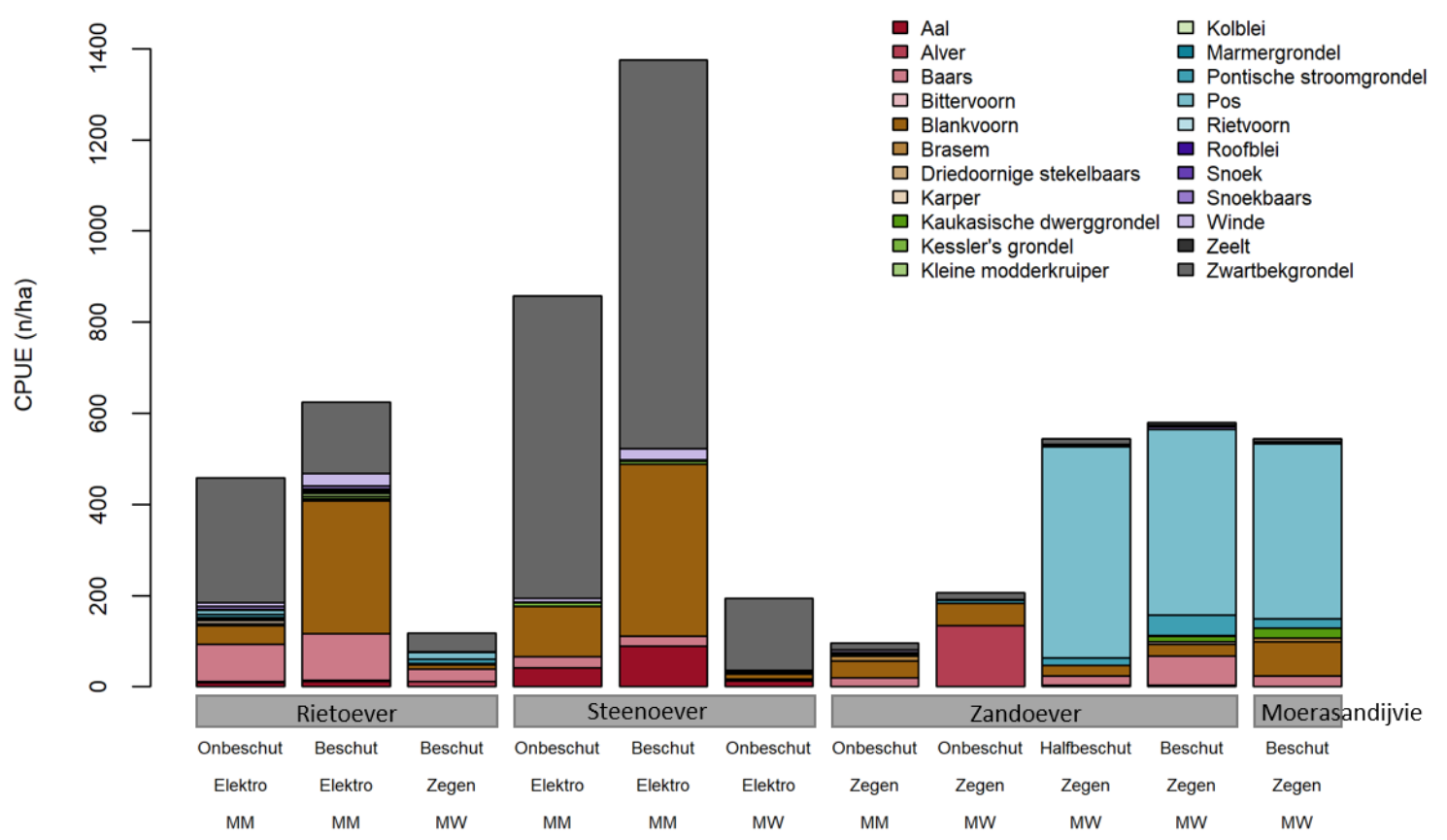

Figuur 20. Gemidelde visdichtheid (cpue) in verschillende typen oevers van Markermeer (Oeverbemonstering WMR, buitenzijde Marker Wadden (SVN) en tussen de eilanden (WMR/NIOO) in augustus/september 2020 en 2021. Bemonsteringen zijn uitgevoerd met een elektrisch schepnet (elektro) of broedzegen (zegen) in het Markermeer (MM) of op en rond Marker Wadden (MW).

Opvallend is echter dat langs de steenoevers van het Markermeer, die als het meest onnatuurlijke habitat worden gezien, in de nazomer de hoogste dichtheden jonge vis worden gevonden. Vangsten worden gedomineerd door jonge blankvoorn en zwartbekgrondel, maar ook aal (die zich overdag schuilhoudt tussen stenen maar goed vangbaar is met het elektrisch schepnet in tegenstelling tot met de broedzegen) komt in hoge dichtheden voor in de steenoevers. Ook voor de rietoevers bestaan de vangsten hoofdzakelijk uit blankvoorn en zwartbekgrondel en worden daarnaast hoge dichtheden baars gevonden. De soortdiversiteit is hoger dan langs steenoevers. Rond Marker Wadden is de lengte aan steenoevers (ca $5 \%$ ) en rietoevers ( $<2 \%$ ) nog zeer beperkt, en zijn de dichtheden jonge vis in deze habitats aanmerkelijk lager dan die in de oevers van het Markermeer. Bij de grotendeels onbeschutte zandoevers in het Markermeer wordt relatief weinig vis aangetroffen, maar rond Marker Wadden juist relatief veel in augustus, in het bijzonder langs de meer beschutte zandoevers. Hierbij is pos de dominante soort bij deze zandoevers, maar ook in de buurt van moerasandijvievelden, en komen daarnaast soorten als blankvoorn en baars relatief veel voor. Daarbij is het goed om te realiseren dat zandoevers van het Markermeer vaak snel overgaan in diep water of gebruikt worden voor recreatieve doeleinden, terwijl zandoevers van Marker Wadden natuurlijk en geleidelijk overgaan in ondiepe fonteinkruidvelden doordat tussen de eilanden veel gebieden (met uitzondering van de 
haven) aanzienlijk zijn opgevuld met zand en slib. Pos is een bodemlevende soort die het goed doet in het open water van het Markermeer en blijkbaar goed bestand is tegen de dunne sliblaag in het Markermeer. Ook tussen de eilanden van Marker Wadden komt veel min of meer gesuspendeerd dun slib voor, ook bij zandoevers en zandbodems. Naarmate meer slib ingevangen wordt in de bodem, door vegetatie en in zandwinputten, mag verwacht worden dat het aandeel van pos af zal nemen en soorten die beter gedijen in helderder plantenrijk water (baars, blankvoorn en vele andere soorten) meer de overhand zullen krijgen.

In het Markermeer bestaat ca. 65\% van de oeverlengte uit steenoevers (J. Volwater \& J.J. de Leeuw, ongepubliceerde data). In recente jaren is het aandeel zandoevers door natuurontwikkeling en andere werkzaamheden verviervoudigd tot ca. $19 \%$ van de oeverlengte van het Markermeer, terwijl rietoevers nu ca. $15 \%$ van de oevers beslaan. Marker Wadden heeft het Markermeer verrijkt met ruim $10 \%$ extra oeverlengte, die voor bijna $70 \%$ uit zandoevers bestaat, terwijl steenoevers (7\%) slechts een fractie uitmaken. Daarentegen bestaat ca. een kwart van de oevers van Marker Wadden uit moerasandijvie en een minieme fractie uit rietoevers. Opmerkelijk is dus dat in augustus/september het meest voorkomende oevertype ook de hoogste dichtheid jonge vis herbergt: steenoevers in het Markermeer en zandoevers rond Marker Wadden.

\subsection{Effecten Marker Wadden op visstand en vogels Markermeer}

De aanleg van Marker Wadden kan op verschillende manieren van invloed zijn op de ontwikkeling van de visstand in het Markermeer en op de voedselbasis van visetende vogels.

In voorgaande hoofdstukken is uitgebreid ingegaan op de ontwikkeling van oeverzones tussen de eilanden die fungeren als paai- en opgroeigebied voor vis, zowel wat betreft habitatdiversiteit als voedselproductie. Naar verwachting zullen de verdergaande ontwikkelingen richting voedselrijke en vegetatierijke moerasachtige oevers dus gunstig zijn voor de reproductiemogelijkheden van vis.

Dat betekent dat de lokale dichtheid van jonge vis in ondiep water toeneemt, wat gunstig kan zijn voor visetende vogels die Marker Wadden bezoeken. Het gaat daarbij zowel om wadende vogels als lepelaars en reigers die in de visrijke oeverzones terechtkunnen terwijl dat hoegenaamd niet mogelijk is langs de oevers van het Markermeer die grotendeels abrupt overgaan in diep water. Ook diverse soorten futen en oppervlaktejagers als sterns (visdief, reuzenstern, zwarte stern) en meeuwen kunnen profiteren van visrijke ondieptes.

Het is echter niet vanzelfsprekend dat met meer paaimogelijkheden door voedselrijke habitats op Marker Wadden ook de visstand in het hele Markermeer toeneemt. De vraag is namelijk of paaigebieden wel de beperkende factor zijn voor de dominante vissoorten van het Markermeer en niet de voedselbeschikbaarheid (zoöplankton en benthos), ofwel het functioneren van het voedselweb op de schaal van het hele Markermeer.

Indirect zou een ontwikkeling in de richting van een werkelijk grootschalig voedselrijk rietmoeras mogelijk wel een effect kunnen hebben op de productiviteit van het voedselweb, wanneer Marker Wadden bijvoorbeeld kunnen gaan functioneren als een koolstofbron voor benthosgemeenschappen in de wijde omtrek van Marker Wadden en daarmee de bodemproductiviteit verhogen (Van Riel et al. 2019, Verdonschot et al. 2020, 2021). Ook de luwtewerking van de eilanden kan een positief effect kunnen hebben op de trofische efficiëntie van het voedselweb, met name de benutting van algen door zoöplankton (Jin 2021, KIMA 2021), en daarmee ook hogerop in de voedselketen (zoöplankton $\rightarrow$ vis $\rightarrow$ vogels) de productie verhogen. Op dit moment is de schaal van productieve land-waterovergangen nog onvoldoende om effecten op het voedselweb van het Markermeer waar te nemen.

Marker Wadden en andere natuurontwikkelingsprojecten verkeren nog in een pionierssituatie en het zal nog de nodige tijd en beheerkeuzes vergen voordat de ontwikkeling van het gebied naar een 
voedselrijk rietmoeras de omvang heeft bereikt die het voedselweb van het Markermeer gunstig kan beïnvloeden.

Tot dusver zien we in de jaarlijkse vismonitoring van het Markermeer eerder het omgekeerde (Figuur 21). Met name in het open water is het bestand jonge vis sinds 2018 historisch laag, ook in vergelijking met het IJsselmeer waar zo'n dramatische terugval niet waarneembaar is. Ook in de oeverzones van het Markermeer werd de laatste jaren opvallend minder vis aangetroffen (Figuur 21). Tijdens de aanleg van vele zandige randen (Marker Wadden, Trintelzand, Houtribdijk, Almeerderstrand, Hoorn, IJburg 2) en baggerwerkzaamheden (zandputten en aanleg eilanden) lijken diverse populaties vissen te lijden te hebben van de activiteiten. Met name zooplanktoneters, jonge vis en soorten zoals spiering (Figuur 22), lijken nadeel te ondervinden van slibpluimen en een deel van de paaigebieden langs stenen dijken is verdwenen onder het zand. Daarnaast kunnen de werkzaamheden ook effect hebben gehad op de brasempopulatie, omdat brasems als bodemfaunaeter gebieden met hoge dichtheden zwavelbacteriën lijken te mijden (Verdonschot et al. 2020). Ook voor aal, waarvoor stenen oevers een belangrijk habitat vormen (zie 5.2) kan de aanleg van zandige randen op steenoevers in eerste instantie ongunstig uitpakken. Ten slotte zijn er zorgen over de chemische samenstelling van het voor de aanleg van onder meer Marker Wadden gebruikte slibmateriaal van elders. Of bovengenoemde denkbare effecten werkelijk bijgedragen aan een laag bestand jonge vis in de afgelopen jaren staat nog niet vast, maar het is raadzaam de mogelijkheid van dergelijke neveneffecten in overweging te nemen bij de planning van toekomstige natuurbouwactiviteiten. Een deel van deze effecten zal van voorbijgaande aard zijn, maar het zal de komende jaren nog onduidelijk blijven hoe de balans tussen verdergaande werkzaamheden en geleidelijke ontwikkeling van de nieuw aangelegde gebieden zich zal ontwikkelen en welke effecten dat zal hebben op de ontwikkelingen in de visstand op de schaal van het Markermeer.

Opmerkelijk is dat tegelijk met een laag bestand jonge vis in het Markermeer er de laatste jaren aanzienlijke vangsten van grote vis worden gerealiseerd in de beroepsvisserij op snoekbaars, aal en brasem. Het is mogelijk dat grote vissen echter indirect op bovengenoemde neveneffecten reageren. Voor brasem bestaat het vermoeden dat deze zich in delen van het Markermeer met veel zwavelbacteriën en weinig andere bodemfauna zich minder thuisvoelt en naar andere delen van het meer trekt, wellicht van open water naar oeverzones. Snoekbaars wordt veel waargenomen en gevangen bij zandwinputten waar ook jonge vis haar toevlucht zoekt en aal zou eveneens andere gebieden op kunnen gaan zoeken wanneer ze niet meer in een deel van de steenoevers terecht kunnen evenals hun voedsel (meestal jonge vis). Een hypothese is dus dat deze vissen zich elders concentreren waar ze mogelijk makkelijker vangbaar zijn voor de beroepsvisserij. 


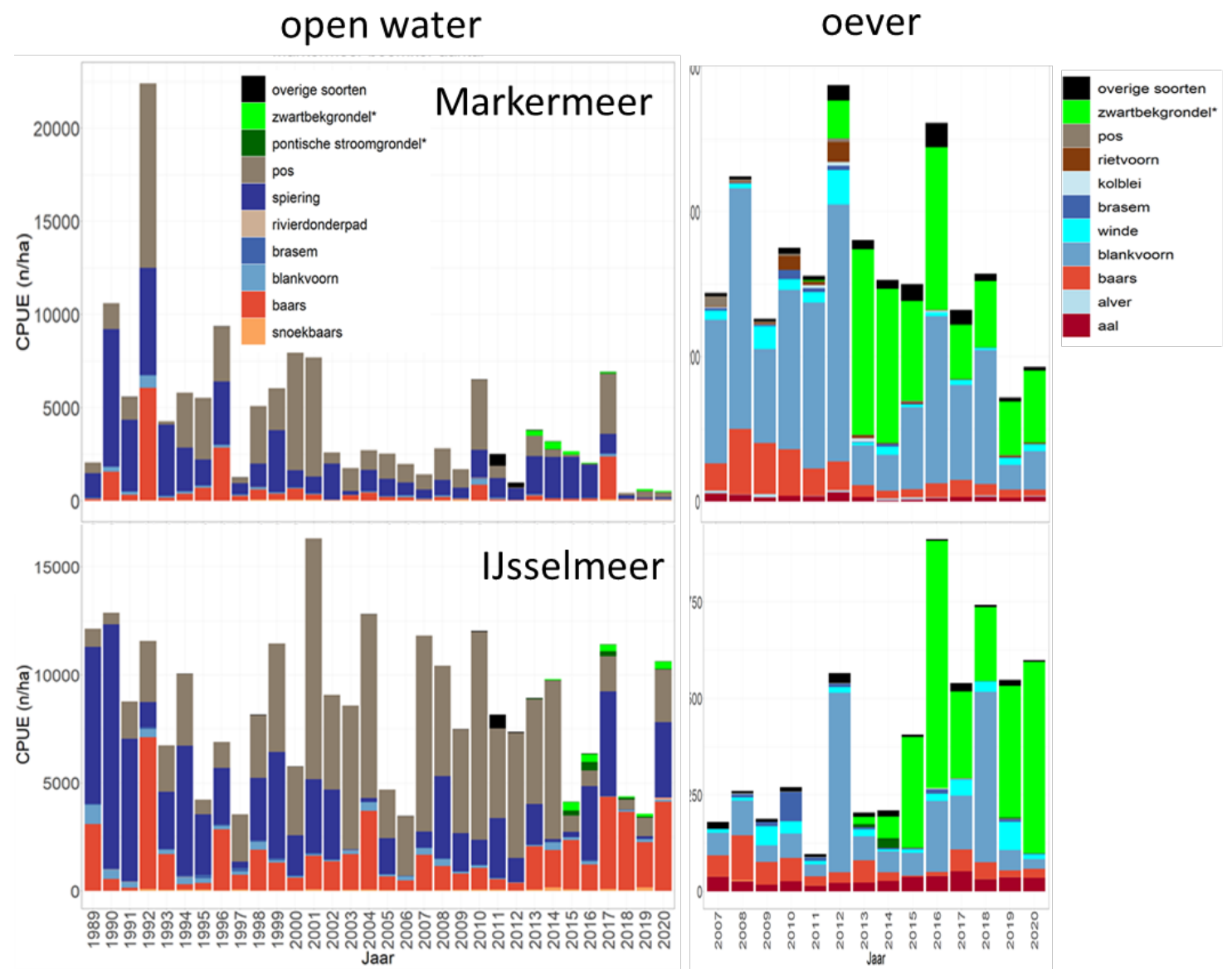

Figuur 21. Ontwikkelingen in de visstand (cpue, $n / h a$ ) in de gestandaardiseerde najaarsbemonstering van het open water met de boomkor (boven) en oevers (onder) in het Markermeer (links) en IJsselmeer (rechts). Bron: Van Rijssel et al. 2021.

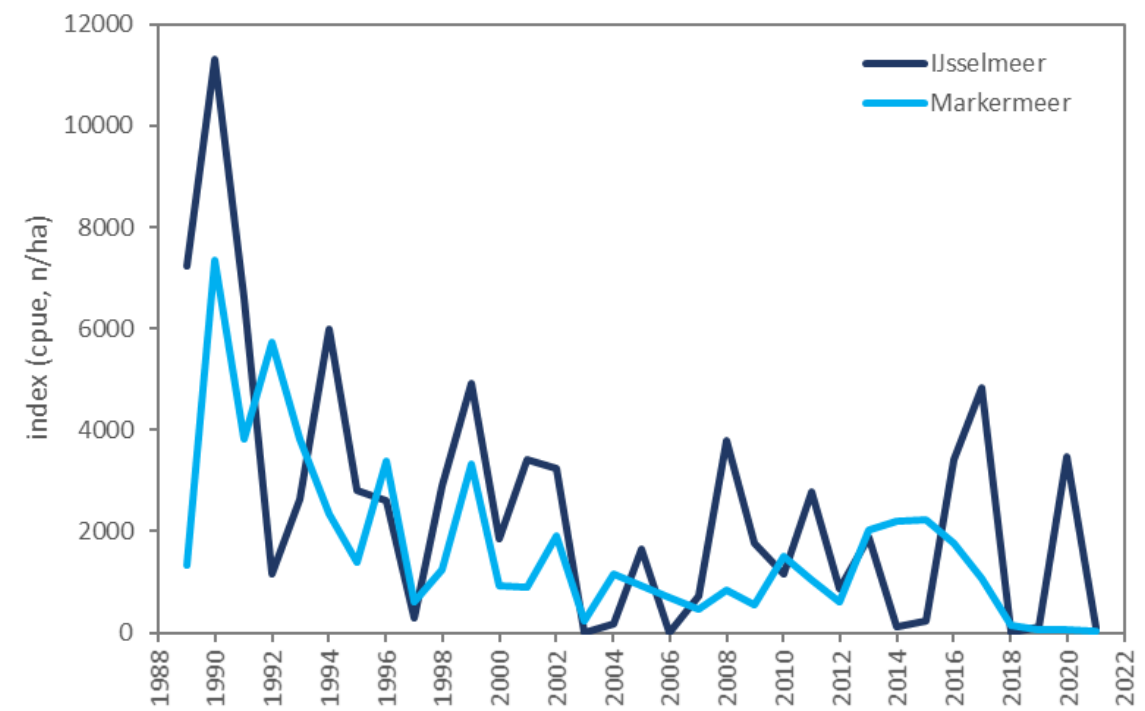

Figuur 22. Spieringindex op basis van gestandaardiseerde monitoring in het najaar met grote kuil/boomkor (De Leeuw et al. 2021). 


\subsection{Potentie Marker Wadden voor vis en vogels: beheer}

Er liggen grote kansen voor een verdere toename van de visstand, indien een aanmerkelijk groter deel van de luw gelegen oeverzones zich verder ontwikkelen naar plantenrijke inhammen en moerasvegetaties. Op dit moment zijn de ondiepe arealen met een rijke moerasvegetatie nog zeer beperkt. In hoeverre de zandwinputten een blijvende functie kunnen vervullen is niet geheel duidelijk. Deze fungeren als slibvang en hebben daarmee - als diepe put - een beperkte levensduur (ca. 50 jaar, KIMA 2021). Er is echter nog weinig bekend over de milieucondities in zandwinputten en de te verwachten ontwikkelingen daarin, net als over de mogelijke effecten daarvan voor de benutting van zandwinputten door vis.

Op termijn kan Marker Wadden uitgroeien tot een voedselrijk moeras met een zodanige omvang dat de effecten uitstralen op een groter gedeelte van het Markermeer. In dat geval kunnen de eilanden een katalyserende functie hebben als organische koolstofbron die bodemprocessen versterkt (Van Leeuwen et al. 2021, Van Riel et al. 2019, Verdonschot et al. 2021). Op dit moment is Marker Wadden hiervoor nog onvoldoende ontwikkeld. Dit wordt bevestigd door de waargenomen ontwikkeling van benthos in de land-waterovergangszones van Marker Wadden gedurende het seizoen, waarbij de ontwikkeling van benthos en aquatische macrofauna duidelijke seizoenspatronen laat zien met verschuivingen in taxonomische samenstelling (C.H.A. van Leeuwen et al., in prep). Wat dat betekent voor de voedselbeschikbaarheid voor vissen vereist verder onderzoek. Dit suggereert wel dat voor een meetbare functie als organische motor voor het Markermeer een aanzienlijke verdere ontwikkeling en rijping van een voedselrijk moeras nodig zou zijn.

Voor vissen is het van belang om een mozaïek te realiseren van ondiepe, brede, vegetatierijke landwaterovergangszones (voorjaar, jonge vis) met in de buurt diepere delen (1-2 m) met waterplanten (zomer) en diepere delen in de omgeving zoals haven en zandwinputten (najaar en winter). Belangrijk is de toegankelijkheid vanuit het open water, dus geleidelijke overgangen en voldoende diepe geulen voor grotere vis om zich in het voorjaar richting de ondieptes te wagen en veilig weer naar dieper water te keren.

Marker Wadden vormen een schakel in de verdere ontwikkeling van grootschalige, natuurlijke oevers. Elders langs de hele Houtribdijk zijn vooroevers opgespoten evenals de (schier)eilanden Trintelzand, terwijl plannen voor nieuwe projecten in de maak zijn. Ook bestaat het idee om verbindingen van het Markermeer naar de Oostvaarderplassen te maken. Deze achteroevers kunnen ook dienen als paai- en opgroeigebied. Een dergelijke achteroever is bij het IJsselmeer eerder al aangelegd in de Koopmanspolder.

In hoeverre rietmoerassen zich zullen ontwikkelen is voor een belangrijk deel een kwestie van beheerkeuzes die gemaakt moeten worden (KIMA 2021). Het tegennatuurlijke peilbeheer (hogere waterstanden in de zomer, lager in de winter) staat een natuurlijk ontstaan van grootschalig rietmoeras in de weg. Ook aanwezige herbivore vogels zoals ganzen verhinderen een snelle ontwikkeling van rietmoerassen (Temmink et al. 2022), maar het toestaan van wilgenopslag op specifieke locaties kan de vorming van rietmoerassen juist bevorderen. Ook zal de bodem van de eilanden verder inklinken en zonder maatregelen als bijvullen met zand en slib zullen grote delen van de eilanden onder water verdwijnen zoals bij het eilandje Ierst ten zuiden van Marker Wadden gaande is.

Omdat het gehele pakket aan maatregelen van zowel aanleg als gekozen beheer uiteindelijk bepalen in welke mate visbestanden deze op termijn zullen kunnen benutten, evenals de vogels die daarvan afhankelijk zijn, kent het beschrijven van de potenties voorlopig nog veel open einden. 


\subsection{Aanbevelingen}

Marker Wadden zijn nog volop in ontwikkeling en andere natuurontwikkelingsprojecten liggen in het verschiet. Zowel bij aanleg als beheer zijn vele varianten denkbaar en in omloop, terwijl de natuurlijke successie voortschrijdt. Het verdient aanbeveling om een uitgekiende lange-termijn monitoring van de visstand op te zetten met daarin een aantal vaste locaties (tijdreeksen van successie) en van een aantal habitats (locatie dynamisch in de tijd door successie en beheer). Door een dergelijke combinatie kan een vinger aan de pols worden gehouden hoe niet alleen bodemmateriaal en bedekking door planten in de oever en onderwater van invloed zijn op de functie als paai- en opgroeigebied, maar ook de interactie met de lange-termijn ontwikkeling van rijping van de bodem en van macrofaunaontwikkeling, en van een geleidelijk aan rijker wordende omgeving. Speciale aandacht verdient de zooplankton-ontwikkeling door het seizoen, omdat het succes van opgroei van vis afhangt van de successie van beschikbaar plankton (van rotiferen via copepoden naar cladoceren) gevolgd door bodemfauna (soorten als grondels, pos, karper, brasem), kleine vis (voor soorten als baars, snoekbaars, snoek, aal) en beschikbaarheid van zooplankton (voor planktivore soorten als spiering en alver). Daarnaast kan een dergelijke monitoring ook meer inzicht geven in de effecten van variatie in meteorologische omstandigheden op de ontwikkelingen en benuttingsmogelijkheden door vis en vogels. Dit alles kan houvast geven bij het begrijpen van de diversiteit van voedselbronnen en de veerkracht van het systeem en de verschillende beheerskeuzes die daarop van invloed zijn.

De benutting door vis van waterplantvelden tussen de eilanden (ondiep) en in de luwte van de eilanden (diep) is nauwelijks onderzocht. Op basis van ervaringen in het westelijk Markermeer kan een beperkte vismonitoring met stortkuil (eventueel met een zegen, mogelijk minder schade aan waterplantvelden) opgezet worden. Deze gebieden zijn mogelijk interessant voor zowel herbivore watervogels (zwanen, ganzen, eenden, meerkoeten) als voor visetende vogels (waaronder diverse soorten futen, sterns, en in ondiepe gebieden ook lepelaars en reigers). Het verdient daarbij aanbeveling om ook hier een directe link met bodemfauna-ontwikkeling te kunnen maken, zowel de productie als de diversiteit, die van groot belang kan zijn voor vis en vogels.

Aanvullend onderzoek naar de rol van zandwinputten voor vis en de levensduur van deze diepe putten bij dichtslibben is wenselijk. Resultaten van eerste onderzoeken lijken erop te duiden dat zandwinputten van aanzienlijke betekenis kunnen zijn voor vis, als refugium voor kleine vis wat vervolgens ook roofvis aantrekt, maar het is onduidelijk welke soorten of lengtegroepen door het jaar heen gebruik maken van deze putten. Ook is weinig bekend over de (veranderingen in) abiotische condities in zandwinputten en de mogelijke effecten daarvan op de benutting van zandwinputten door vis. Daarnaast is onduidelijk hoe het gebruik van zandwinputten door vis verandert over de jaren wanneer geleidelijk aan meer slib wordt ingevangen. Een sterk te adviseren benadering is een combinatie van monitoringsonderzoek in verschillende perioden van het jaar met echo-sounding en atoomkuil (hoeveel vis, welke soorten), abiotische metingen (waarom) en van telemetrie-onderzoek naar gedrag van individuele vissen (hoe hangt benutting zandwinputten ruimtelijk samen met die van andere habitats in de omgeving).

In het Markermeer is de afgelopen jaren een opvallende terugval waargenomen van het bestand jonge vis. Het is vooralsnog onvoldoende duidelijk wat de effecten van de vele werkzaamheden in het Markermeer daarop zijn. Een regelmatige monitoring van de fysische (bijvoorbeeld slibpluimen) en chemische samenstelling van het water alsmede de accumulatie van ecotoxische stoffen in vis kan hier meer inzicht in verschaffen en mogelijk bijdragen aan een natuur- en milieuvriendelijke planning van natuurbouwwerkzaamheden.

Een nadere uitwerking van het belang en de functie van verschillende typen oeverhabitats en landwaterovergangen voor vissen op de schaal van het gehele Markermeer kan de rol van Marker Wadden in breder perspectief plaatsen. Hierbij zou ook de opgedane kennis met betrekking tot ontwikkelingen rond De Kreupel en Ierst meegenomen kunnen worden. Gezien de hoge dichtheden vis die langs steenoevers (ca. 65\% van oevers in het Markermeer) worden waargenomen, is het zinvol om meer inzicht te krijgen in welke functie dit habitattype heeft. Onbekend is in hoeverre steenoevers grootschalig benut worden voor reproductie (paai, larven), opgroei van juveniele vis of foerageerhabitat voor adulte vis en welke rol steenoevers spelen als respectievelijk paaisubstraat, 
schuilmogelijkheden tussen stenen, en voedselbron (substraat voor aangroei van plantaardig en dierlijk benthos). Hierbij kan de mate van blootstelling aan windeffecten (beschut of onbeschut) ook een belangrijke factor zijn. Een beperkt bemonsteringsprogramma in het voorjaar en de zomer kan hierover al veel informatie verschaffen.

Het Markermeer en IJsselmeer zijn communicerende vaten voor vogels en vissen. De bijdrage van natuurontwikkelingsprojecten als Marker Wadden aan de visstand en aantallen vogels die daarvan afhankelijk zijn in het Markermeer en IJsselmeer kan alleen worden begrepen wanneer de samenhang op grotere landschapsschaal in ogenschouw wordt genomen. Het verdient daarom aanbeveling om de kennisinfrastructuur, monitoring en onderzoek uit de vele lopende en geplande projecten op die landschapsschaal op elkaar af te stemmen. 


\section{Kwaliteitsborging}

Wageningen Marine Research beschikt over een ISO 9001:2015 gecertificeerd

kwaliteitsmanagementsysteem. De organisatie is gecertificeerd sinds 27 februari 2001. De certificering is uitgevoerd door DNV. 


\section{Literatuur}

Čech, M., J. Peterka, M. Říha, L. Vejř́ík, T. Jůza, M. Kratochvíl, V. Draštík, M. Muška, P. Znachor, J. Kubečka, 2012. Extremely shallow spawning of perch (Perca fluviatilis L.): the roles of sheltered bays, dense semi-terrestrial vegetation and low visibility in deeper water. Knowledge and Management of Aquatic Ecosystems 406: 09p1-09p12. DOI: 10.1051/kmae/2012026.

De Leeuw, J.J., O. van Keeken, C. Meeldijk, M. Poot 2020. Beschikbaarheid van vis voor visdieven rond Marker Wadden in juli 2020. Wageningen Marine Research rapport C099/20.

https://doi.org/10.18174/535076

De Leeuw, J.J. \& W.A.M. van Emmerik 2019. Vis rond de Marker Wadden. Visionair 54: 18-21.

De Leeuw, J. \& C. van Leeuwen 2010. Visparadijs Marker Wadden. Presentatie en workshop KIMAsymposium 2020.

De Leeuw, J.J., O. Van Keeken, H.V. Winter 2020. Migratiestudie brasem in het IJsselmeergebied in 2020. Wageningen Marine Research rapport C086/20. https://doi.org/10.18174/532651.

Elings, J. 2019. The Marker Wadden. Pioneering with fish spawning. Student trainee presentation/report, Wageningen University

Jin, H. 2021. Restoring aquatic food webs bottom-up: Improving trophic transfer through lake restoration project Marker Wadden. Proefschrift, Wageningen University.

Kampen, J. 2018. Veldverslag pilot bemonstering vegetatievelden Markermeer. Atkb Adviesbureau voor water, bodem en ecologie. Notitie 20180631/not01.

Kennisdocumenten Blankvoorn, winde, baars, snoekbaars. Sportvisserij Nederland, Bilthoven.

KIMA, 2021 (concept). Rapportage over de eerste vijf jaar onderzoek op Marker Wadden. Synthese rapport KIMA.

Nõges, P \& A. Järvet 2005. Climate driven changes in the spawning of roach (Rutilus rutilus L. ) and bream (Abramis brama L.) in the Estonian part of the Narva river basin. Boreal Environment Research 10: 45-55.

Temmink, R.J.M., M. van den Akker, C.H.A.van Leeuwen, Y. Thöle, H. Olff, V.C.Reijers, S.T.J. Weideveld, B.J.M. Robroek, L.P.M. Lamers, E.S.Bakker 2022. Herbivore exclusion and active planting stimulate reed marsh development on a newly constructed archipelago, Ecological Engineering 175, https://doi.org/10.1016/j.ecoleng.2021.106474.

Van Eerden, M.R., H. Bos, L. van Hulst, 2007. In the mirror of a lake. Peipsi and IJsselmeer for mutual reference. Rijkswaterstaat Centre of Water Management, Regional Directorate IJsselmeergebied, Lelystad. ISBN 9789036914710.

Van Emmerik, W.A.M., 2020a. Vismonitoring Marker Wadden. Rapport 2019. Sportvisserij Nederland, Bilthoven.

Van Emmerik, W.A.M., 2020b. Vismonitoring Marker Wadden. Rapport 2020. Sportvisserij Nederland, Bilthoven. 
Van Emmerik, W.A.M., 2021. Vismonitoring Marker Wadden. Rapport 2021. Sportvisserij Nederland, Bilthoven.

Van Emmerik, W.A.M. \& J. Quak, 2020. Functies van land-waterovergangen voor vissen. Sportvisserij Nederland, Bilthoven.

Van Leeuwen, C.H.A., Temmink, R.J.M., Jin, H., Kahlert, Y., Robroek, B.J.M., Berg, M.P., Lamers, L.P.M., van den Akker, M., Posthoorn, R., Boosten, A., Olff, H., \& Bakker, E.S. 2021. Enhancing ecological integrity while preserving ecosystem services: Constructing soft-sediment islands in a shallow lake. Ecological Solutions and Evidence, 2 [e12098]. https://doi.org/10.1002/26888319.12098.

Van Riel, M.C., J.A. Vonk, R. Noordhuis, \& P.F.M. Verdonschot (2019). Novel ecosystems in urbanized areas under multiple stressors: Using ecological history to detect and understand ecological processes of an engineered ecosystem (lake Markermeer). Notitie Zoetwaterecosystemen, Wageningen Environmental Research, Wageningen UR, Wageningen. 34 pp.

Van Rijssel, J.C., O.A. van Keeken, en J.J. de Leeuw, 2021. Vismonitoring Rijkswateren t/m 2020. Deel 1: Toestand en trends. Wageningen Marine Research rapport C096/21.

Verdonschot P.F.M., Noordhuis, R. Volwater J.J.J., de Leeuw J.J. \& van Riel M.C. , 2020. Het bodemvoedselweb in het Markermeer? Over de rol van zwavelbacteriën - wormen - brasem. Notitie Zoetwaterecosystemen, Wageningen Environmental Research, Wageningen UR, Wageningen. 25 pp.

Verdonschot, P.F.M., M.C. van Riel \& R.C.M. Verdonschot 2021. Gezond bodemleven als sleutel voor een robuust Markermeer. Landschap 38: 16-23 


\section{Verantwoording}

Rapport C058/21

Projectnummer: 4316100261

Dit rapport is met grote zorgvuldigheid tot stand gekomen. De wetenschappelijke kwaliteit is intern getoetst door een collega-onderzoeker en het verantwoordelijk lid van het managementteam van Wageningen Marine Research

Akkoord:

Isabelle van der Ouderaa

onderzoeker

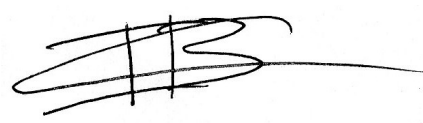

Datum:

25-1-2022

Akkoord:

Drs. Jakob Asjes

Mt lid Integratie

Handtekening:

Datum:

26-1-2022 


\section{Bijlage 1 Bemonsteringen 2019-2021}

Tabel B1. Bemonsteringsdagen in 2019 en 2020. Niet alle locaties zijn per bemonsteringsdag bevist.

\begin{tabular}{|c|c|c|c|}
\hline Maand & 2019 & 2020 & 2021 \\
\hline Maart & $\begin{array}{l}19-\mathrm{mrt} \\
28-\mathrm{mrt}\end{array}$ & & \\
\hline April & $\begin{array}{l}\text { 10-apr } \\
\text { 19-apr }\end{array}$ & & \\
\hline Mei & $\begin{array}{l}\text { 3-mei } \\
\text { 17-mei }\end{array}$ & $\begin{array}{l}\text { 12-mei } \\
13-m e i \\
18-m e i \\
20-m e i\end{array}$ & $\begin{array}{c}6 \mathrm{mei} \\
28 \mathrm{mei}\end{array}$ \\
\hline Juni & $\begin{array}{l}\text { 4-jun } \\
\text { 14-jun }\end{array}$ & $\begin{array}{l}15 \text {-jun } \\
16 \text {-jun } \\
23 \text {-jun } \\
25 \text {-jun }\end{array}$ & 14 juni \\
\hline Juli & 2-jul & $\begin{array}{l}10-j u l \\
13-j u l \\
17-j u l\end{array}$ & 13 juli \\
\hline Aug & & $\begin{array}{l}10 \text {-aug } \\
12 \text {-aug }\end{array}$ & 10 aug \\
\hline Sept & 26-sep & 10-sep & \\
\hline
\end{tabular}

Tabel B2. Overzicht van het aantal uitgevoerde vistrekken in 2019 per maand per habitat met de twee gebruikte vistuigen; schepnet (larvennet en RAVON-net) en zegen.

\begin{tabular}{c|lccc} 
Maand & Vistuig & Moerasandijvie & Rietoever & $\begin{array}{c}\text { Zandoever } \\
\text { onbeschut }\end{array}$ \\
\hline \multirow{2}{*}{ Maart } & Schepnet & 7 & 6 & 1 \\
& Zegen & - & - & - \\
\hline \multirow{2}{*}{ April } & Schepnet & 6 & 3 & 3 \\
& Zegen & - & - & - \\
\hline \multirow{2}{*}{ Mei } & Schepnet & 8 & 3 & - \\
& Zegen & 1 & 1 & - \\
\hline \multirow{2}{*}{ Juni } & Schepnet & 15 & 5 & - \\
& Zegen & - & - & - \\
\hline \multirow{2}{*}{ Juli } & Schepnet & 2 & 4 & - \\
& Zegen & 6 & 2 & - \\
\hline \multirow{2}{*}{ September } & Schepnet & - & 1 & - \\
& Zegen & 3 & 2 & - \\
\hline
\end{tabular}


Tabel B3. Overzicht van het aantal uitgevoerde vistrekken in 2020 per maand per habitat met de twee gebruikte vistuigen; schepnet (larvennet en ravonnet) en zegen.

\begin{tabular}{c|lccccc}
\multirow{2}{*}{ Maand } & Vistuig & Moerasandijvie & Rietoever & $\begin{array}{c}\text { Zandoever } \\
\text { beschut }\end{array}$ & $\begin{array}{c}\text { Zandoever } \\
\text { halfbeschut }\end{array}$ & $\begin{array}{c}\text { Zandoever } \\
\text { onbeschut }\end{array}$ \\
\hline \multirow{2}{*}{ Mei } & Schepnet & 7 & 2 & 4 & 3 & 4 \\
& Zegen & - & - & - & & - \\
\hline \multirow{2}{*}{ Juni } & Schepnet & 14 & 4 & 8 & 6 & 8 \\
& Zegen & 3 & 2 & 4 & 3 & 3 \\
\hline \multirow{2}{*}{ Juli } & Schepnet & 7 & 2 & 4 & 3 & 4 \\
& Zegen & 3 & 2 & 4 & 3 & 3 \\
\hline \multirow{2}{*}{ Augustus } & Schepnet & 7 & 2 & 4 & 3 & 3 \\
& Zegen & 3 & 2 & 4 & 3 & - \\
\hline \multirow{2}{*}{ September } & Schepnet & - & - & - & - & 3 \\
& Zegen & 2 & 4 & 7 & 5 & \\
\hline
\end{tabular}

Tabel B4. Overzicht van het aantal uitgevoerde vistrekken in 2021 per maand per habitat met de twee gebruikte vistuigen; schepnet (larvennet en RAVON-net) en zegen (broedzegen en larvenzegen).

\begin{tabular}{|c|c|c|c|c|c|}
\hline Maand & Vistuig & Moerasandijvie & Rietoever & $\begin{array}{l}\text { Zandoever } \\
\text { beschut }\end{array}$ & $\begin{array}{l}\text { Zandoever } \\
\text { halfbeschut }\end{array}$ \\
\hline \multirow{2}{*}{ Mei } & Schepnet & 8 & 8 & 8 & 8 \\
\hline & Zegen & 4 & 4 & 4 & 4 \\
\hline \multirow{2}{*}{ Juni } & Schepnet & 4 & 4 & 4 & 4 \\
\hline & Zegen & 3 & 4 & 4 & 4 \\
\hline \multirow{2}{*}{ Juli } & Schepnet & 2 & 2 & 2 & 2 \\
\hline & Zegen & 1 & 2 & 2 & 2 \\
\hline \multirow{2}{*}{ Augustus } & Schepnet & - & - & - & - \\
\hline & Zegen & 1 & 2 & 2 & 2 \\
\hline \multirow{2}{*}{ September } & Schepnet & - & - & - & - \\
\hline & Zegen & - & - & - & - \\
\hline
\end{tabular}




\section{Bijlage 2 Lengteverdelingen per soort}

\section{B2.1 Baars}
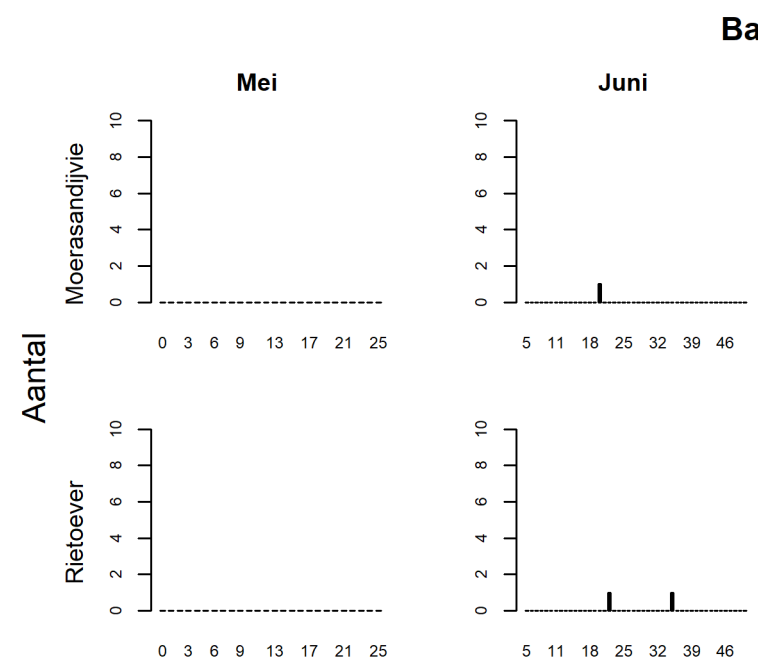

Baars 2019
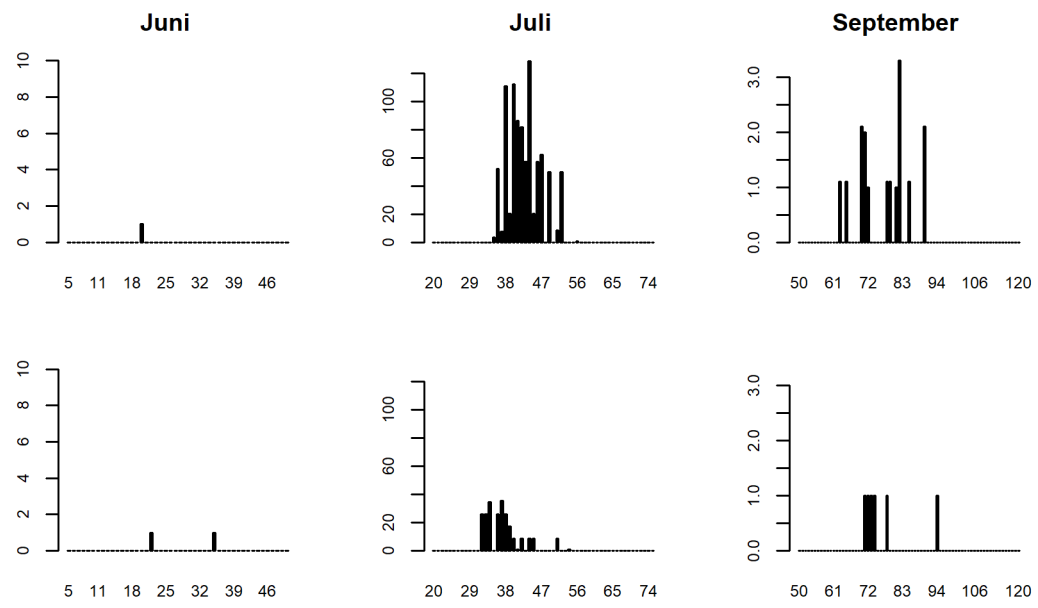

Lengte in $\mathrm{mm}$

Figuur B2.1. Lengte-frequentie (in $\mathrm{mm}$ ) grafieken van baars per maand en per bemonsterd habitat (moerasandijvie en rietoever) in 2019. 

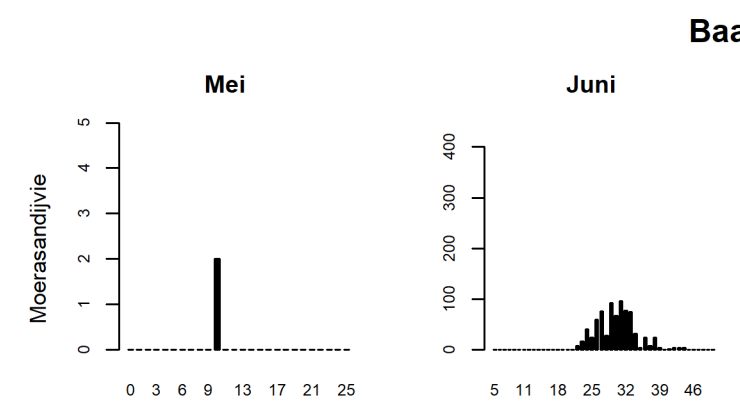

Baars 2020
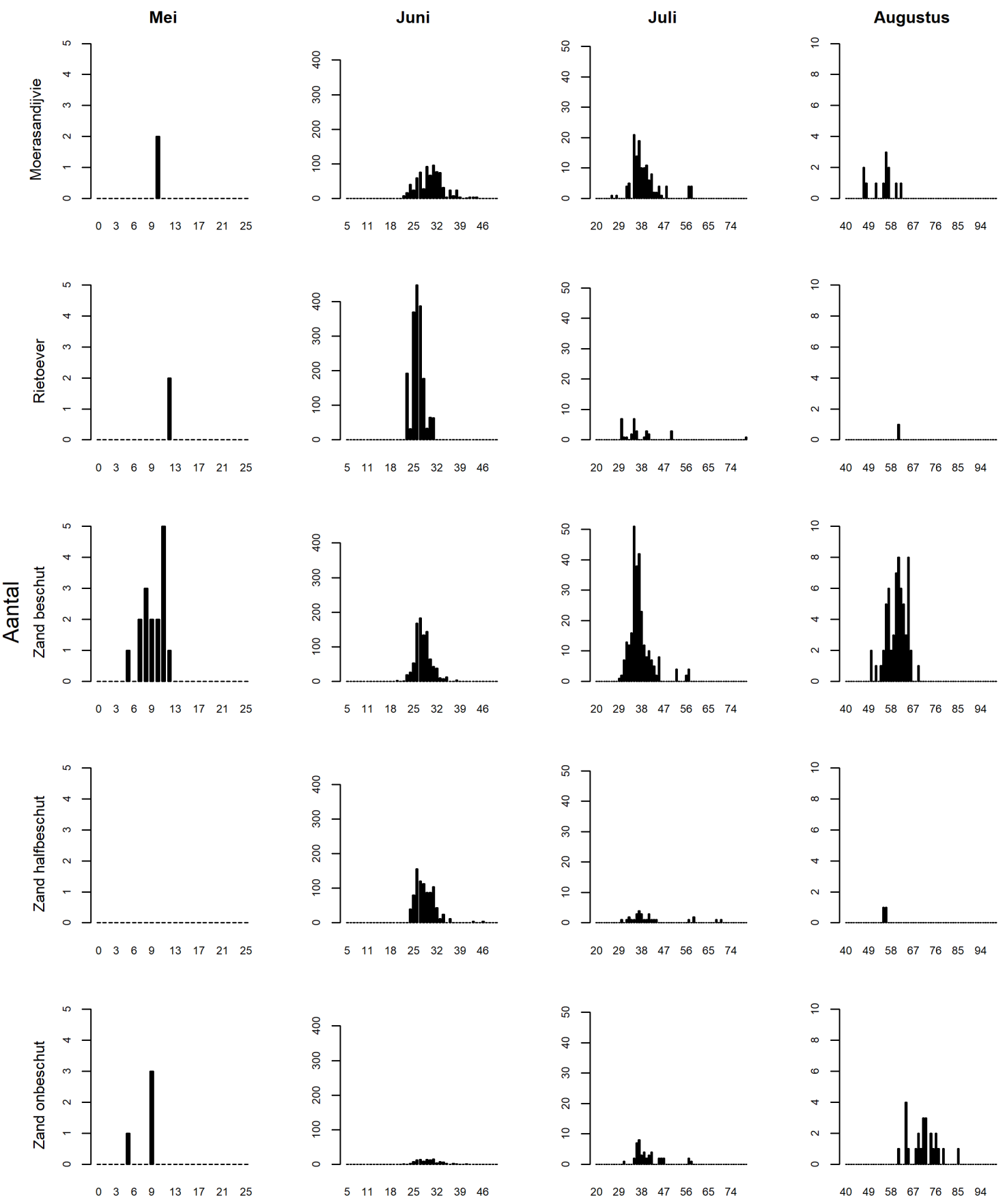

Lengte in $\mathrm{mm}$

Figuur B2.2. Lengte-frequentie (in $\mathrm{mm}$ ) grafieken van baars per maand en per bemonsterd habitat (moerasandijvie, rietoever en zandoever beschut, half-beschut en onbeschut) in 2020. 
Baars 2021
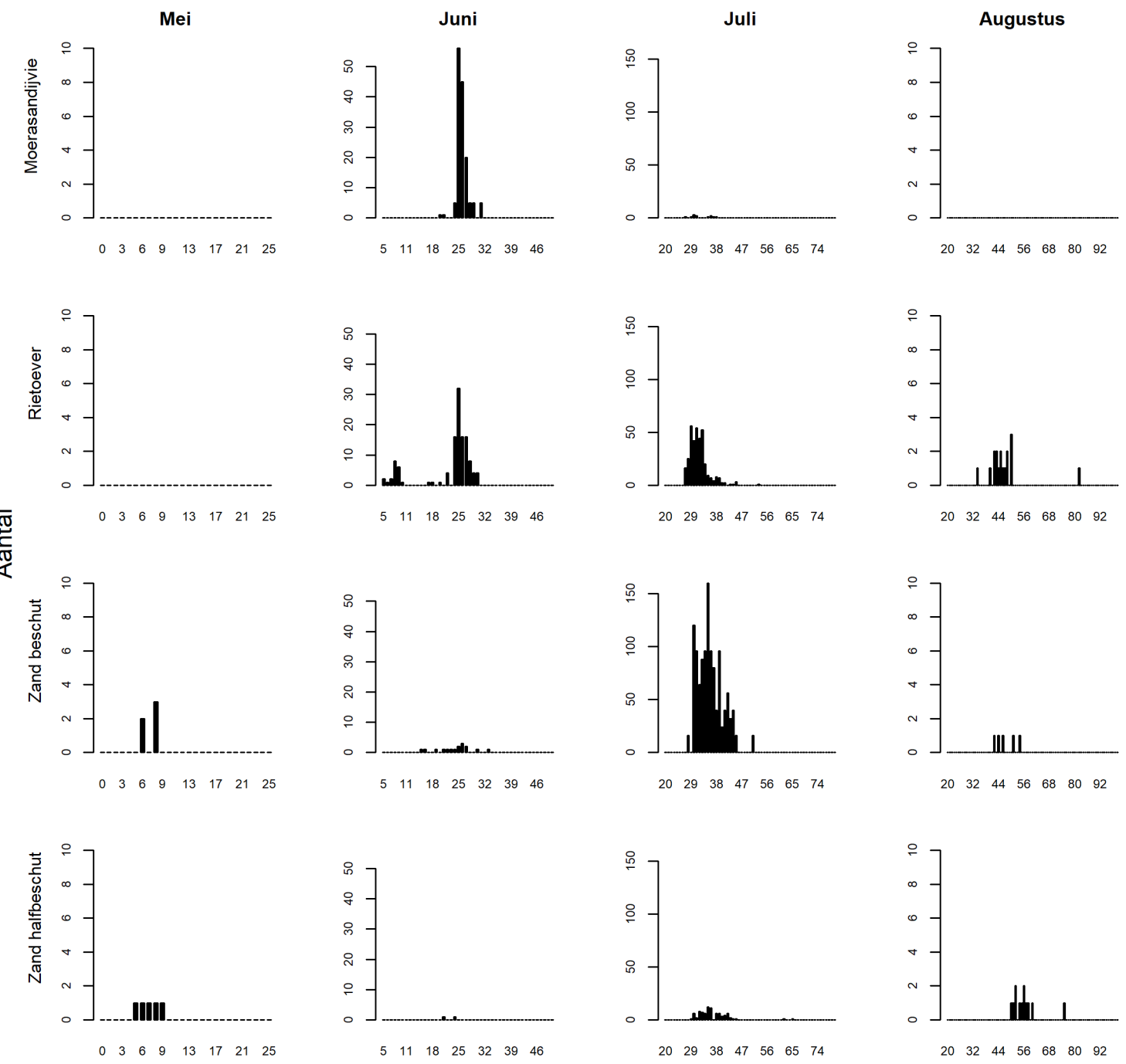

Lengte in $\mathrm{mm}$

Figuur B2.3. Lengte-frequentie (in $\mathrm{mm}$ ) grafieken van baars per maand en per bemonsterd habitat (moerasandijvie, rietoever en zandoever beschut en halfbeschut) in 2021. 


\section{B2.2 Blankvoorn}

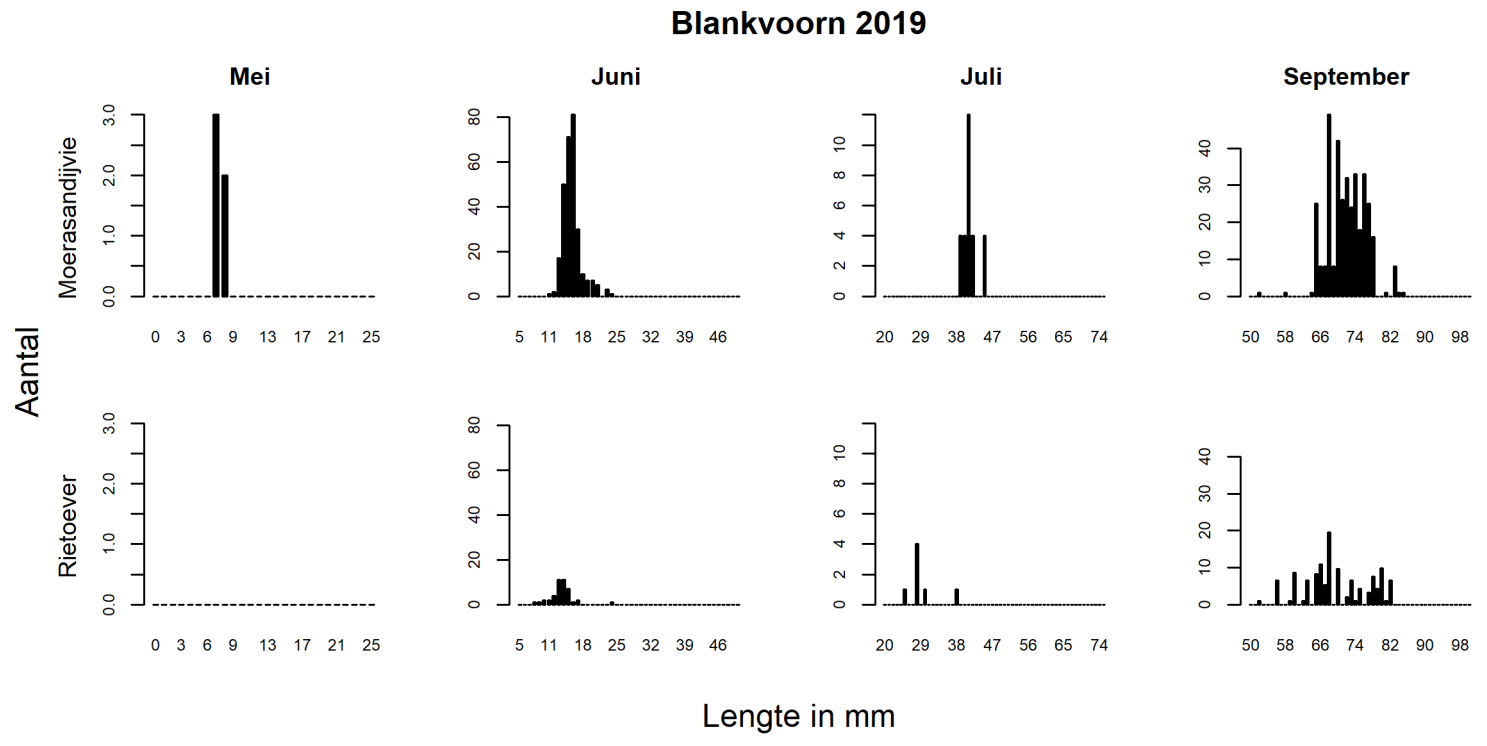

Figuur B2.4. Lengte-frequentie (in $\mathrm{mm}$ ) grafieken van blankvoorn per maand en per bemonsterd habitat (moerasandijvie en rietoever) in 2019 

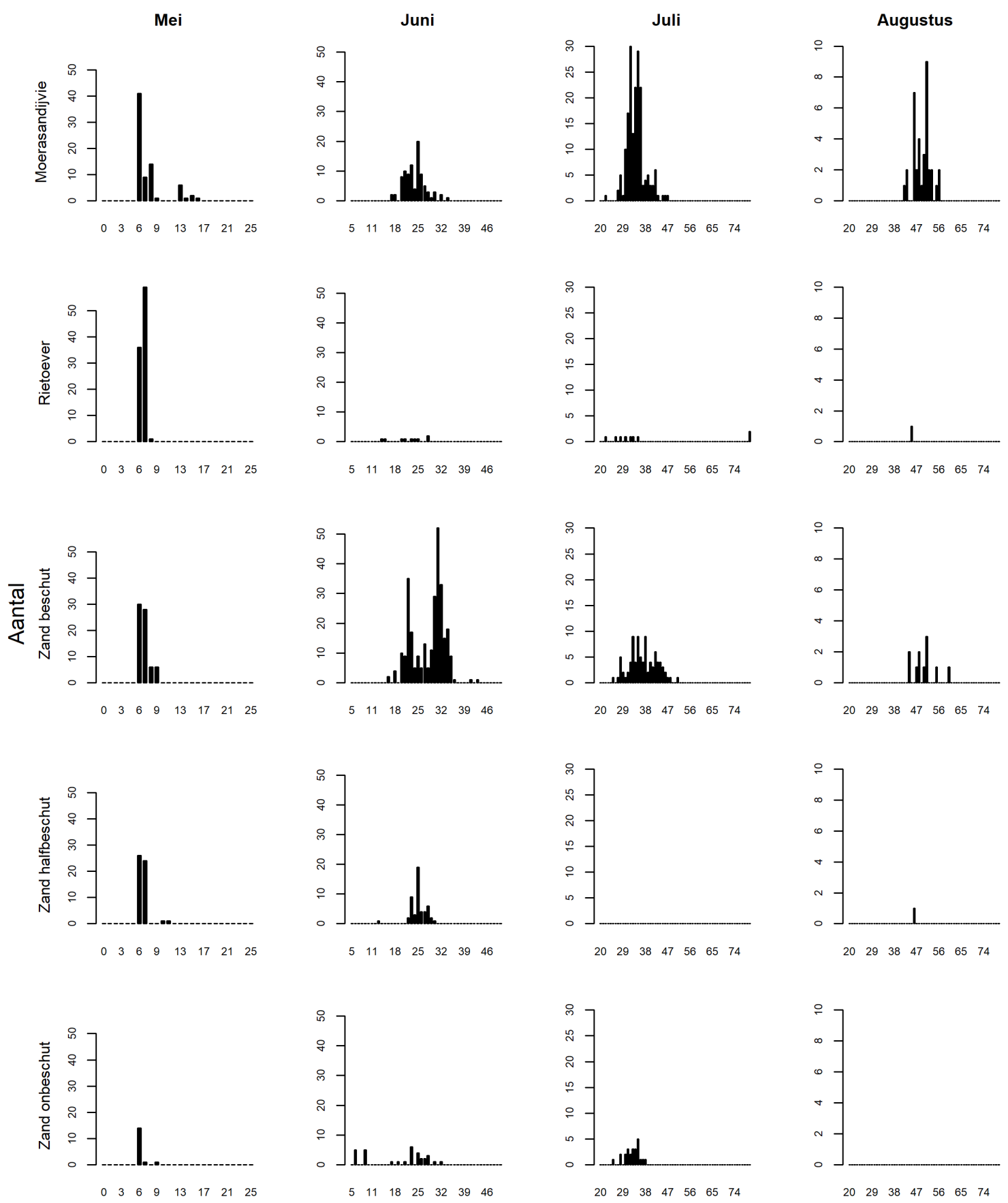

Lengte in $\mathrm{mm}$

Figuur B2.5. Lengte-frequentie (in $\mathrm{mm}$ ) grafieken van blankvoorn per maand en per bemonsterd habitat (moerasandijvie, rietoever en zandoever beschut, halfbeschut en onbeschut) in 2020.

In het habitat moerasandijvie in mei zijn op de locatie L35 en L36 de meeste blankvoorn met een lengte $<10 \mathrm{~mm}$ gevangen. De exemplaren $>10 \mathrm{~mm}$ zijn met name aangetroffen op de locatie L6. Voor het habitat zandoever half-beschut zijn veruit de meeste blankvoorn gevangen op de locaties $L 2$. De vangsten in het habitat zandoever onbeschut worden gedomineerd door de vangsten op locatie L32. In juni zijn voor het habitat zandoever onbeschut de kleinste blankvoorn (6 en $9 \mathrm{~mm}$ ) waargenomen op locatie L21. Tussen het moerasandijvie in juli zijn de meeste blankvoorn aangetroffen op locatie L36 en in minder mate op de locaties L6 en L9. In augustus zijn enkel nog blankvoorn gevangen tussen het moerasandijvie op locatie L6. 
Blankvoorn 2021
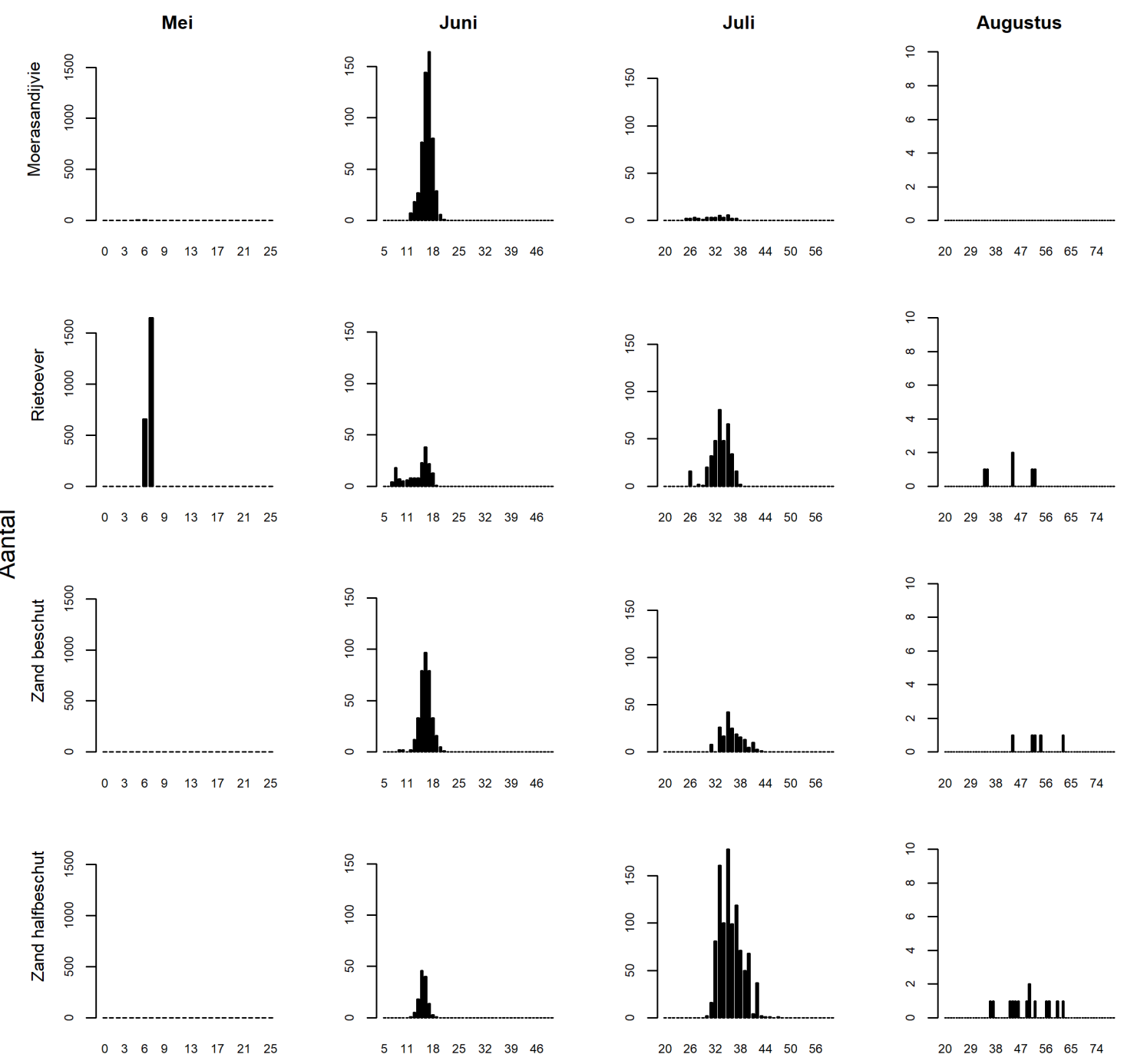

Lengte in $\mathrm{mm}$

Figuur B2.6. Lengte-frequentie (in $\mathrm{mm}$ ) grafieken van blankvoorn per maand en per bemonsterd habitat (moerasandijvie, rietoever en zandoever beschut en halfbeschut) in 2021. 
Driedoornige stekelbaars 2019
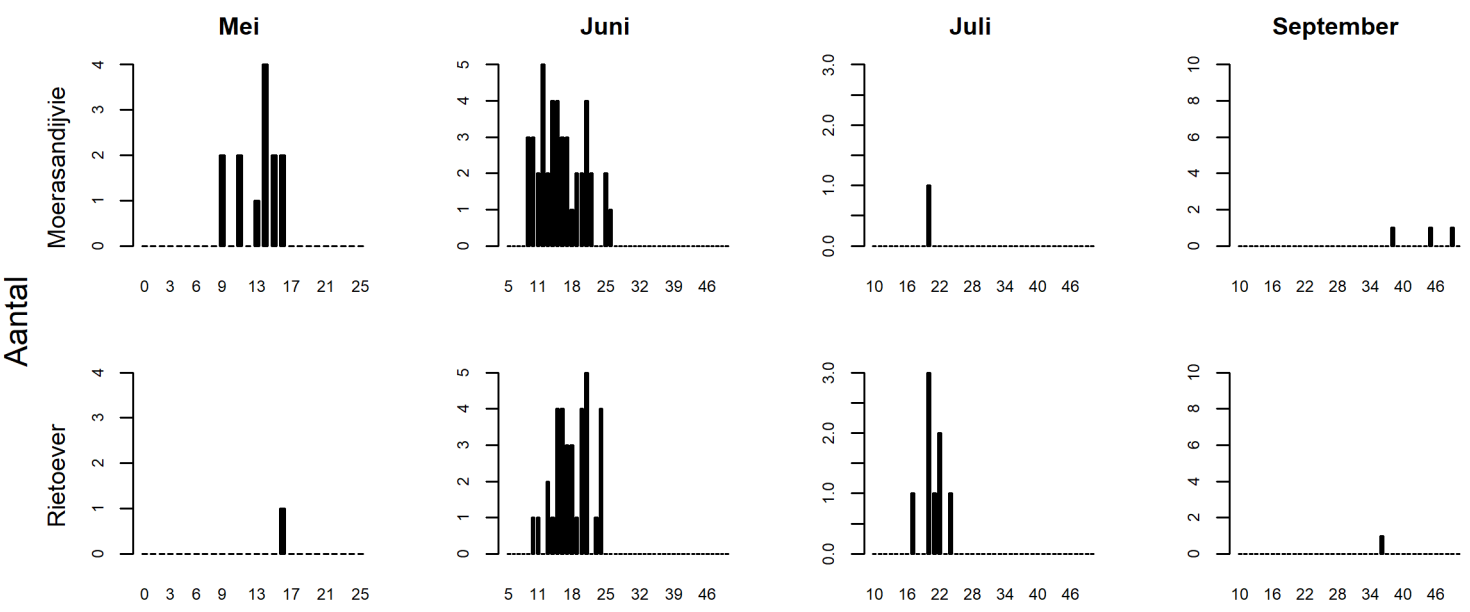

Lengte in $\mathrm{mm}$

Figuur B2.7. Lengte-frequentie (in $\mathrm{mm}$ ) grafieken van driedoornige stekelbaars per maand en per bemonsterd habitat (moerasandijvie en rietoever) in 2019. 


\section{Driedoornige stekelbaars 2020}
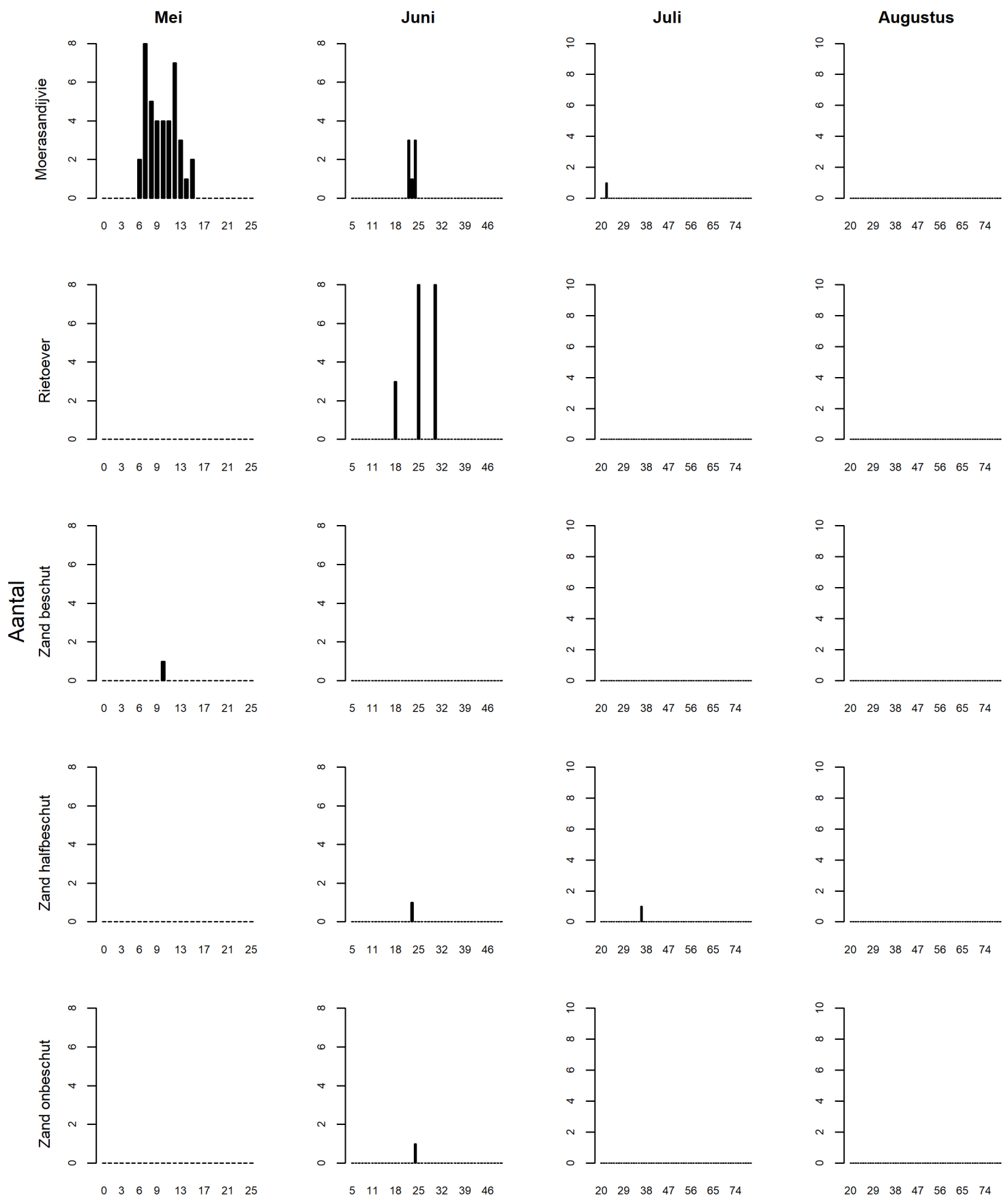

Lengte in $\mathrm{mm}$

Figuur B2.8. Lengte-frequentie (in $\mathrm{mm}$ ) grafieken van driedoornige stekelbaars per maand en per bemonsterd habitat (moerasandijvie, rietoever en zandoever beschut, halfbeschut en onbeschut) in 2020. 

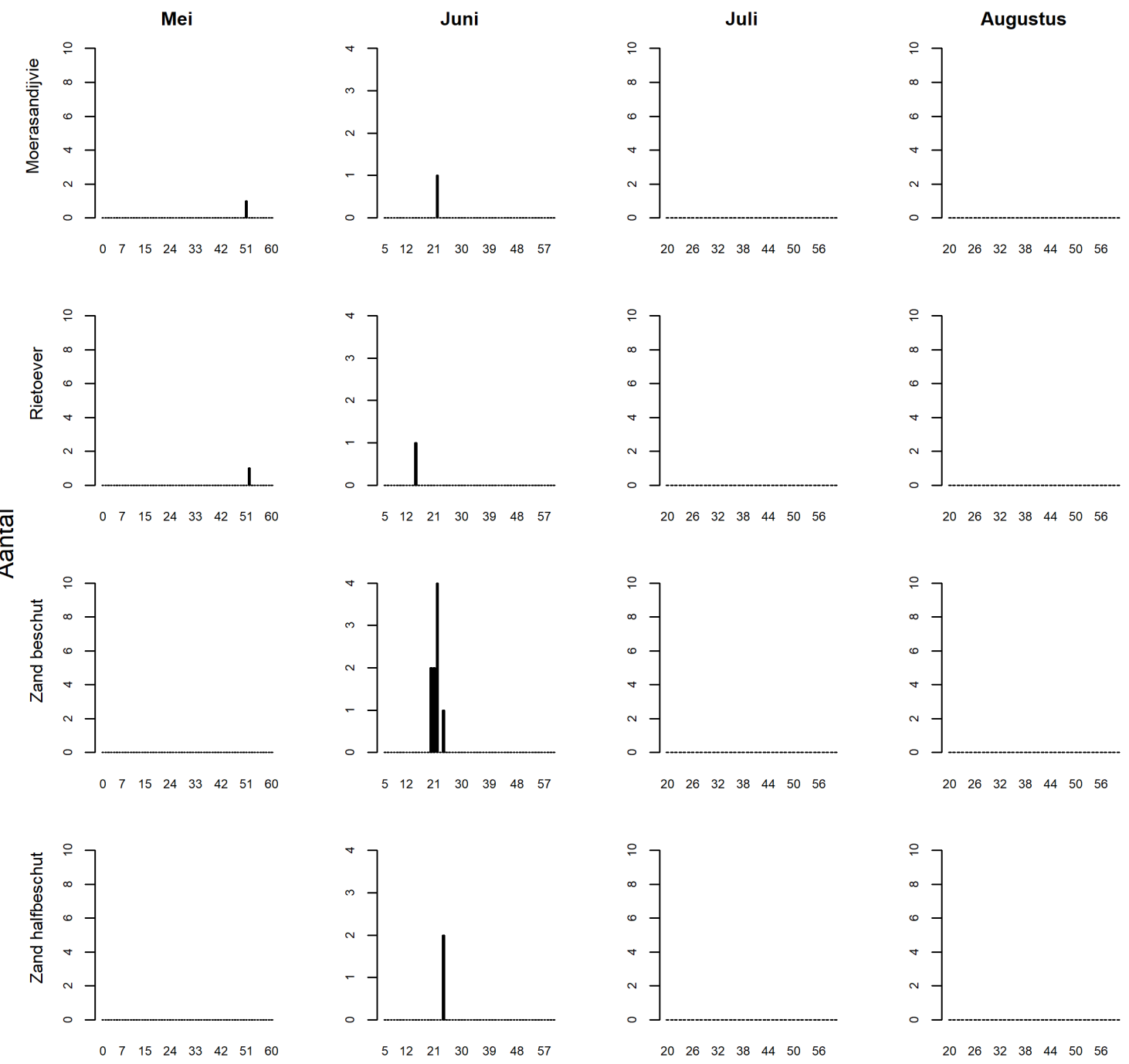

Lengte in $\mathrm{mm}$

Figuur B2.9. Lengte-frequentie (in $\mathrm{mm}$ ) grafieken van driedoornige stekelbaars per maand en per bemonsterd habitat (moerasandijvie, rietoever en zandoever beschut en halfbeschut) in 2021. 


\section{B2.4 Pos}

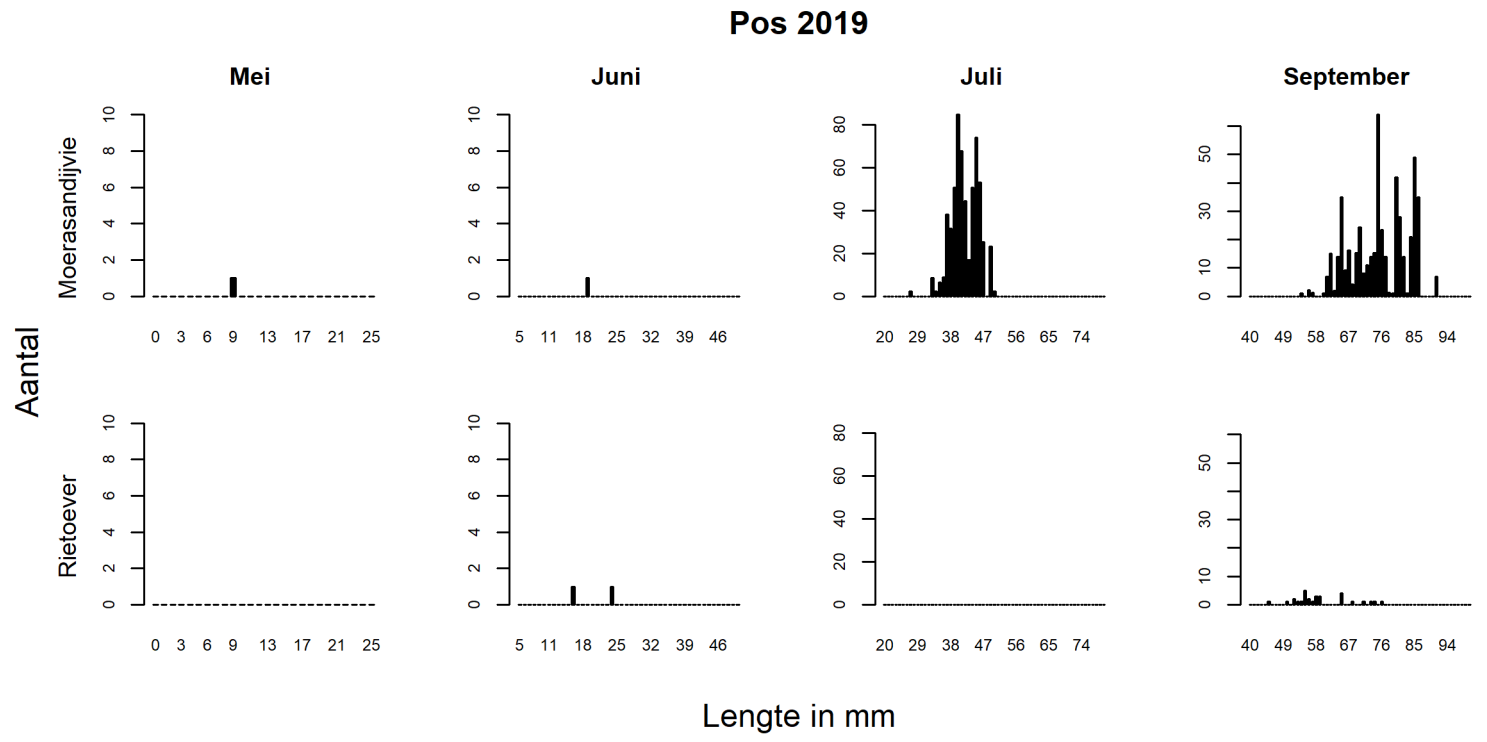

Figuur B2.10. Lengte-frequentie (in $\mathrm{mm}$ ) grafieken van pos per maand en per bemonsterd habitat (moerasandijvie en rietoever) in 2019. 
Pos 2020
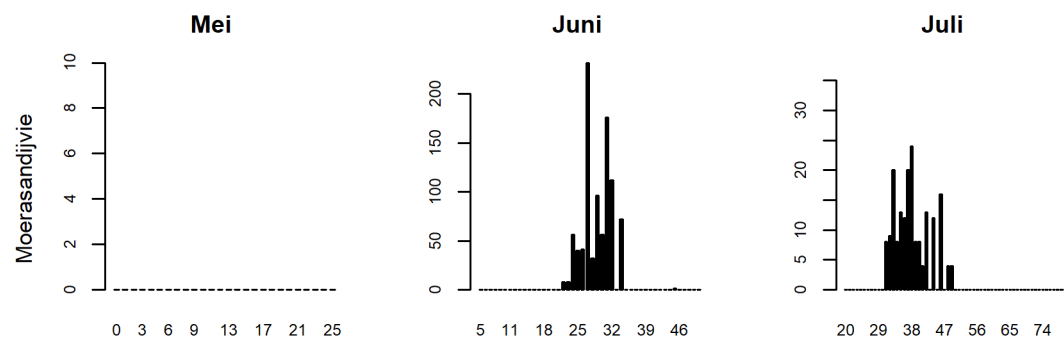

Augustus
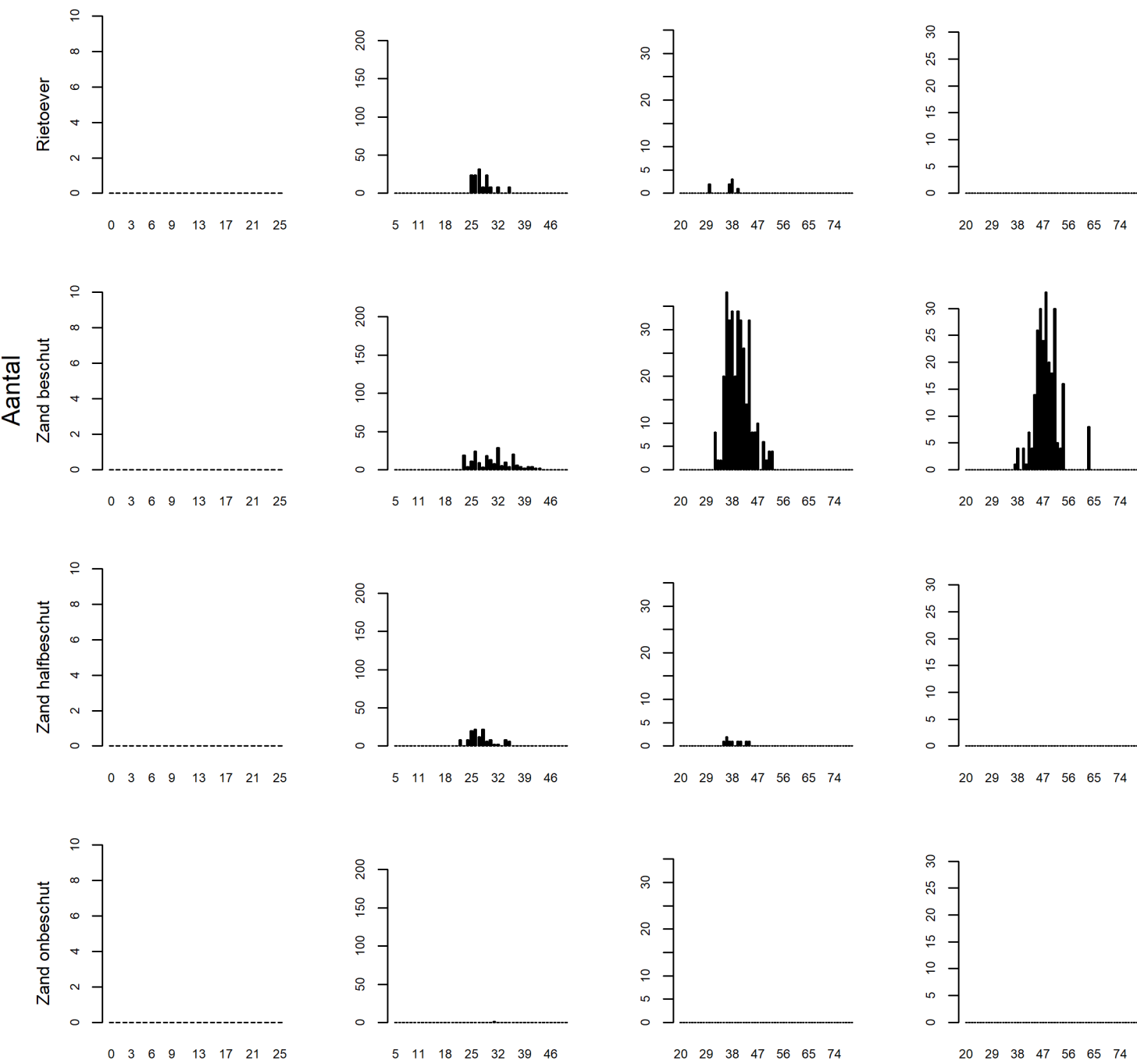

Lengte in $\mathrm{mm}$

Figuur B2.11. Lengte-frequentie (in $\mathrm{mm}$ ) grafieken van pos per maand en per bemonsterd habitat (moerasandijvie, rietoever en zandoever beschut, halfbeschut en onbeschut) in 2020. 


\section{Pos 2021}
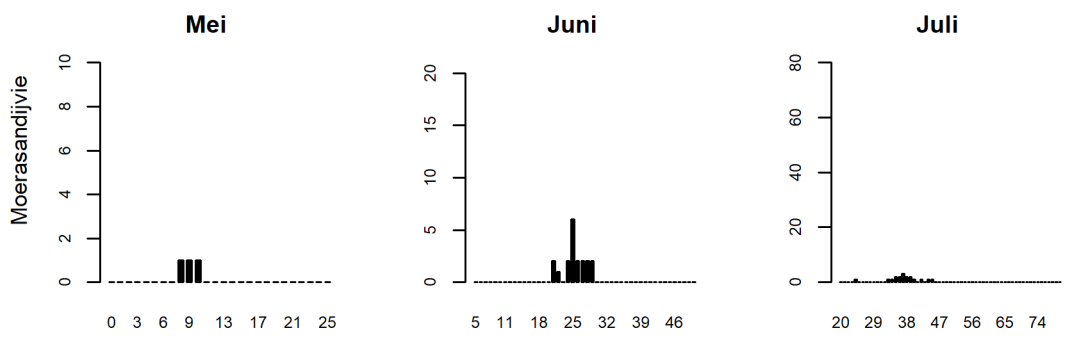

Augustus
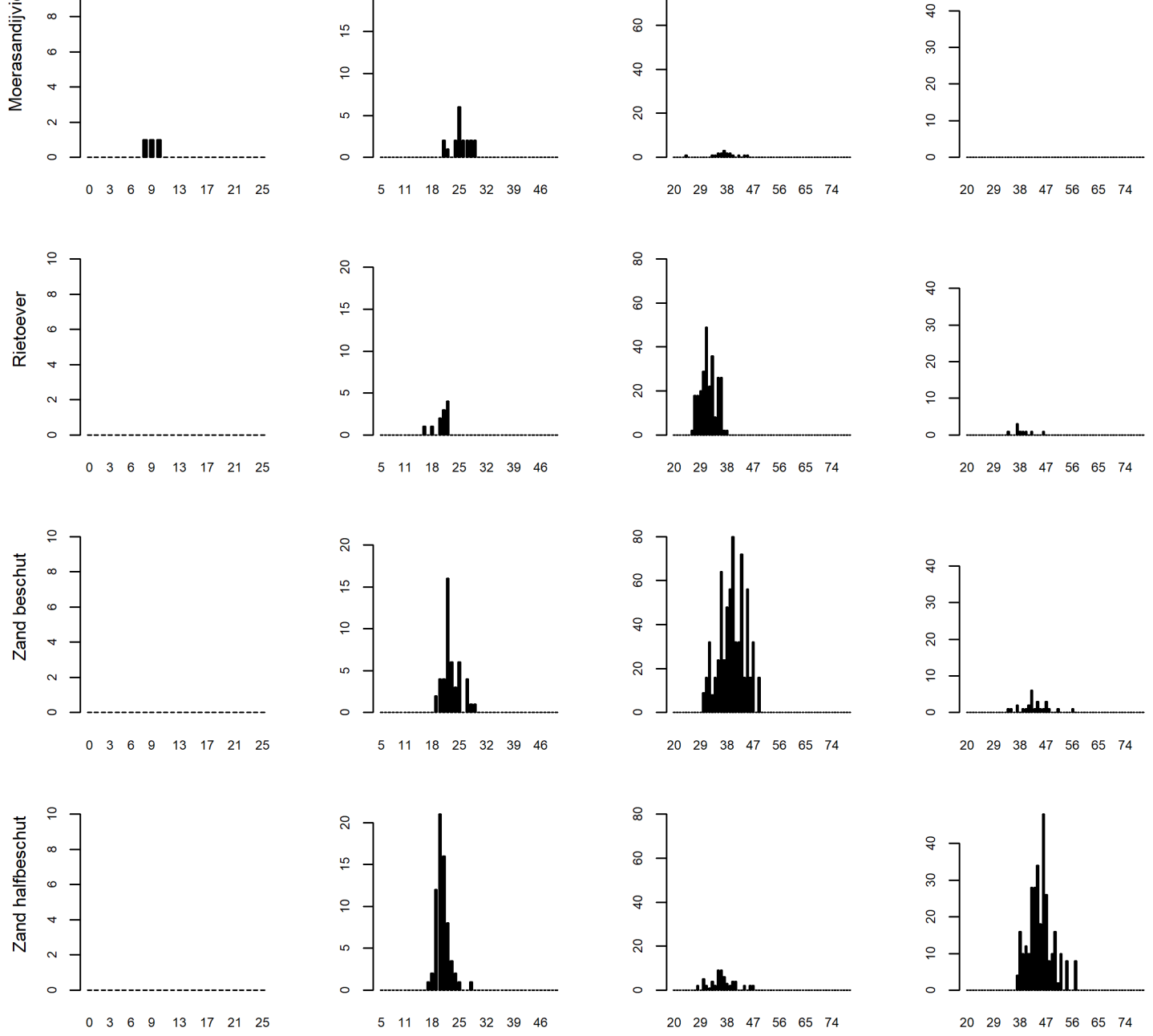

Lengte in $\mathrm{mm}$

Figuur B2.12. Lengte-frequentie (in $\mathrm{mm}$ ) grafieken van pos per maand en per bemonsterd habitat (moerasandijvie, rietoever en zandoever beschut en halfbeschut) in 2021. 


\section{B2.5 Snoekbaars}

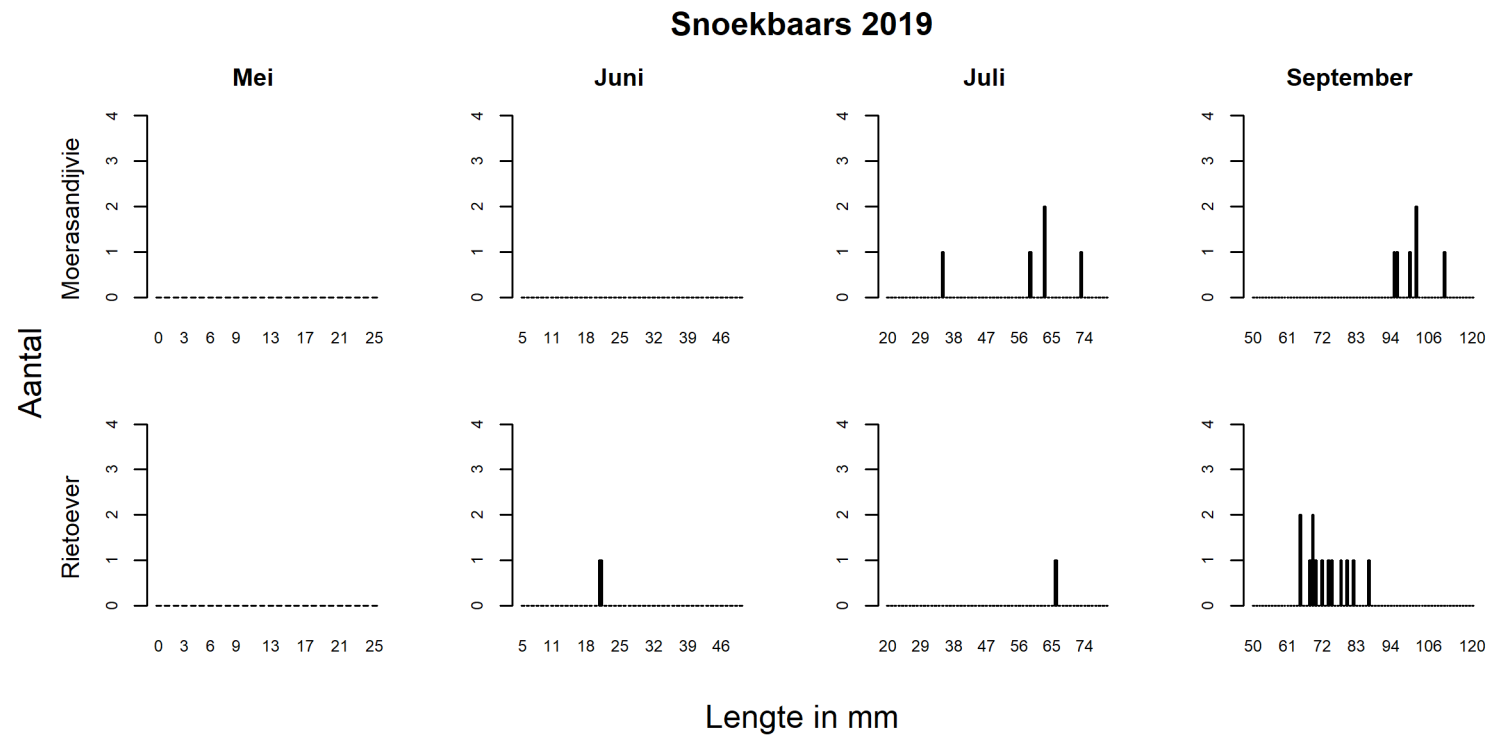

Figuur B2.13. Lengte-frequentie (in $\mathrm{mm}$ ) grafieken van snoekbaars per maand en per bemonsterd habitat (moerasandijvie en rietoever) in 2019. 
Snoekbaars 2020
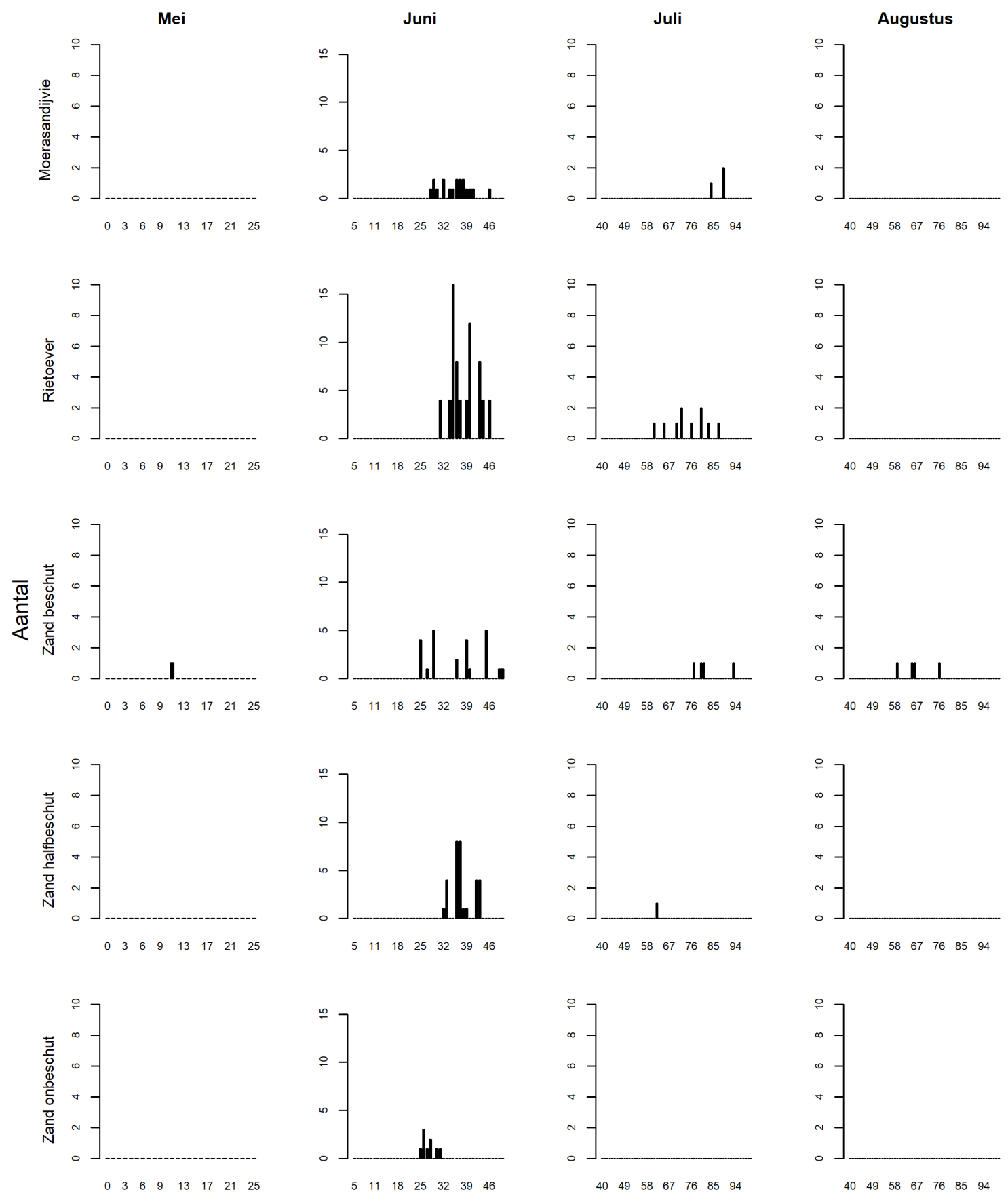

Lengte in $\mathrm{mm}$

Figuur B2.14. Lengte-frequentie (in $\mathrm{mm}$ ) grafieken van snoekbaars per maand en per bemonsterd habitat (moerasandijvie, rietoever en zandoever beschut, halfbeschut en onbeschut) in 2020. 
Snoekbaars 2021
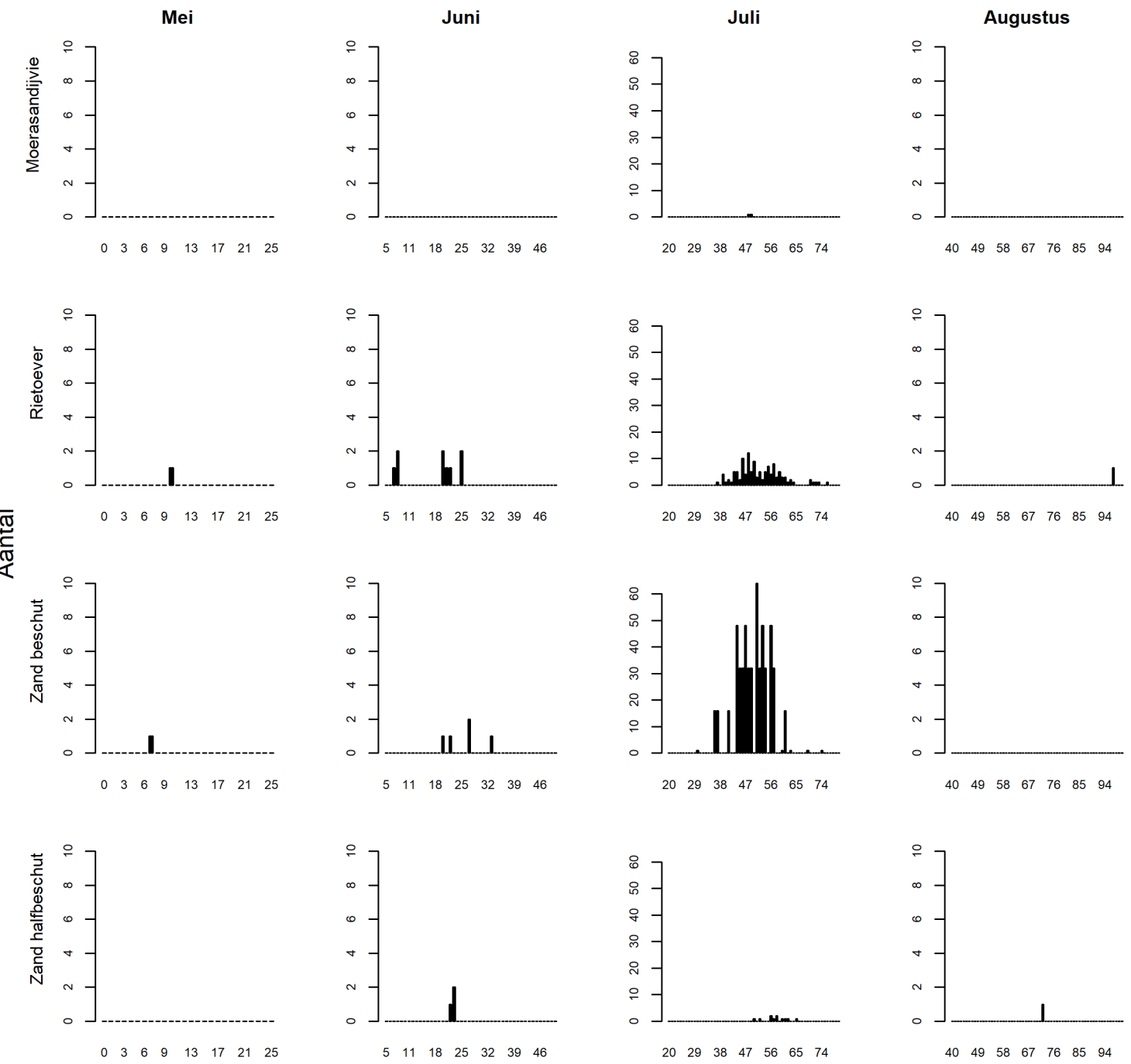

\section{Lengte in $\mathrm{mm}$}

Figuur B2.15. Lengte-frequentie (in $\mathrm{mm}$ ) grafieken van snoekbaars per maand en per bemonsterd habitat (moerasandijvie, rietoever en zandoever beschut en halfbeschut) in 2021. 


\section{B2.6 Winde}

In de lengte verdeling van juli voor het moerasandijvie habitat is een duidelijke tweedeling te zien (bimodale verdeling), waarbij de split rond de $42 \mathrm{~mm}$ zit. In totaal zijn vier verschillende locaties (L10, L7, L6, L6geul) bemonsterd die vallen onder het habitat moerasandijvie waarbij enkel met de zegen is bemonsterd. Op locatie L6 zijn uitsluitend winde gevangen van de eerste cohort ( $<43 \mathrm{~mm}$ ), op locatie L10 zijn juist uitsluitend winde van > $45 \mathrm{~mm}$ gevangen. In de geul bij locatie L6 (L6geul) zijn zowel winde van de eerste als de tweede cohort gevangen.

\section{Winde 2019}
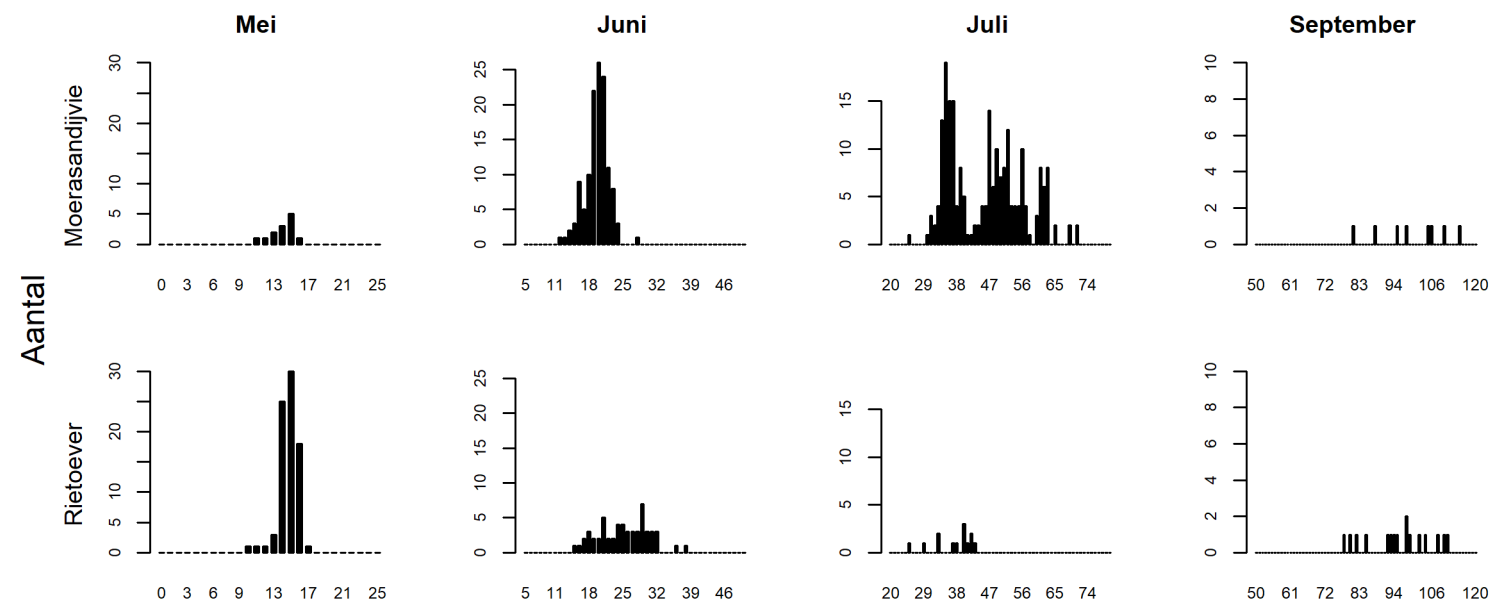

Lengte in $\mathrm{mm}$

Figuur B2.16. Lengte-frequentie (in $\mathrm{mm}$ ) grafieken van winde per maand en per bemonsterd habitat (moerasandijvie en rietoever) in 2019.

In 2020 zijn er maar een zeer beperkt aantal winde gevangen. In juni zijn 6 winde variërend in lengte van 13 tot $18 \mathrm{~mm}$ aangetroffen in moerasandijvie die potentieel tot ontwikkeling zijn gekomen in het voorjaar van 2020 op de Marker Wadden. De overige winde waren groter dan 50 mm waarbij de aantallen gering waren. Ook in 2021 is mar een beperkt aantal winde gevangen. 


\section{Bijlage 3 Groei}

Bijlage 3 - Gemiddelde groei per bemonsteringslocatie

\section{Blankvoorn 2019}

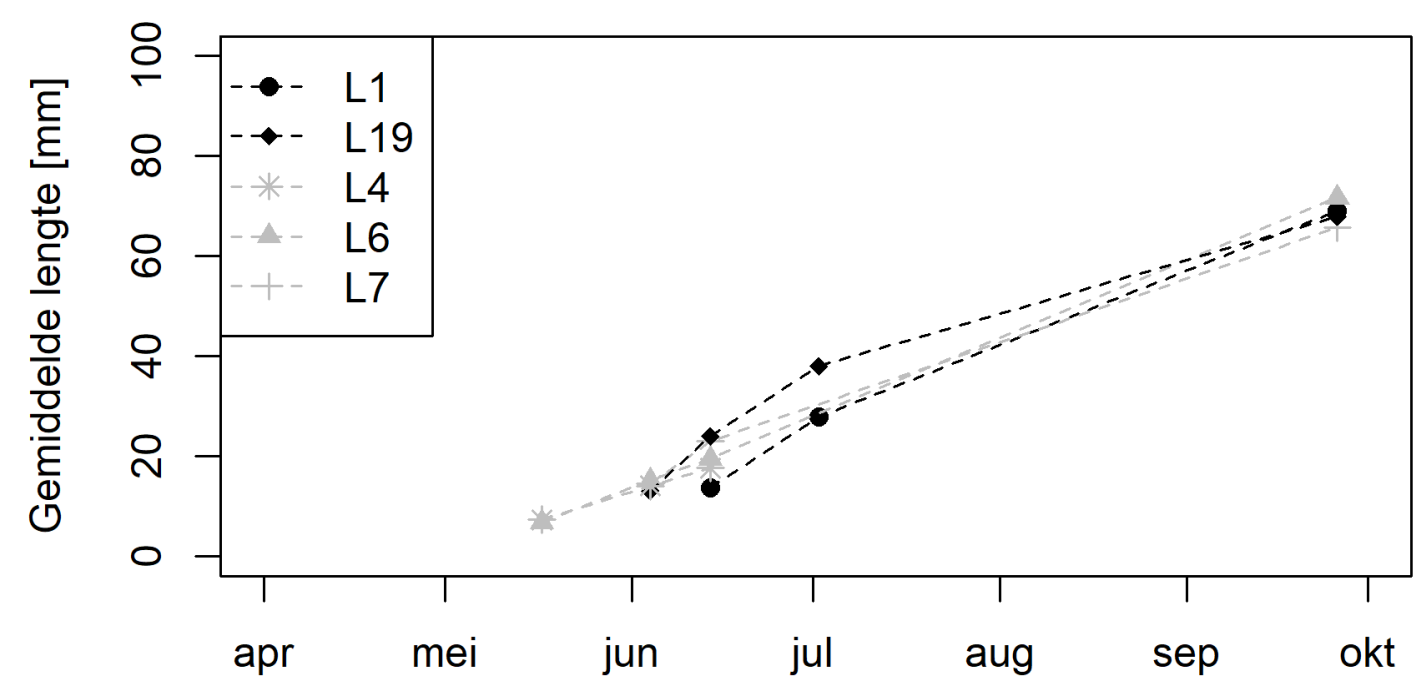

Figuur B3.1. Gemiddelde lengte van blankvoorn in $\mathrm{mm}$ per bemonsteringslocatie in 2019. Locatie L1 en L19 representeren rietoevers (zwart) en de locaties L4, L6 en L7 moerasandijvie (grijs).

\section{Winde 2019}

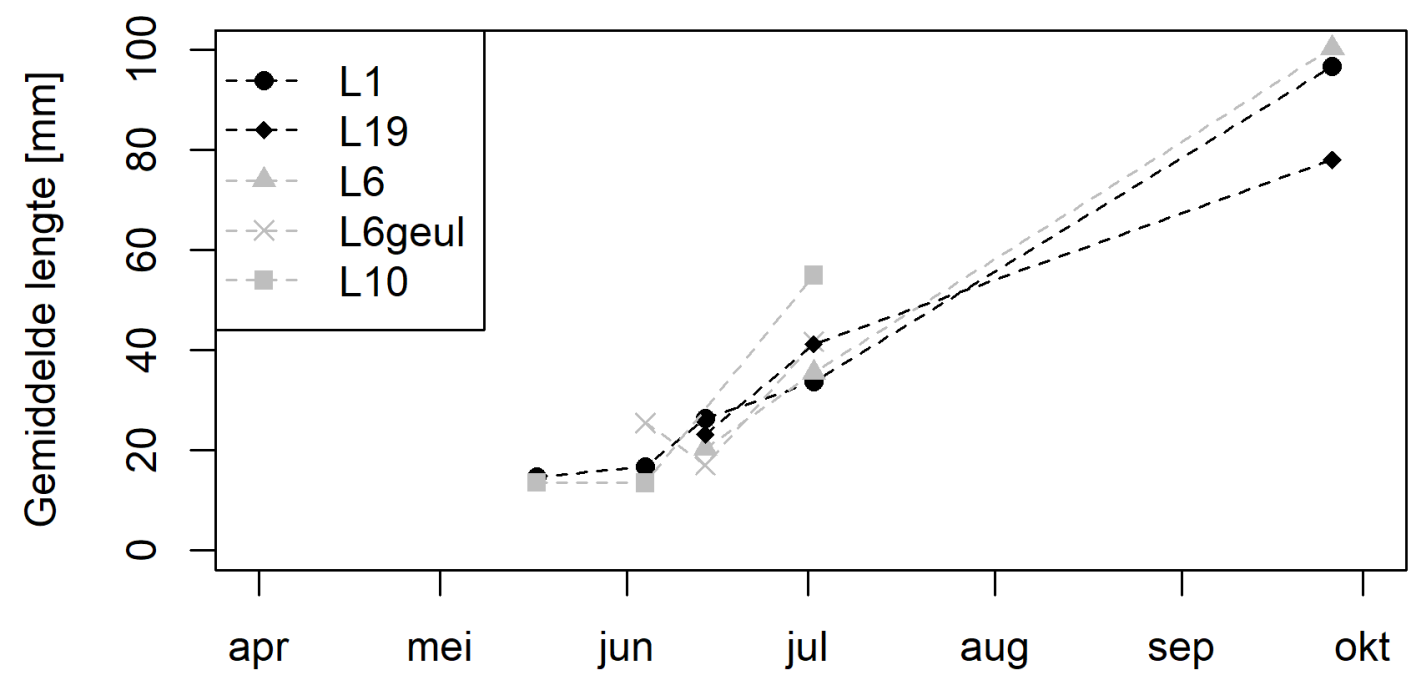

Figuur B3.2. Gemiddelde lengte van winde in $\mathrm{mm}$ per bemonsteringslocatie in 2019. Locatie L1 en L19 representeren rietoevers (zwart) en de locaties L4, L6 en L7 moerasandijvie (grijs). 


\section{Baars 2020}

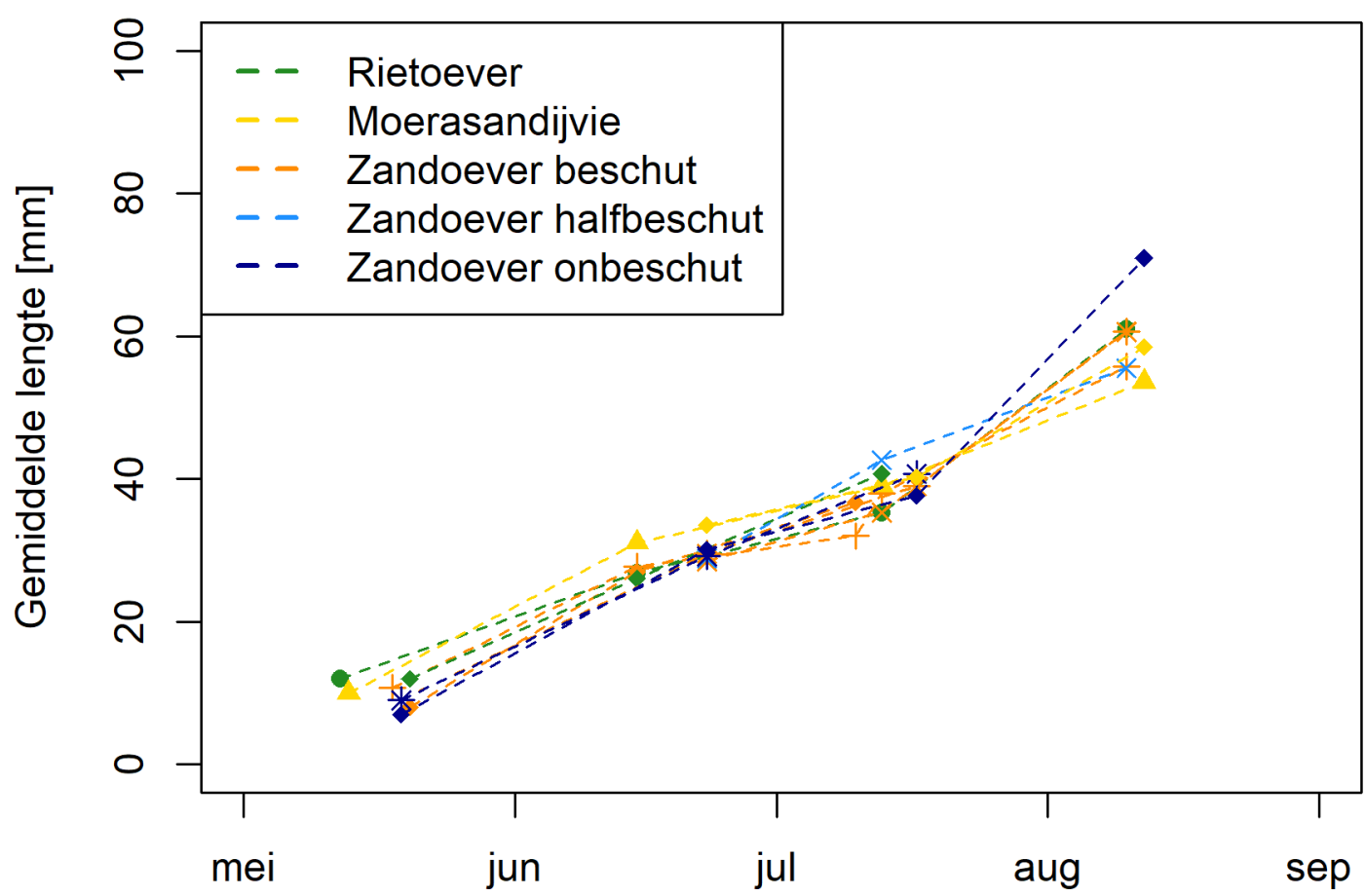

Figuur B3.3. Gemiddelde lengte van baars in $\mathrm{mm}$ per bemonsteringslocatie in 2020. Rietoevers $\mathrm{L} 1$ en L19 (groen), Moerasandijvie L6 en L35 (geel), beschutte zandoevers L2, L5, L13 en L31 (oranje), halfbeschutte zandoever L20, L30 en L32 (lichtblauw) en onbeschutte zandoevers L21, L33 en L34 (paars).

\section{Blankvoorn 2020}

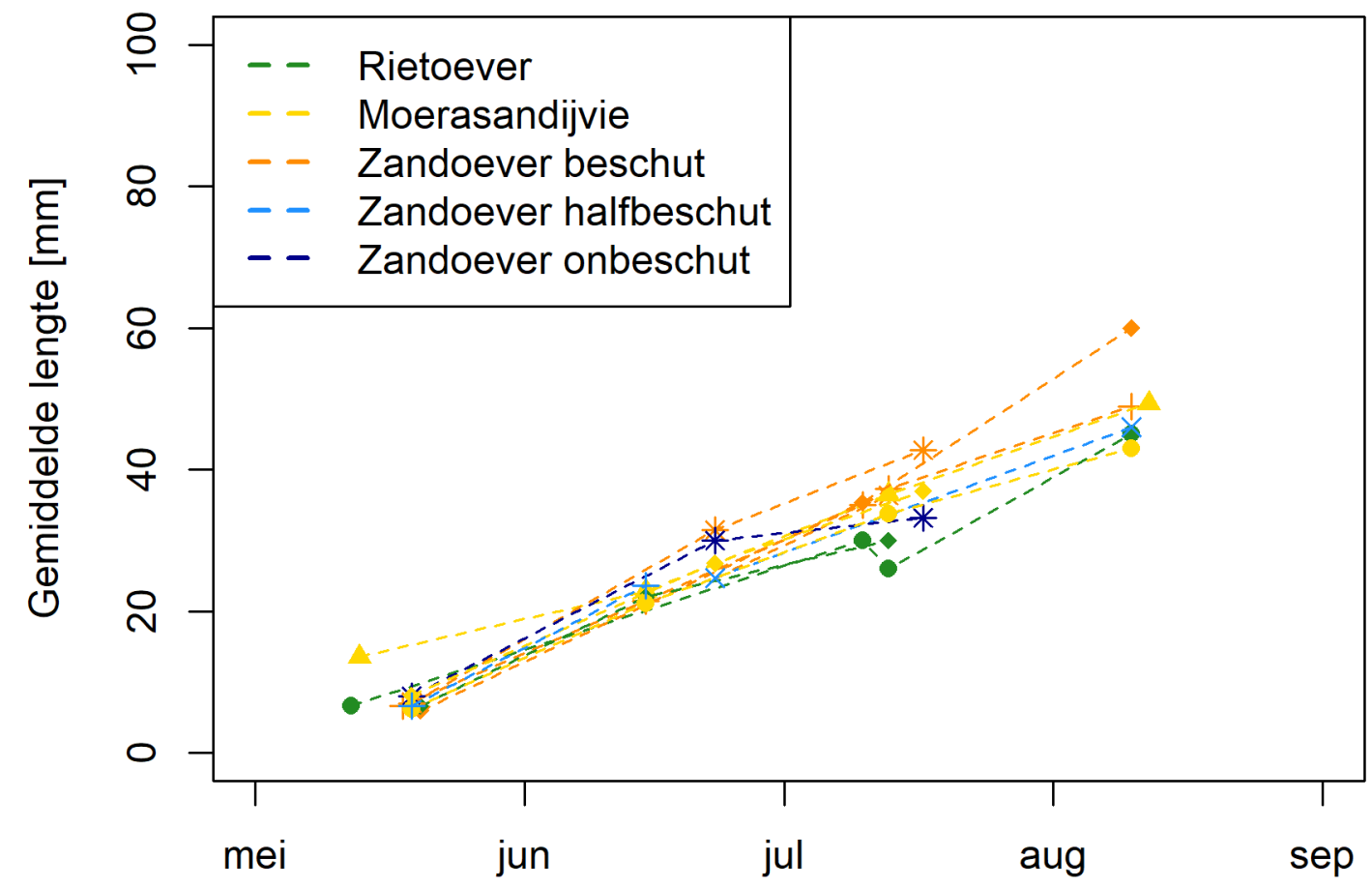

Figuur B3.4. Gemiddelde lengte van blankvoorn in $\mathrm{mm}$ per bemonsteringslocatie in 2020. Rietoevers L1 en L19 (groen), Moerasandijvie L6 en L35 (geel), beschutte zandoevers L2, L5, L13 en L31 (oranje), halfbeschutte zandoevers L20, L30 en L32 (lichtblauw) en onbeschutte zandoevers L21, L33 en L34 (paars). 


\section{Baars 2021}

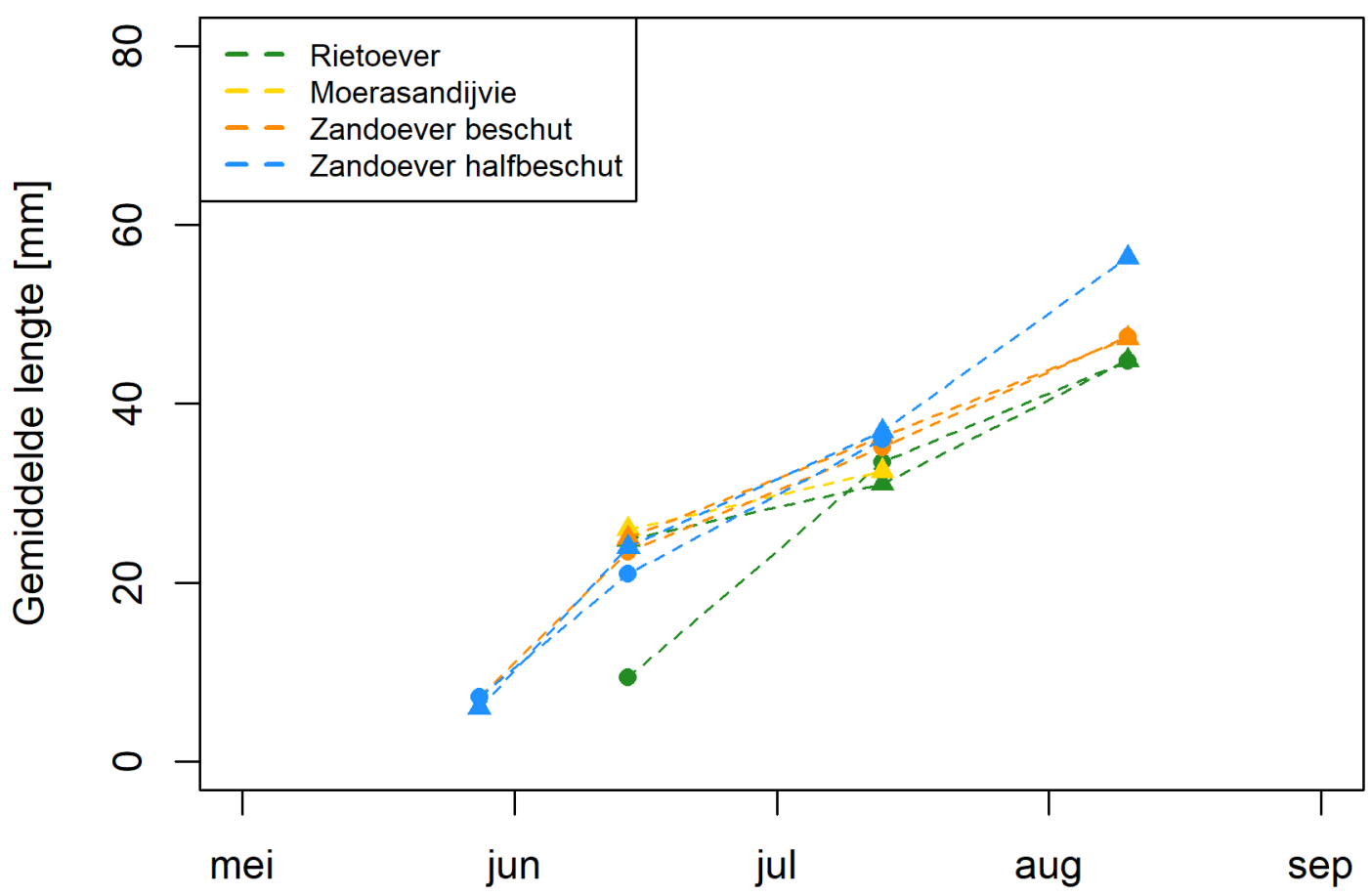

Figuur B3.5. Gemiddelde lengte van baars in $\mathrm{mm}$ per bemonsteringslocatie in 2021 . Rietoevers L1 en L19 (groen), Moerasandijvie L6 en L35 (geel), beschutte zandoevers L4 en L13 (oranje), halfbeschutte zandoevers L20 en L30 (lichtblauw).

\section{Blankvoorn 2021}

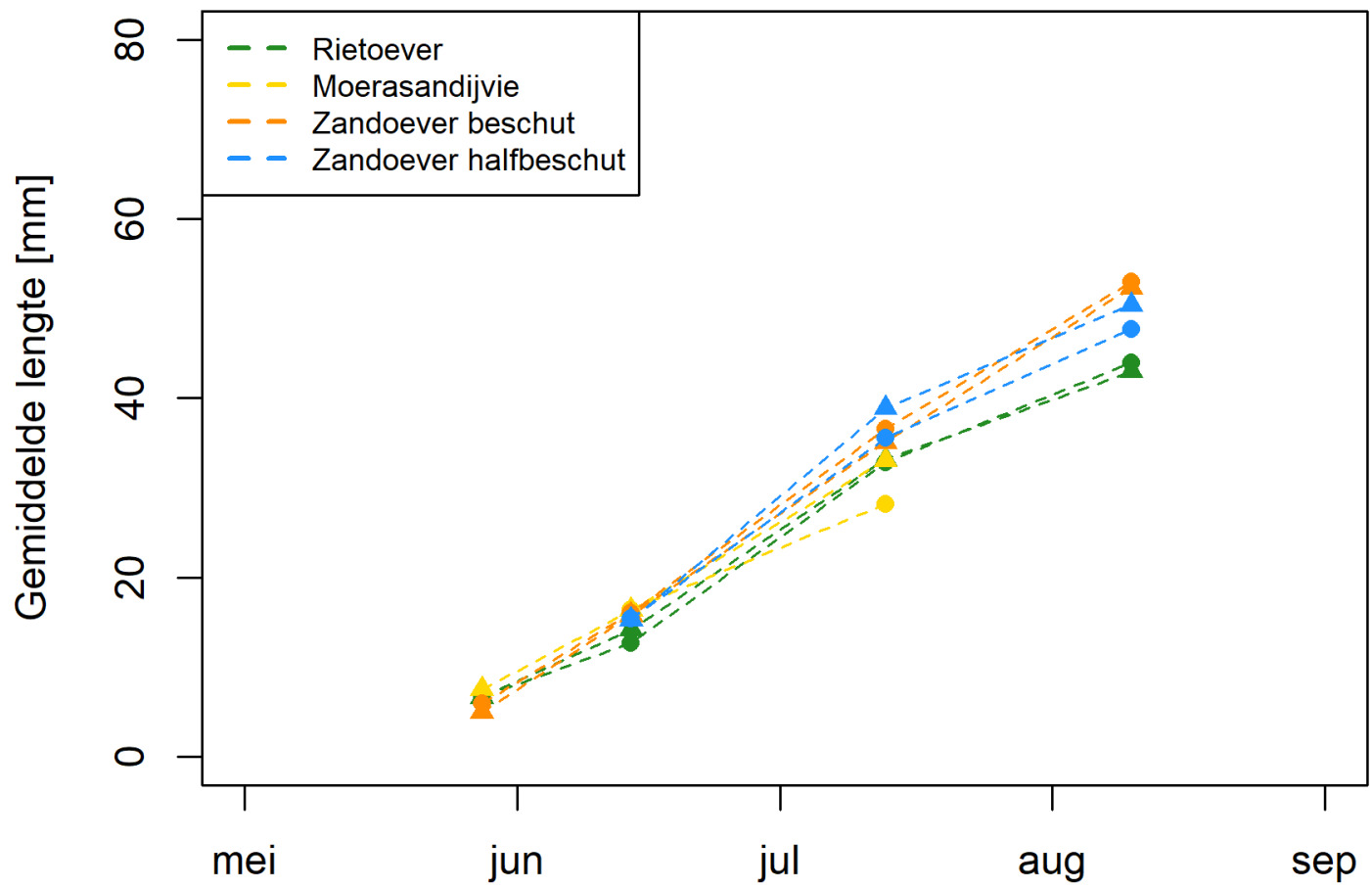

Figuur B3.6. Gemiddelde lengte van blankvoorn in $\mathrm{mm}$ per bemonsteringslocatie in 2021 . Rietoevers L1 en L19 (groen), Moerasandijvie L6 en L35 (geel), beschutte zandoevers L4 en L13 (oranje), halfbeschutte zandoevers L20 en L30 (lichtblauw). 


\section{Pos 2021}

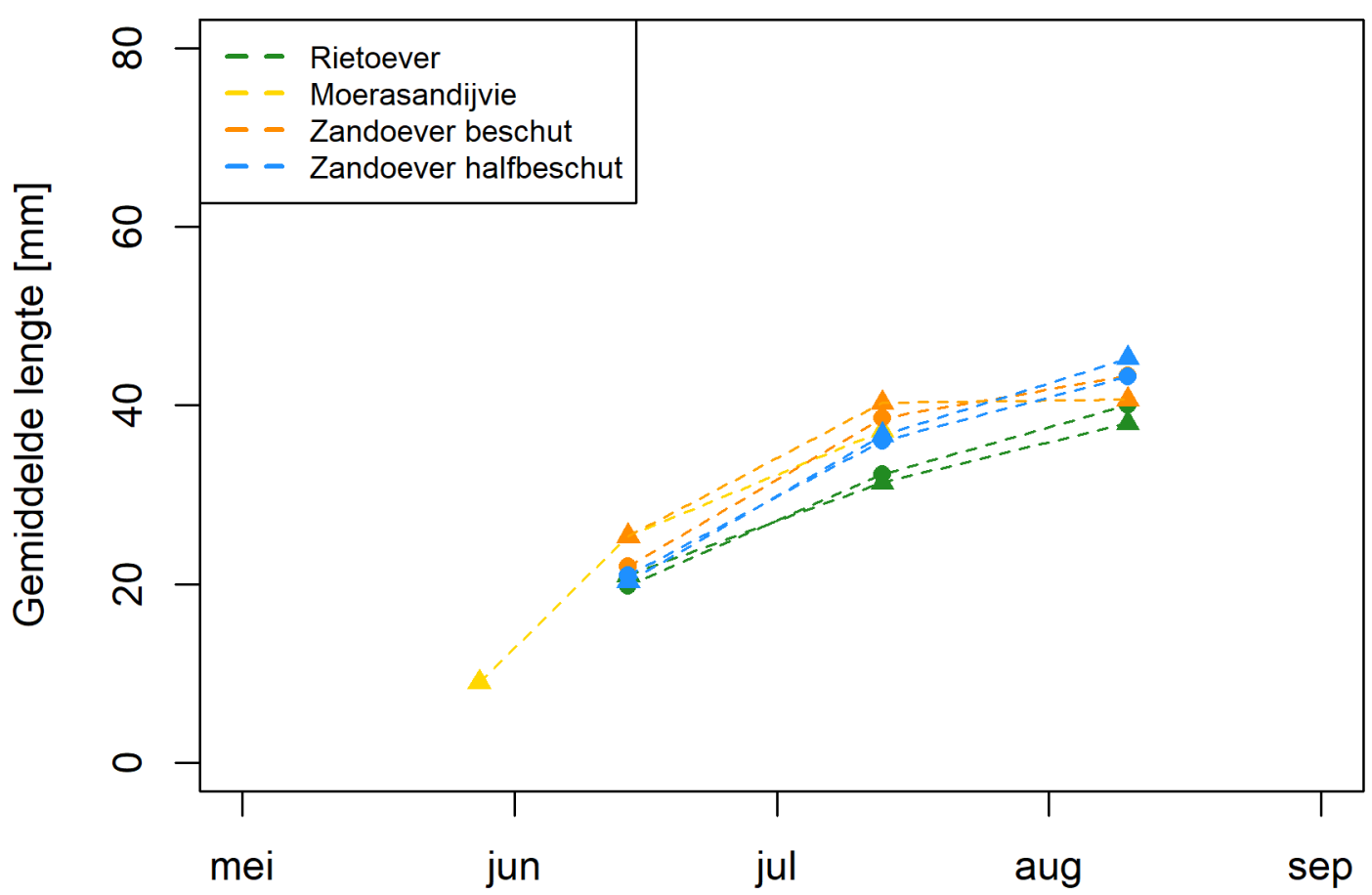

Figuur B3.7. Gemiddelde lengte van pos in $\mathrm{mm}$ per bemonsteringslocatie in 2021. Rietoevers L1 en L19 (groen), Moerasandijvie L6 en L35 (geel), beschutte zandoevers L4 en L13 (oranje), halfbeschutte zandoevers L20 en L30 (lichtblauw).

\section{Snoekbaars 2021}

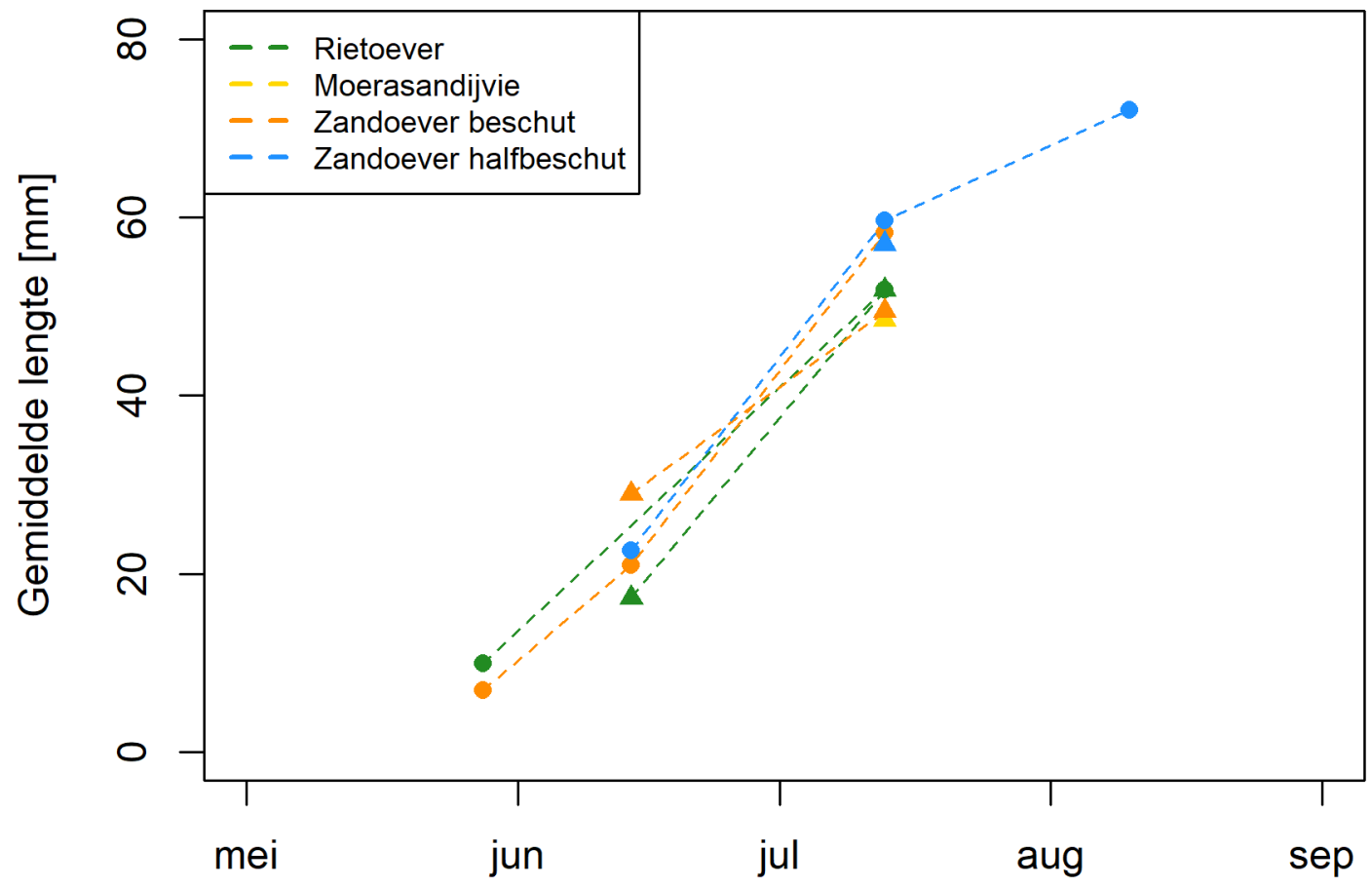

Figuur B3.8. Gemiddelde lengte van snoekbaars in $\mathrm{mm}$ per bemonsteringslocatie in 2021. Rietoevers L1 en L19 (groen), Moerasandijvie L6 en L35 (geel), beschutte zandoevers L4 en L13 (oranje), halfbeschutte zandoevers L20 en L30 (lichtblauw). 


\section{Bijlage 4 Windrozen}

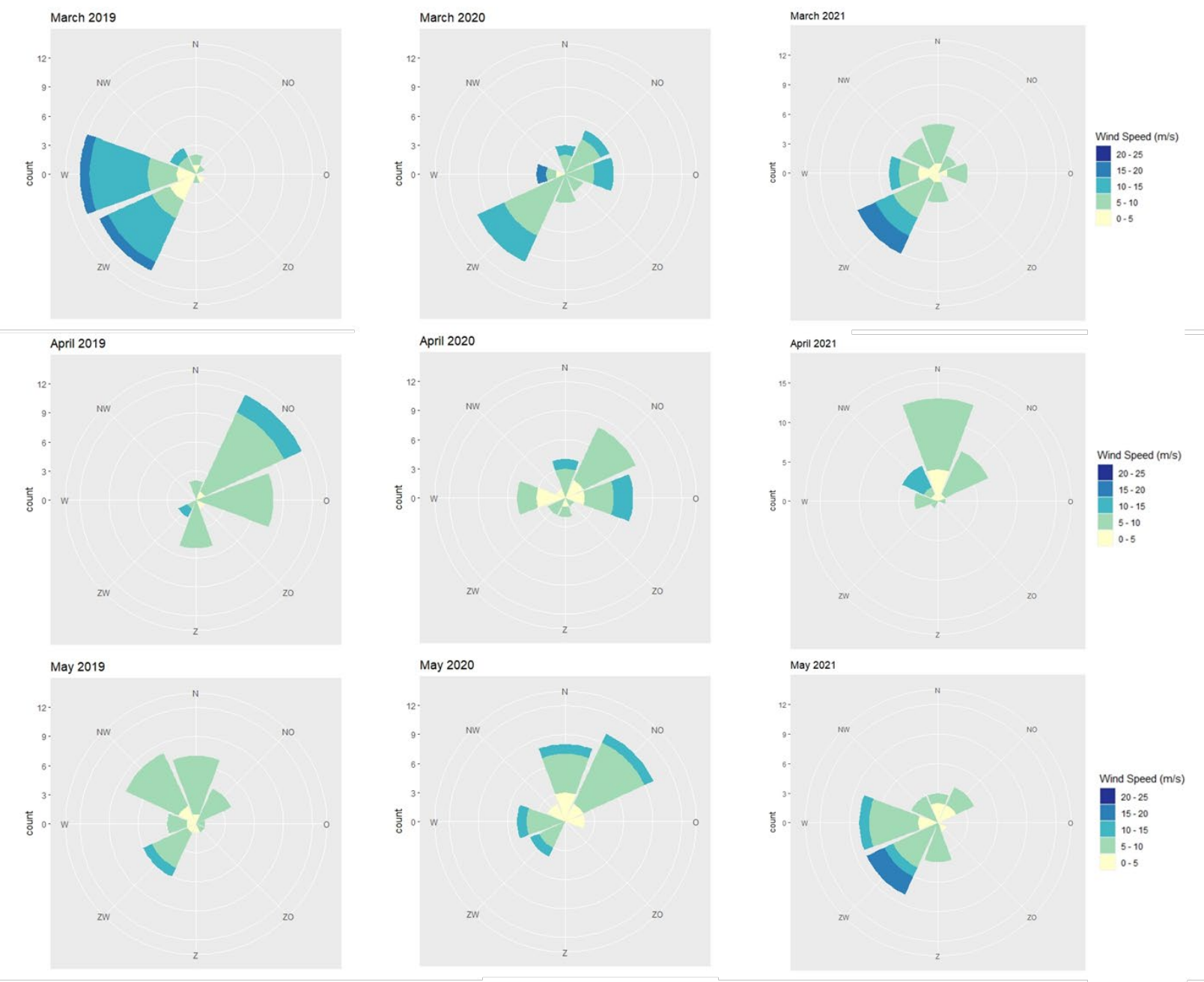

Figuur B4.1. Dominante windrichting en gemiddelde windsnelheid in $[\mathrm{m} / \mathrm{s}]$ over een etmaal voor 2019 (links), 2020 (midden) en 2021 (rechts) voor de maanden maart, april en mei van meetpaal Houtribdijk. De kleuren tonen de gemiddelde windsnelheid over een etmaal en de grootte van elk segment (taartpunt) geeft het aantal dagen per maand van de desbetreffende windrichting weer. 


\section{Bijlage 5 Trintelzand}

\section{Vangsten van jonge vis op enkele locaties op Trintelzand, 16 juni 2020.}

Op 16 juni 2020 zijn enkele bemonsteringen van jonge vis uitgevoerd op het Trintelzand om een vergelijking te maken met bemonsteringen van paai- en opgroeihabitats zoals die zich ontwikkelen op Marker Wadden. De bemonsteringen werden uitgevoerd met een $15 \mathrm{~m}$ broedzegen en aangevuld met bemonsteringen met een RAVON-net op interessante locaties wanneer bemonsteren met de broedzegen niet mogelijk was.

\author{
locatie \\ T1 lon 5.37100, lat 52.65050 \\ T2 Ion 5.37433 , lat 52.63967 \\ T3 Ion 5.38517, lat 52.63717 \\ T4 Ion 5.38633, lat 52.63867 \\ T5 Ion 5.38550 , lat 52.63883
}

\section{omschrijving}

monding binnendelta NW monding binnendelta ZW monding binnendelta $Z$ monding binnendelta $Z$ geul monding binnendelta $Z$ kleine geul RAVON-net

\section{methode}

broedzegen

broedzegen

broedzegen

broedzegen

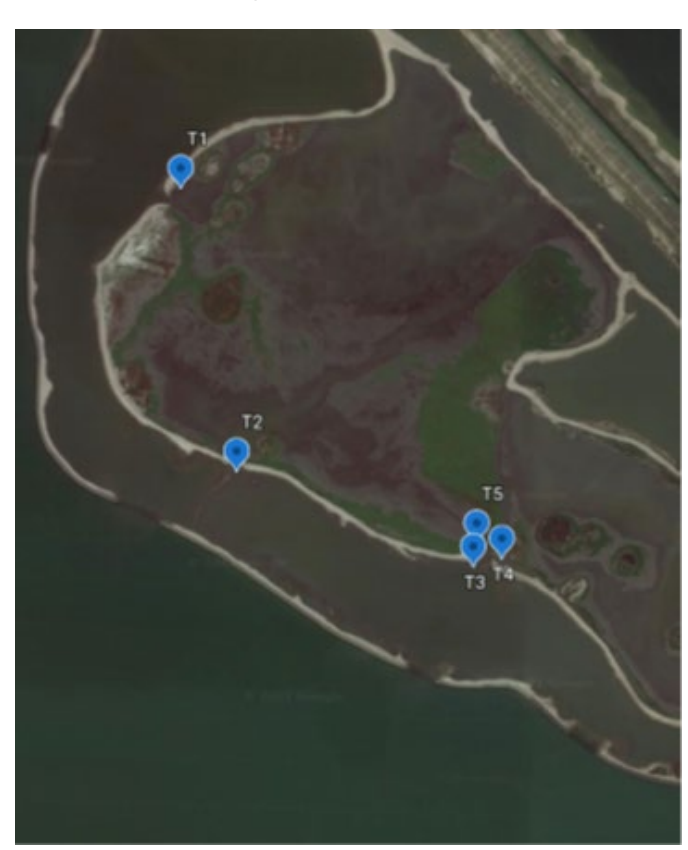

De locatiekeuze werd ter plekke bepaald op basis van een inschatting van waar vislarven zich redelijkerwijs zouden kunnen verzamelen. Uit ervaringen op Marker Wadden zijn dat met name mondingen van ondiepe vegetatierijke gebieden. Afhankelijk van de windrichting wordt water in het oostelijk Markermeer opgestuwd (westenwind) of juist niet. Door deze windgedreven waterniveauverschillen ontstaan waterbewegingen het ondiepe moeras in en uit, waardoor ondiepe geulen ontstaan. Op Trintelzand gaat het om de openingen ten westen en zuiden van de binnendelta, inclusief de gegraven geul aan de zuidzijde. Door drijfzand was het op veel plaatsen niet mogelijk bemonsteringen wadend uit te voeren en door ondieptes waren gebieden ook met een boot nauwelijks toegankelijk. De bemonsterde locaties zijn plekken waar jonge vis zich kan verzamelen. De bemonsteringsmethodiek is niet exact kwantitatief. De lengte van een zegentrek of traject dat met een RAVON-net werd bevist werd beperkt tot enige tientallen meters, tot maximaal $50 \mathrm{~m}$ in de zuidelijke geul. Omdat de verschillende locaties niet op vergelijkbare wijze konden worden bevist is de cpue (aantallen aangetroffen in een trek) niet gecorrigeerd voor een schatting van bevist oppervlak, maar geven de aantallen de werkelijk gevangen aantallen in die trek weer (Figuur B5.2). De meeste larven waren ca 2-5 cm en werden indien noodzakelijk in het lab met een binoculair op soort gedetermineerd (onder meer op basis van tellingen van het aantal vinstralen). 
Er werden 9 verschillende soorten aangetroffen, vooral baars en snoekbaars en in de geulen bij de zuidelijke monding ook winde. Daarnaast werden in kleine aantallen alver, blankvoorn, pos, driedoornige stekelbaars, Pontische stroomgrondel en zwartbekgrondel gevonden.

\section{Trintelzand}

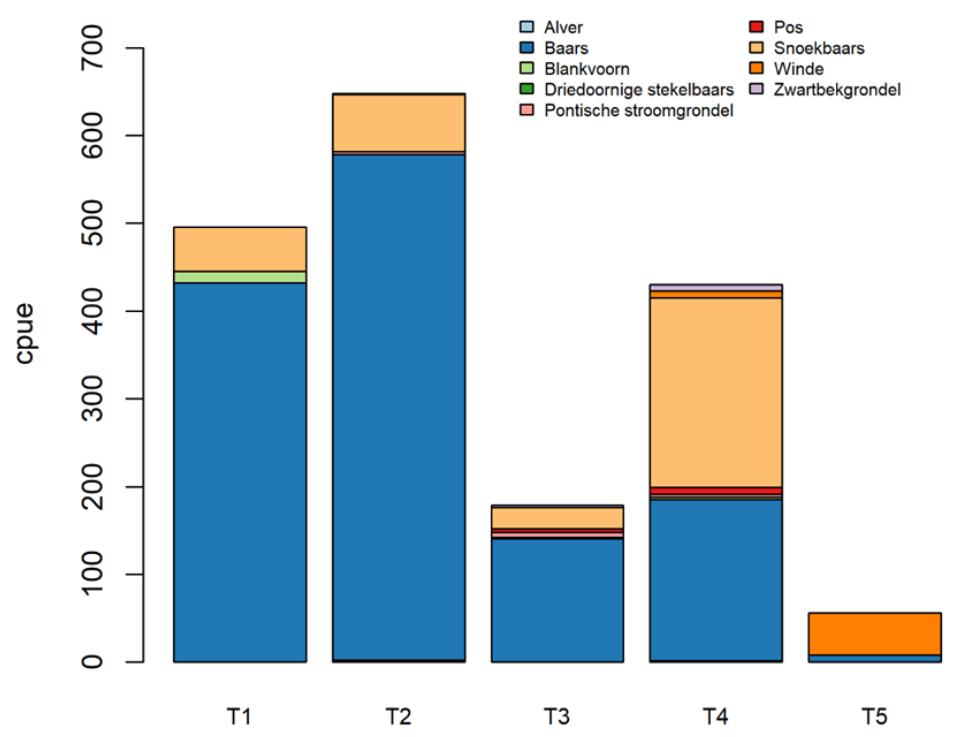

Figuur B5.2. Vangsten jonge vis (cpue, aantal per trek) op Trintelzand op 16 juni 2020. 
T: +31(0)317480900

E: marine-research@wur.nl

www.wur.nl/marine-research

Bezoekers adres:

- Ankerpark 271781 AG Den Helder

- Korringaweg 7, 4401 NT Yerseke

- Haringkade 1, 1976 CP IJmuiden
Wageningen Marine Research levert

met kennis, onafhankelijk

wetenschappelijk onderzoek en advies een wezenlijke bijdrage aan een duurzamer, zorgvuldiger beheer, gebruik en bescherming van de natuurlijke rijkdommen in zee-, kust- en zoetwatergebieden.
Wageningen Marine Research is onderdeel van Wageningen University \& Research. Wageningen University \& Research is het samenwerkingsverband tussen Wageningen University en Stichting Wageningen Research en heeft als missie: 'To explore the potential of nature to improve the quality of life' 